UNIVERSIDADE DE BRASÍLIA

FACULDADE DE CIÊNCIAS DA SAÚDE

PROGRAMA DE PÓS-GRADUAÇÃO EM CIÊNCIAS DA SAÚDE

\title{
Formação em bioética: uma análise de cursos de pós-graduação lato sensu no Brasil.
}

Tese defendida como requisito parcial para obtenção do Grau de Doutor junto ao Programa de Pós-Graduação em Ciências da Saúde da Faculdade de Ciências da Saúde da Universidade de Brasília.

Aluno: Fabiano Maluf

Orientador: Prof. Dr. Volnei Garrafa

Brasília - DF

2015 


\title{
Formação em bioética: uma análise de cursos de pós-graduação lato sensu no Brasil.
}

Tese apresentada por FABIANO MALUF, para análise e avaliação em Defesa de Doutorado, como requisito parcial para obtenção do Grau de Doutor junto ao Programa de Pós-Graduação em Ciências da Saúde da Faculdade de Ciências da Saúde da Universidade de Brasília.

\author{
Banca examinadora: \\ Prof. Dr. Volnei Garrafa \\ Presidente da Banca \\ Departamento de Saúde Coletiva - FS/UnB \\ Cátedra Unesco de Bioética \\ Profa. Dra. Lílian Marly de Paula \\ Departamento de Odontologia - FS/UnB \\ Membro \\ Prof. Dr. Carlos Gramani Guedes \\ Departamento de Odontologia - FS/UnB \\ Membro \\ Profa. Dra. Mirelle Finkler \\ Departamento de Odontologia - UFSC \\ Membro \\ Prof. Dr. José Francisco Nogueira Paranaguá de Santana \\ Fundação Oswaldo Cruz - Nethis/Fiocruz \\ Membro \\ Prof. Dr. Natan Monsores de Sá \\ Departamento de Saúde Coletiva - FS/UnB \\ Membro Suplente


Para meus filhos Ana Luiza e André 


\section{AGRADECIMENTOS}

A Deus, pelo dom da vida;

A meus pais Sérgio (in memorian) e Luzia, pelos exemplos de retidão e sabedoria;

A minha esposa Betanea, pelo incentivo e compreensão;

A meus filhos Ana Luiza e André, pelos ensinamentos diários;

A meus irmãos, Frederico e Sérgio Jr. pelo apoio;

Ao Professor Volnei Garrafa, pela confiança e oportunidade, a minha mais profunda gratidão, admiração e respeito;

Ao Professor José Carlos Abellán Salort da Universidad Rey Juan Carlos, por ter me aceito em Madrid, pelos ensinamentos e oportunidades de aprendizagem;

Ao Professor João Geraldo Bugarin Jr, pela amizade construída ao longo dos anos;

Aos colegas de Máster 2013/2014 na URJC, pela acolhida e pelos agradáveis momentos de convivência;

A Capes, pelo financiamento do Estágio de Doutorado no Exterior e ao Programa de Pós-Graduação em Ciências da Saúde da UnB pela colaboração na obtenção da bolsa;

A Vanessa de Santana Sertão e Camila Guedes da Cátedra Unesco de Bioética;

Aos colegas de bioética da UnB, as "amizades tardias" conquistadas durante os anos de convivência e estudo;

Aos Coordenadores dos cursos de especialização em bioética entrevistados, pela colaboração e contribuição para a realização deste trabalho. 
"Feliz aquele que transfere o que sabe e aprende o que ensina."

Cora Coralina 


\section{SUMÁRIO}

LISTA DE ABREVIATURAS ….................................................................... vii

LISTA DE TABELAS............................................................................... ix

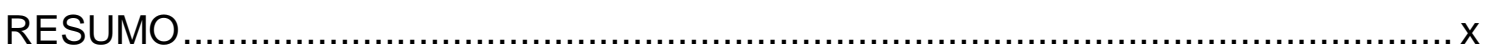

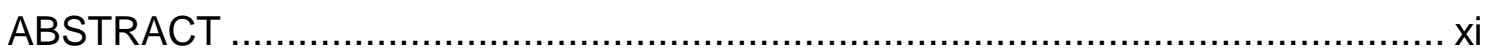

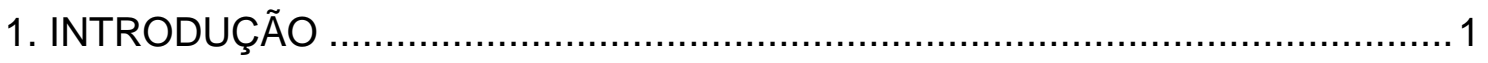

2. REVISÃO DE LITERATURA.............................................................. 3

2.1. A formação ética dos profissionais de saúde frente aos novos avanços e

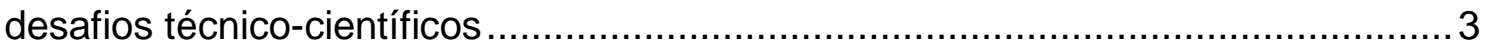

2.2. O ensino da Bioética no Brasil ...................................................................... 8

2.3. Alguns problemas e dúvidas no campo da educação em Bioética ................. 15

2.4. O ensino da bioética no contexto da pós-graduação lato sensu: o panorama

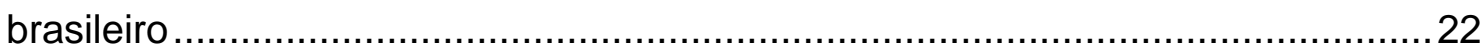

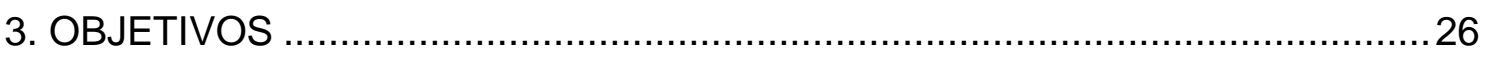

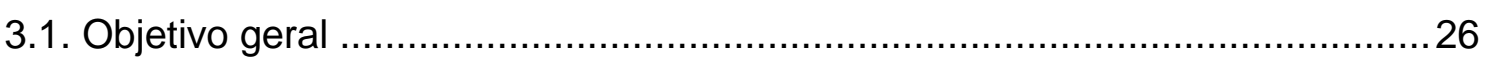

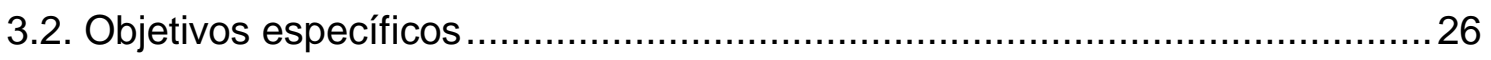

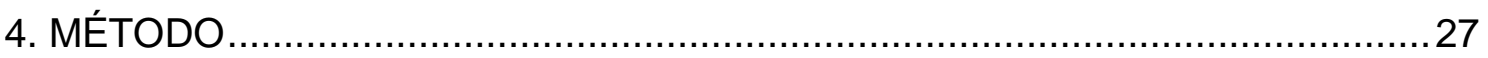

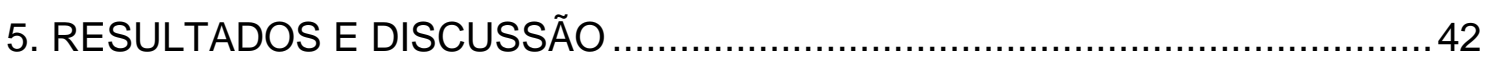

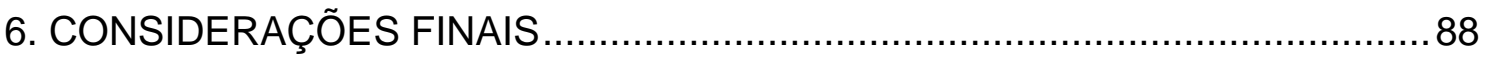

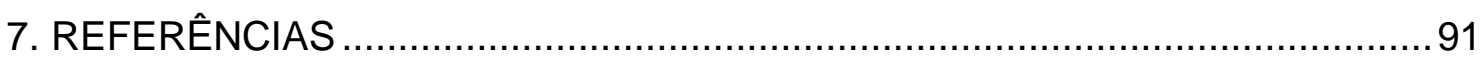

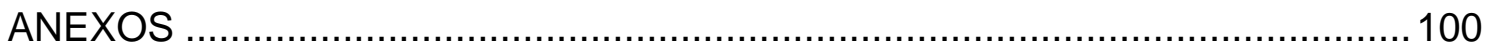

ANEXO 1 - Resolução CNE/CES № 01 de 08 de junho de 2007 .........................101

ANEXO 2 - Instrumento Para Coleta de Dados ................................................... 102

ANEXO 3 - Termo de Consentimento Livre e Esclarecido ..................................... 105

ANEXO 4 - Parecer de Aprovação do Comitê de Ética em Pesquisa .................... 107

ANEXO 5 - Resolução CNE/CES № 02 de 12 de fevereiro de 2014 .................... 108 


\section{LISTA DE ABREVIATURAS}

Capes - Coordenação de Aperfeiçoamento de Pessoal de Nível Superior

CEAM - Centro de Estudos Avançados Multidisciplinares

CEP - Comitê de Ética em Pesquisa

CES - Câmara de Educação Superior

CFM - Conselho Federal de Medicina

CNBB - Confederação Nacional dos Bispos do Brasil

CNE - Conselho Nacional de Educação

CNPq - Conselho Nacional de Desenvolvimento Científico e Tecnológico

CNS - Conselho Nacional de Saúde

CONEP - Comissão Nacional de Ética em Pesquisa

DCN - Diretrizes Curriculares Nacionais

DSC - Departamento de Saúde Coletiva

DUBDH - Declaração Universal sobre Bioética e Direitos Humanos

EAD - Ensino à Distância

Fiocruz - Fundação Oswaldo Cruz

HCPA - Hospital de Clínicas de Porto Alegre

IFF - Instituto Fernandes Figueira

MEC - Ministério de Educação

NEB - Núcleo de Estudos em Bioética

NEPeB - Núcleo de Estudos e Pesquisa em Bioética

NESP - Núcleo de Estudos em Saúde Pública

PUC-PR - Pontifícia Universidade Católica do Paraná

PUC-RS - Pontifícia Universidade Católica do Rio Grande do Sul

RBB - Revista Brasileira de Bioética

SBB - Sociedade Brasileira de Bioética

SUS - Sistema Único de Saúde

TCLE - Termo de Consentimento Livre e Esclarecido

UEL - Universidade Estadual de Londrina

UFRGS - Universidade Federal do Rio Grande do Sul

UnB - Universidade de Brasília 
Unesco - Organização das Nações Unidas para a Educação, a Ciência e a Cultura

Unisinos - Universidade do Vale do Rio dos Sinos

USP - Universidade de São Paulo 


\section{LISTA DE TABELAS}

TABELA 1 - DISTRIBUIÇÃO DAS DISCIPLINAS DO CURSO OFERECIDO PELO CENTRO UNIVERSITÁRIO SÃO CAMILO POR UNIDADES DE APRENDIZAGEM E UNIDADES TEMÁTICAS DE ACORDO COM AS LINHAS DE PESQUISA

TABELA 2 - DISTRIBUIÇÃO DAS DISCIPLINAS DO CURSO OFERECIDO PELA PUC-PR POR UNIDADES DE APRENDIZAGEM E UNIDADES TEMÁTICAS DE ACORDO COM AS LINHAS DE PESQUISA

TABELA 3 - DISTRIBUIÇÃO DAS DISCIPLINAS DO CURSO OFERECIDO PELA PUC-RS POR UNIDADES DE APRENDIZAGEM E UNIDADES TEMÁTICAS DE ACORDO COM AS LINHAS DE PESQUISA

TABELA 4 - DISTRIBUIÇÃO DAS DISCIPLINAS DO CURSO OFERECIDO PELO INSTITUTO FERNANDES FIGUEIRA POR UNIDADES DE APRENDIZAGEM E UNIDADES TEMÁTICAS DE ACORDO COM AS LINHAS DE PESQUISA

TABELA 5 - DISTRIBUIÇÃO DAS DISCIPLINAS DO CURSO OFERECIDO PELO INSTITUTO OSCAR FREIRE POR UNIDADES DE APRENDIZAGEM E UNIDADES TEMÁTICAS DE ACORDO COM AS LINHAS DE PESQUISA 50

TABELA 6 - DISTRIBUIÇÃO DAS DISCIPLINAS DO CURSO OFERECIDO PELA UNIVERSIDADE ESTADUAL DE LONDRINA POR UNIDADES DE APRENDIZAGEM E UNIDADES TEMÁTICAS DE ACORDO COM AS LINHAS DE PESQUISA 


\section{RESUMO}

Introdução: O presente trabalho apresenta uma análise do perfil acadêmico de cursos de pós-graduação lato sensu em bioética oferecidos no Brasil. Objetivo: Descrever o panorama de seis cursos de especialização em bioética oferecidos com mais regularidade no país e realizar uma análise comparativa entre eles e o curso de especialização em bioética da Universidade de Brasília. Método: Foram realizadas análise documentais das ementas dos cursos selecionados com a finalidade de obter dados sobre o conteúdo programático preferencialmente adotado; sobre os objetivos e métodos utilizados no processo de ensino-aprendizagem; sobre a formação acadêmica dos docentes e propor um roteiro de exigências mínimas para abertura e funcionamento de cursos de pós-graduação lato sensu em bioética. Foram realizadas também entrevistas semi-estruturadas com os coordenadores dos cursos. Os resultados encontrados foram submetidos à análise qualitativa pela Análise de Conteúdo, proposta por Bardin. Resultados: Os resultados indicam que os cursos têm em comum o objetivo de proporcionar uma visão integradora da bioética com o intuito de despertar o interesse dos profissionais para a reflexão e o debate de problemas bioéticos. Entretanto, percebe-se uma acentuada predominância do principialismo como fundamentação da discussão, restrita ao campo biomédico nos cursos analisados, contrastando com a Declaração Universal sobre Bioética e Direitos Humanos, adotada como referencial teórico pelo curso de especialização da Universidade de Brasília, o que permite uma ampliação conceitual da bioética mais próxima da realidade e do contexto dos macroproblemas brasileiros e latinoamericanos.

Palavras-chave: Ensino da bioética; educação em bioética; pós-graduação. 


\begin{abstract}
Introduction: This study presents an analysis of the academic profile of "lato sensu" bioethics Postgraduate courses in Brazil. Objective: to describe the panorama of the six most regularly offered "lato sensu" bioethics Postgraduate courses in the country and to carry out a comparative analysis among them and the "lato sensu" bioethics post-graduation course offered at the University of Brasilia. Methods: A documental analysis of selected syllabi was made in order to obtain data on the preferred contents when constructing the curriculum, on objectives and on methods used in the teaching-learning process, and on academic training of teachers; furthermore, in pursuance of proposing a roadmap of minimum requirements for opening and operating "lato sensu" bioethics Postgraduate courses. Semi-structured interviews with the coordinators of the courses were conducted. Results were analyzed using the content analysis proposed by Bardin. Results: The results indicate that the courses share a common objective: providing an integrated view of bioethics in order to arouse the interest of professionals to reflect and debate on bioethical issues. Nevertheless, a remarkable predominance of principlism as the basis of discussion, restricted to the biomedical field, was observed. This finding contrasted with the adoption, by the "lato sensu" bioethics post-graduation course offered at the University of Brasilia, of the Universal Declaration on Bioethics and Human Rights as a theoretical framework that allows a conceptual expansion of bioethics, making it closer to reality and to the context related to Brazilian and Latin American macro-problems.
\end{abstract}

Keywords: Teaching in bioethics; education in bioethics; postgraduate. 


\section{INTRODUÇÃO}

Com o acelerado progresso da ciência, sobretudo a partir de meados do século $X X$, implantou-se um modelo de ensino que privilegiava a formação científica de alto nível. Apesar dos avanços terem contribuído para o reconhecimento social da medicina e das demais profissões da área da saúde, também colaborou para o distanciamento entre a formação técnico-científica e a ético-humanística.

Muitos autores criticam que a ênfase dada a este modelo de ensino não acompanhou a reflexão necessária à resolução das questões éticas e, portanto, morais que surgiram com os avanços do conhecimento na área da biomedicina ${ }^{1,2,3,4,5}$.

Desse modo, a preocupação de se levar em conta também o conteúdo ético se torna cada vez mais necessária. Apesar da formação técnico-científica ser imprescindível para o embasamento teórico da prática profissional, exige-se hoje uma educação que vá além do conhecimento teórico ${ }^{6}$.

Atualmente é importante que o profissional tenha uma visão globalizada dos problemas ético-morais e sociais da era contemporânea, alicerçada em bases ético-filosóficas e legais. Para atingir esse objetivo se faz necessário promover o desenvolvimento de novas competências relacionadas com as questões éticas envolvidas na vida profissional ${ }^{7,8,9,10}$.

Diante dos avanços alcançados pelo conhecimento científico e da limitada reflexão ética para acompanhá-los, surge o neologismo bioética, no início dos anos 1970. Desponta como uma reação da sociedade ao progressivo crescimento do poder das tecnologias sobre o homem, onde "bio" representa os conhecimentos biológicos, ou seja, a ciência dos sistemas viventes; e "ética" representa o conhecimento dos sistemas de valores humanos ${ }^{11}$.

O enfoque deontológico, restrito a um conjunto de normas e códigos trabalhados de forma descontextualizada ${ }^{12}$ e pautado basicamente em deveres perfeitos e imperfeitos, tem se mostrado insuficiente para atender as necessidades da formação ética dos profissionais de saúde na atualidade ${ }^{13}$.

De acordo com Aires e cols. ${ }^{14}$, o paradigma da ética tradicional é inviável para oferecer soluções diante das novas situações apresentadas pelo 
contínuo desenvolvimento científico e os problemas resultantes deles. Dessa forma, a reflexão, a filosofia e o juízo de valores humanos se fragilizaram.

Em virtude desta fragilidade e "insuficiência ética", o interesse pela bioética tem despertado nas mais diversas áreas de atuação, principalmente nas ciências da saúde.

Este despertar tem-se traduzido na crescente oferta e procura por cursos de extensão ${ }^{15}$ e programas de pós-graduação lato sensu e stricto sensu em bioética no Brasil ${ }^{7}$, assim como na inserção da bioética como disciplina autônoma em cursos de graduação ${ }^{16,17,18}$.

Devido à ausência de informações precisas acerca da expansão dos cursos de pós-graduação lato sensu em bioética oferecidos desde a implantação da disciplina no Brasil visto que cursos de especialização independem de autorização, reconhecimento e renovação de reconhecimento do Ministério de Educação (MEC) ${ }^{19}$, teve-se como propósito realizar um estudo ampliado sobre esta realidade.

Nesse sentido, a presente pesquisa se propõe como objetivo desenvolver um levantamento sobre os cursos em funcionamento no país, descrevendo e analisando criticamente sua estrutura, os conteúdos programáticos abordados, a formação dos docentes envolvidos, o histórico e o desenvolvimento, sua periodicidade, o perfil acadêmico dos alunos e o modelo de ensino-aprendizagem, comparando os dados obtidos com aqueles informados pelo curso mais tradicional do país oferecido regularmente pela Universidade de Brasília (UnB) desde 1998, atualmente, em sua 17aㅡ versão anual.

Posteriormente, a síntese desses dados será submetida a comentários críticos de acordo com as bases teóricas de referência do estudo. Após a análise dos dados é objetivo do presente estudo propor um roteiro a ser apresentado à Sociedade Brasileira de Bioética com vistas a um futuro encaminhamento ao Ministério de Educação de recomendações mínimas para abertura e funcionamento de novos cursos na modalidade de pós-graduação lato sensu em bioética no Brasil. 


\section{REVISÃO DE LITERATURA}

\subsection{A formação ética dos profissionais de saúde frente aos novos avanços e desafios técnico-científicos}

O caráter eminentemente técnico na formação dos profissionais das ciências da saúde tem raízes nas recomendações do relatório Flexner do início do século $X X^{20}$. Sua característica impõe a fragmentação dos saberes e indica como referências a matriz hospitalocêntrica, o biologicismo, a especialização precoce e a tecnificação do ato clínico, ou seja, uma formação prioritariamente técnica em detrimento de características humanísticas também desejáveis ${ }^{1,4,5}$.

Esta abordagem tem se mostrado defasada para interpretar adequadamente a realidade atual, reduzindo os espaços de discussão sobre valores e moralidades inerentes às práticas sanitárias, discussões estas reivindicadas devido às constantes transformações pelas quais passam as relações entre os indivíduos, os grupos e a sociedade ${ }^{2}$.

Paralelamente a este enfoque tecnicista, fragmentado e desarticulado, a formação e o ensino da ética profissional nas áreas da saúde tem se restringido aos aspectos deontológicos e legais, sem correlação com uma abordagem holística do paciente ${ }^{3,4}$. Ocorre que a deontologia pode ser entendida como o estudo dos deveres dos profissionais tendo como base um marco ético e jurídico - os códigos de ética - e, portanto, insatisfatório para formar profissionais contextualizados com os problemas éticos relacionados com os avanços tecnológicos, com as demandas sociais contemporâneas e com o próprio quadro atual da saúde no país ${ }^{7}$.

Rego e cols. ${ }^{21}$, ao discutirem a formação moral nos cursos de graduação em saúde, afirmam que os códigos de ética profissional contêm normas com o intuito de estabelecer padrões de comportamento corporativo a ser seguido por seus pares.

Estudo realizado por Kottow ${ }^{22}$ concluiu que no decorrer da graduação instalava-se "uma progressiva erosão de atitudes humanistas", substituída por uma orientação profissional mais voltada para o cumprimento de normas e códigos. 
Para Siqueira $^{13}$, o modelo tradicional de ensino da ética por meio da disciplina de medicina legal e deontologia mostrou-se defasado para responder aos conflitos morais oriundos dos avanços da ciência, em particular as novas e recentes tecnologias aplicadas à área biomédica. Para o autor, esta lacuna limita a completa formação humanista do médico ${ }^{13}$.

Em estudo para análise bioética do código de ética odontológico brasileiro, Pyrrho e cols. ${ }^{23}$ concluíram que o referido código sustenta-se em condutas corporativistas e legalistas, com predomínio de itens técnicos e legais, e na valorização das virtudes relacionadas ao próprio cirurgião dentista. Além de criticar o fato do código de ética da odontologia centrar atenção na figura do próprio profissional ao invés de enfocar centralmente o paciente sujeito óbvio do processo da atenção profissional - os autores apontam a bioética como possibilidade de oferecer um instrumento mais adequado à contemporaneidade das sociedades plurais pós-modernas.

Nessa perspectiva, Amorim ${ }^{24}$, ao analisar a formação de cirurgiões dentistas, enfatiza a necessidade de reflexões fundamentadas nos princípios de justiça, responsabilidade, respeito e solidariedade em oposição a uma "formação ética" estritamente pautada no estudo do código de ética odontológico. A autora conclui que, ao se restringir a abordagem apenas aos aspectos deontológicos, falta ao ensino da ética 0 caráter da transdisciplinaridade em oposição à concepção normativa presente na formação do odontólogo ${ }^{24}$.

Segundo Pessalacia e cols. ${ }^{8}$, o ensino da ética nos cursos de enfermagem no Brasil não deve ficar restrito a uma orientação prescritiva e normativa incapaz de proporcionar aos discentes atitudes autônomas voltadas para uma prática profissional crítica e reflexiva.

Orientações semelhantes foram ratificadas por Mascarenhas e SantaRosa $^{12}$ ao relatarem que o ensino da ética nas escolas de enfermagem tem se caracterizado por uma visão deontológica, insuficiente no processo de formação do enfermeiro. Afirmam que o contexto atual exige do profissional um perfil que requer o desenvolvimento de competência política e social, de modo a estimular discussões de forma crítica e articulada aos dilemas emergentes da prática cotidiana ${ }^{12}$. 
O fato da inclusão de questões deontológicas relacionadas às práticas profissionais não ser considerado 'matéria ética', caso seja destituída de uma visão crítica capaz de questionar posicionamentos e argumentos, indicam tão somente o cumprimento de uma obrigação formal justificada para a atuação profissional $^{25}$.

Ao guiarem sua atuação somente de acordo com os preceitos de um código de ética, os profissionais se privam da crítica e autocrítica tão requeridas para o questionamento de suas próprias posições e argumentos, assim como suas relações com valores e modelos de prática ${ }^{23}$. Muitos autores concordam que a formação ética dos profissionais de saúde tem sido pouco estudada e até mesmo banalizada nas propostas de formação acadêmica ${ }^{9,18,25}$.

A formação profissional não pode se restringir ao conhecimento deontológico - necessário, é verdade, mas incorporar modelos de aprendizagem que permitam o desenvolvimento moral como pessoa, tanto na dimensão individual como social e coletiva ${ }^{26}$.

Entretanto, contrapondo-se a este modelo cartesiano de ensino, novas perspectivas começam a surgir com a finalidade de resgatar uma formação ética mais adequada e de acordo com o desenvolvimento de uma postura mais humanista, crítica e reflexiva, voltada para a integralidade das ações em saúde.

A proposta atual é de que se formem profissionais que sejam capazes de acompanhar a complexidade da conjuntura do mercado de trabalho, das diretrizes das políticas públicas de saúde e da evolução dos conhecimentos científicos acerca do processo saúde-doença ${ }^{1}$. Cezar e cols. ${ }^{3}$ sustentam que o graduando deva estar envolvido em atividades ligadas à promoção, à prevenção, à reabilitação e à recuperação da saúde.

Nesse contexto, o ensino da bioética desponta como uma possibilidade de inovação curricular nos cursos de graduação em ciências da saúde como alternativa ao modelo prescritivo e normativo.

Autores como Finkler e cols. ${ }^{9}$, afirmam que a inserção da ética na estrutura curricular por meio do ensino da bioética tem sido um tema de interesse crescente no meio acadêmico. Informações semelhantes foram divulgadas por Oliveira e cols. ${ }^{27}$ ao afirmarem que a disciplina bioética começa a ser incluída nos currículos em diversas áreas acadêmicas. 
Em outro artigo, Mascarenhas e Santa-Rosa ${ }^{7}$ relatam que a introdução dos conteúdos de bioética nos currículos de formação dos profissionais de saúde é capaz de provocar mudanças na formação ético-moral dos alunos de modo a transpor discussões na academia que se limitavam apenas aos aspectos deontológicos e normativos da profissão.

O ensino da bioética, como ética prática e aplicada à ação, deve proporcionar ao estudante condições teóricas e práticas suficientes para 0 desenvolvimento da competência moral, principalmente no que diz respeito à inclusão dos aspectos humanísticos e reconhecidamente essenciais à formação profissional ${ }^{2}$.

Estudo realizado na Universidade Estadual de Londrina ${ }^{28}$ com o objetivo de comparar a importância, o grau de aceitação e/ou rejeição entre as disciplinas de medicina legal e bioética na formação profissional do médico resultou em índice de aprovação expressivamente superior desta última em relação à primeira.

Os achados anteriores são corroborados por Prado e Garrafa ${ }^{29} \mathrm{em}$ estudo realizado com o objetivo de analisar se o ensino da bioética, como disciplina de reflexão, representa um diferencial atitudinal na formação em odontologia. Os autores concluem que a incorporação dos fundamentos teóricos e práticos da bioética é de fundamental importância para a formação do profissional de saúde por favorecer a compreensão da realidade numa perspectiva consciente, crítica e interdisciplinar ${ }^{29}$.

A importância da bioética para a formação dos profissionais de saúde é também evidenciada nas Diretrizes Curriculares Nacionais (DCN) ao enfatizar abordagens que permitam aos estudantes o desenvolvimento de competências para a atenção e cuidado à saúde ${ }^{30,31,32}$.

No entanto, um paradoxo se estabelece com a constatação de que a formação ética profissional fundamentada em aspectos deontológicos, códigos de ética, normas e prescrições jurídicas é insuficiente para uma formação integral e humana. O paradoxo aparece ao se constatar que a resposta dada ao se propor a adoção da bioética como alternativa viável é muito frágil, pois conta ainda com uma pequena valorização da disciplina, conforme mencionam diferentes autores ${ }^{5,10,18,30,33,34,35}$. 
Ratificando a afirmativa anterior, Finkler e cols. ${ }^{18}$ ao estudarem a dimensão ética da formação profissional em cursos de graduação em odontologia demonstraram uma pequena valorização da bioética por parte das faculdades e atestam sua ausência como tema transversal curricular em conjunto com escassa formação bioética dos docentes.

Nessa mesma linha de raciocínio, estudo realizado por Almeida e cols. ${ }^{35}$ atesta que professores, médicos e estudantes de medicina consideram a disciplina bioética importante, apesar das evidências de baixo interesse, atualização e conhecimento. Os autores salientam que o ensino em apenas um semestre parece ter pouco efeito na formação dos estudantes ${ }^{35}$.

Caramico e cols. ${ }^{5}$ afirmam que o ensino da bioética nas faculdades de medicina no Brasil necessita da construção de uma identidade própria com o objetivo de superar uma série de peculiaridades advindas do modelo tradicional de ensino-aprendizagem. Identificam também o número reduzido de professores de bioética com preparo adequado.

Interessantes foram os achados de Oliveira e cols. ${ }^{34}$ ao avaliarem o ensino de bioética nas faculdades de medicina do estado de São Paulo no qual $57 \%$ dos alunos não souberam distinguir bioética de deontologia médica. Concluíram que exposições sob a forma de aulas teóricas podem ser as responsáveis pelo grande desinteresse dos alunos pela disciplina.

Em um estudo mais recente, Zanatta e Boemer ${ }^{33}$ concluíram que o ensino da bioética nos cursos de graduação em enfermagem em uma região do estado de São Paulo é incipiente, evidenciando uma carência por parte dos alunos no lidar com os problemas de natureza bioética.

Dessa forma, percebe-se que o discurso não tem se efetivado na prática, haja vista que não houve nas últimas décadas um crescimento significativo no número de disciplinas dedicadas exclusivamente à bioética, nem de docentes com funções específicas em bioética, denotando um pequeno envolvimento institucional no fortalecimento do ensino e pesquisa na área ${ }^{10}$.

Estudo realizado por Puplaksis e cols. ${ }^{36}$ identificou uma abordagem muito teórica da bioética e a ausência de temas relacionados com a aplicação prática de valores em relação a casos concretos. Os autores concluem que até então prevalece o aprendizado técnico e a conduta paternalista de professores e alunos, e questionam o melhor momento para se ministrar a disciplina, a 
abrangência e a aplicabilidade prática ao longo de todo o curso. Afirmam que a bioética, como disciplina isolada, é incapaz de prover as mudanças almejadas e propõem a sintonia entre a estrutura física e humana da universidade com um mesmo quadro de valores e condutas ${ }^{36}$.

Finkler ${ }^{37}$ enfatiza que a instituição universitária deve compreender que a "formação ética" não está relacionada somente às boas intenções, mas também à efetividade e excelência, no qual conceitos como cidadania, ética, moral e valores devem ocupar papel de destaque no processo de formação dos futuros profissionais.

É importante ressaltar a fala de Martínez e cols. ${ }^{38}$ ao afirmarem que o tratamento pedagógico da ética não pode ser restrito a modificações curriculares ou à incorporação de uma nova disciplina, mas requer uma transformação de perspectiva acerca do que representa um bom nível de formação profissional e sobre o que deve significar o compromisso de uma instituição que pretenda formar bons profissionais e cidadãos participantes. Concluem que somente com mudanças na cultura docente e na instituição universitária que a integração da ética será possível ${ }^{38}$.

Para concluir, a criação e a manutenção de espaços de reflexão e discussão em cada instituição se faz premente para que as novas propostas não se restrinjam ao nível retórico, mas constituam um ponto de partida viável para mudanças concretas na formação ética dos profissionais de saúde ${ }^{9}$.

\subsection{O ensino da Bioética no Brasil}

No Brasil, a bioética teve um desenvolvimento tardio ${ }^{39}$. É oportuno resgatar o processo histórico de criação de seus espaços de discussão no país. Três fatos marcantes contribuíram para a sua consolidação junto à comunidade científica brasileira ${ }^{30,40}$.

Primeiro, a iniciativa do Conselho Federal de Medicina (CFM) em editar, a partir de 1993, a revista Bioética, um periódico científico com a finalidade de divulgar o pensamento e a produção acadêmica nacional na área. Em 2012 o periódico completou vinte anos de circulação num percurso de intensa e frutífera troca intelectual a favor de um país mais ético ${ }^{41}$. 
Segundo, a ampliação do interesse pelo campo da bioética é evidenciada e passa pela atuação da Sociedade Brasileira de Bioética (SBB), que desde a sua criação em 1995, tem promovido regularmente, de dois em dois anos, o Congresso Brasileiro de Bioética, que atualmente se encontra em sua $11^{\underline{a}}$ edição. Com sede em Brasília, a entidade conta, entre seus associados, com pessoas de diferentes áreas acadêmicas interessadas em bioética e é também responsável pela edição da Revista Brasileira de Bioética (RBB) ${ }^{30}$.

Por último, a Resolução 196/96, editada em 1996 pelo Conselho Nacional de Saúde (CNS), aperfeiçoou o controle social sobre as práticas científicas por meio do papel desempenhado pelos Comitês de Ética em Pesquisa (CEP) e pela Comissão Nacional de Ética em Pesquisa (CONEP), nacionalmente conhecidos como Sistema CEP/CONEP ${ }^{42}$. Com mais de 600 CEP espalhados pelo país, seus membros têm dentre suas atribuições à discussão bioética como rotina. Recentemente, após quinze anos de sua publicação, a Resolução 196/96 passou por um processo de revisão e consulta pública, com 0 intuito de agregar novos valores e perspectivas de entendimento, dando origem à Resolução 466/12.

Essas três iniciativas configuram espaços multidisciplinares, plurais e laicos, características essencialmente preconizadas pela bioética, e surgem num período de importante transição paradigmática em âmbito internacional ${ }^{43}$ em oposição à importação acrítica e descontextualizada de pacotes éticos forâneos ${ }^{44}$, sobretudo a hegemonia da teoria principialista, ratificando a necessidade de uma proposta ética alinhada ao contexto brasileiro.

Tal transição paradigmática ${ }^{45,46}$ tem como característica marcante a passagem de uma bioética estritamente individual, com forte predomínio nos dilemas éticos resultantes de ações pessoais do tipo pesquisador versus sujeito de pesquisa, para uma bioética pública, mais direcionada para a dimensão coletiva dos desafios de saúde pública, como também para os desafios ecológico-ambientais.

Segundo Garrafa e Pessini ${ }^{47}$, a partir de 1998, o referencial internacionalmente aceito para a bioética, resgatando a intuição pioneira de Van Rensselaer Potter, passa a ser aquele que se refere à "Bioética Global", no 
qual a ética da qualidade da vida passa a ser estendida a tudo aquilo que se refere à vida humana no seu mais amplo sentido, direta ou indiretamente.

A realização do Sexto Congresso Mundial de Bioética em 2002, em Brasília, com o tema "Bioética, Poder e Injustiça", marca o início da fase adulta $^{40}$ da bioética brasileira e materializa na agenda internacional a inclusão de questões relacionadas às desigualdades e à exclusão social ${ }^{47}$, aspectos antes pouco abordados.

Nas palavras de Garrafa e Pessini ${ }^{47}$,

"o Sexto Congresso Mundial de Bioética plantou em solo fértil a semente de uma bioética politizada. Uma bioética que deixa de ser meramente descritiva ou simplesmente analítica de situações conflitivas, para - sustentada na ética aplicada tornar-se um instrumento concreto para a construção de uma sociedade mais democrática, equânime, solidária e comprometida com transformações sociais verdadeiramente inclusivas" (p. 16).

Mais recentemente esta nova área do conhecimento passou a ser reconhecida como uma nova ciência por alguns estudiosos ${ }^{27}$, a partir do aprofundamento no estudo da construção de uma verdadeira "bioética brasileira", tendo como base a interpretação epistemológica das teorias de Thomas Kuhn. Estes autores destacam como eixo principal para a consolidação desse saber, a discussão e elaboração de um estatuto epistemológico, cujo cerne é o questionamento ontológico da bioética e sua caracterização como campo de conhecimento ${ }^{27}$.

Embora desde a década de 1990 algumas instituições já começavam a inserir a bioética como disciplina, somente a partir de 2001 as novas Diretrizes Curriculares Nacionais dos cursos de graduação na área da saúde ${ }^{30,31,32}$ passaram a reconhecê-la dentre as novas competências e habilidades requeridas na formação dos profissionais de saúde.

Em 2002, Grisard ${ }^{48}$ apresentou dados de dois estudos realizados em 1992 e 2001. Os resultados do primeiro estudo constataram que, do total de 79 cursos de medicina no país, em $90 \%$ deles o ensino da ética não constava como disciplina autônoma, ao passo que o segundo estudo demonstrou que $47,62 \%$ dos estudantes de uma faculdade particular de medicina sequer conheciam o conceito de bioética. Como desdobramento deste estudo a 
instituição passou a ministrar, desde 2001, conteúdos de bioética de forma transversal ao longo de toda a graduação.

Para se estudar o assunto em maior amplitude e profundidade é aconselhável verificar como o ensino da bioética encontra-se inserido entre as finalidades da educação superior, como foi concebida pelas DCN no campo das ciências da saúde e como a formação e a educação em bioética é preconizada pela Declaração Universal sobre Bioética e Direitos Humanos da Unesco (DUBDH) ${ }^{49}$ considerados os dois legítimos dispositivos legais já disponíveis no Brasil para a sua efetiva implementação.

De acordo com as $\mathrm{DCN}$, a relevância da bioética para a formação dos profissionais de saúde é clara ao priorizar abordagens que permitam aos alunos o desenvolvimento de competências para a atenção e cuidado à saúde ${ }^{3}$ :

Art 4ํ - I - Atenção à saúde: "Os profissionais de saúde devem realizar seus serviços dentro dos mais altos padrões de qualidade e dos princípios da ética/bioética, tendo em conta que a responsabilidade da atenção à saúde não se encerra com o ato técnico, mas, sim, com a resolução do problema de saúde, tanto em nível individual como coletivo" (p. 95).

As DCN contribuem como força legisladora ${ }^{8}$ para a promoção de mudanças nos paradigmas e matrizes curriculares da formação dos profissionais de saúde ${ }^{7}$. Apontam como os futuros profissionais deverão atuar no que se refere ao comportamento moral ${ }^{2}$, transformando-se em agentes de mobilização social ${ }^{8}$.

Espera-se que estas orientações promovam o desenvolvimento de uma postura humanística, crítica e reflexiva dos estudantes capacitando-os a considerar os fatores sociais, psicológicos e ambientais envolvidos no contexto clínico do processo saúde-doença ${ }^{3}$.

Para Finkler e cols. ${ }^{9}$, as DCN indicam o compromisso dos movimentos empenhados por mudanças na formação dos profissionais de saúde, diretamente envolvidos e voltados para os princípios da Reforma Sanitária e do Sistema Único de Saúde (SUS) e podem ser consideradas um avanço importante, porém, não garantem que efetivamente ocorrerão.

Entretanto, apesar dos incentivos para introdução da bioética como disciplina regular nos currículos dos cursos de graduação e de quase duas 
décadas de atividade acadêmica, ainda são escassos os textos e estudos sobre o processo histórico de seu ensino no Brasil $^{34}$, assim como se percebe forte resistência para o abandono das raízes deontológicas tradicionais ${ }^{10,13}$.

Segundo Pessalacia e cols. ${ }^{8}$ o ensino da bioética nas escolas de enfermagem no Brasil tem apresentado abordagens estritamente conceituais e deontológicas, aspecto também já evidenciado por Santiago $^{50}$ ao relatar que o ensino da bioética na enfermagem é transmitido de forma teórica e abstrata, com discussões que privilegiam a visão restrita a normas e códigos carecendo de visão questionadora.

D'Ávila" alerta que "na maioria das vezes, em algumas universidades é dada ênfase apenas à deontologia; em raras oportunidades há conteúdo humanístico e/ou uma disciplina específica de bioética" (p. 53). As afirmações acima corroboram relatos sobre o ensino da bioética nas escolas médicas brasileiras, visto que em muitas delas é ensinada junto com medicina legal, não possuindo espaço próprio para ser ministrada ${ }^{5,10}$.

Zanata e Boemer ${ }^{33}$ ao analisarem a inserção da bioética nos cursos de graduação em enfermagem em uma região do estado de São Paulo evidenciaram que dos sete cursos existentes em quatro instituições diferentes, somente um dos cursos tinha em sua estrutura curricular a bioética como disciplina autônoma.

Resultados semelhantes foram encontrados por Musse e cols. ${ }^{17}$ ao revelarem uma grave lacuna quanto ao ensino da bioética nas faculdades de odontologia no estado de São Paulo, pois do total de 45 cursos analisados em 2006, em apenas quatro cursos (8,8\%) encontraram a existência de disciplinas exclusivas de bioética.

Esses achados são confirmados por Finkler e cols. ${ }^{18}$ ao analisarem como vem sendo desenvolvida a dimensão ética dos estudantes de odontologia em quinze cursos de graduação no Brasil. Os resultados encontrados pelos autores revelaram a presença da bioética como disciplina autônoma em apenas uma faculdade; em sete cursos ela se encontra associada à deontologia e/ou outros conteúdos, e ausente enquanto disciplina em outros sete cursos.

Poucos estudos estenderam a pesquisa em bioética às demais áreas acadêmicas; a maioria ficou direcionada ao ensino e avaliação da ética 
deontológica clássica nos cursos de graduação ${ }^{9}$, e são raros os esforços no sentido de mapear a realidade do ensino no contexto dos cursos de pósgraduação em bioética no Brasil.

Recente estudo de Figueiredo ${ }^{52}$, publicado em 2011, ao analisar 199 programas de pós-graduação da área interdisciplinar e 691 cursos de mestrado e doutorado da área da saúde constatou que na época apenas dois programas (1\%) estavam voltados especificamente à formação de bioeticistas (em 2013 este universo passou para quatro programas), 163 cursos (23,6\%) ofereciam disciplinas de bioética, outros 32 (4,6\%) possuíam módulos de bioética e, em 36 deles $(5,2 \%)$ o ensino era conduzido pela tradição deontológica. Segundo o autor, os resultados evidenciaram que a pós-graduação em bioética no país se encontra em fase de construção, pois em 460 cursos da amostra estudada $(66,6 \%)$ inexistem disciplinas relacionadas com ética ou bioética ${ }^{52}$.

O referido estudo, no entanto, dedicou-se exclusivamente à análise das disciplinas e conteúdos de bioética encontrados nos programas stricto sensu regularmente credenciados pela Coordenação de Aperfeiçoamento de Pessoal de Nível Superior (Capes) na área das ciências biomédicas e da saúde ${ }^{52}$.

Aires e cols. ${ }^{14}$ ao estudarem o ensino da bioética em 87 programas de pós-graduação stricto sensu em odontologia no Brasil encontraram 48 programas com a disciplina ética/bioética presente, sendo que $38 \%$ dos programas com conceitos 5, 6 e 7 da Capes mantêm disciplinas de bioética, enquanto $62 \%$ dos programas com conceitos 3 e 4 apresentaram conteúdos de bioética. Os resultados dos autores mostraram que o ensino da bioética é incipiente nos programas analisados e concluíram que seria necessária uma pedagogia ética na formação do jovem pesquisador ${ }^{14}$.

Dessa forma, pode-se dizer que o ensino da bioética é um desafio para a educação brasileira ${ }^{8}$. Interessa, também, examinar como a disciplina deve ser estruturada e, no caso da pós-graduação, quais os objetivos da formação em bioética.

Em um artigo histórico publicado sobre esse tema, em 1996, intitulado "Promover o ensino de Bioética no mundo", Lenoir ${ }^{53}$ já defendia que esse ensinamento deveria "ser concebido como forma de ensino integral, sendo parte da formação de base dos futuros cidadãos" (p. 66). 
De acordo com Pires e Shimizu ${ }^{54}$, a bioética tem sido trabalhada quase que exclusivamente em instituições de ensino superior com destaque para os cursos nas áreas biomédicas e biotecnológicas. Observa-se também a inserção da disciplina nas residências médicas e nos diferentes cursos de especialização lato sensu ofertados pelo país, todavia, identifica-se uma carência a ser preenchida - nos ensinos fundamental e médio ${ }^{54}$.

Esta constatação contraria o que preconiza o artigo 23 da DUBDH que prescreve a obrigação dos países signatários de apresentar às suas populações (notadamente aos jovens) em todos os níveis educacionais a formação e educação em bioética

“... alcançar uma melhor compreensão das implicações éticas dos avanços científicos e tecnológicos, em especial para os jovens, os Estados devem envidar esforços para promover a formação e educação em bioética em todos os níveis, bem como estimular programas de disseminação de informação e conhecimento sobre bioética" ${ }^{49}$ (p. 11).

Nesse sentido, Silva ${ }^{55}$ ao estudar o ensino da bioética no ensino médio constatou que $90 \%$ dos 106 licenciandos em biologia entrevistados concordavam que as disciplinas de ciências e biologia deveriam ser espaços de promoção de valores ético-morais. O autor identificou fatores como, por exemplo, a necessidade de esclarecimento sobre a diferença entre educação e doutrinação, que inviabilizariam a inserção da bioética no ensino médio. Denuncia também que pouco se tem feito a fim de tematizar ou explicitar valores ético-morais no ensino dessas disciplinas ${ }^{55}$.

Pires e Garrafa ${ }^{6}$ ao analisarem a opinião de professores de escolas públicas e particulares de ensino médio na cidade de Brasília sobre a inclusão da bioética no currículo escolar, constataram que 51\%, do total de entrevistados indicaram a bioética como a disciplina a ser inserida com o intuito de preencher uma lacuna programática detectada. Segundo os autores, um número expressivo dos entrevistados referiu que a atual estrutura e contexto curricular não comporta trabalhar nas salas de aula temas que estimulem o desenvolvimento de valores e atitudes mais humanos e solidários nos alunos ${ }^{6}$.

Assim, de modo mais ou menos intensivo, o ensino de bioética vem sendo gradativamente estudado como proposta a ser incorporada a todos os 
níveis de formação. Provavelmente o grande desafio pedagógico para a bioética como disciplina seja a construção de seus conteúdos, como deve ser estruturada, como ela é definida em termos de domínio das concepções teóricas e seus objetivos. Tais desafios podem ser considerados como os principais desafios a serem ultrapassados, principalmente porque a bioética não é uma disciplina definitiva e consolidada, nem nos seus conteúdos, nem nos seus limites teóricos e muito menos com relação às metodologias utilizadas para seu ensino.

\subsection{Alguns problemas e dúvidas no campo da educação em Bioética}

Para Azevedo 56 , "o fato de a Bioética ser uma área de saber complexa e recente, não existe, para seu ensino, uma tradição pedagógica específica nem uma experiência didática consolidada" (p. 135).

Seja como disciplina científica ou acadêmica, ela não se limita ao fazer pedagógico tradicional, tampouco está delineada em uma fundamentação pragmática baseada em teorias pré-estabelecidas. Trata-se de uma área multi, inter e transdisciplinar ${ }^{57}$ que está estritamente relacionada aos problemas éticos que se desenvolvem paralelamente ao progresso científico e tecnológico concomitantemente em diferentes lugares e culturas em todo o mundo.

Além disso, a bioética difere da visão deontológica justamente por ter como característica a multi, a inter e a transdisciplinaridade, compreendidas do seguinte modo ${ }^{30,57,58}$ :

- multidisciplinaridade: refere-se ao estudo de um objeto de uma mesma e única disciplina por várias disciplinas ao mesmo tempo;

- interdisciplinaridade: diz respeito à transferência de métodos de uma disciplina para outra;

- transdisciplinaridade: refere-se àquilo que está ao mesmo tempo entre as disciplinas, ou seja, entre os limites de suas diferentes fronteiras e tem como um dos seus imperativos a unicidade do conhecimento.

A partir desse entendimento é possível questionar a insuficiência do método cartesiano para compreender a realidade em seus diferentes contextos. Chamam atenção as observações de Silva e Ribeiro ${ }^{2}$ sobre a 
possibilidade da bioética ser ensinada como um tema transversal e qual seria o lugar dessa transversalidade no contexto pedagógico.

É importante distinguir a transversalidade, relativa aos métodos e técnicas de ensino, dos temas transversais, referentes aos conteúdos que perpassam as diferentes disciplinas. Os temas transversais são saberes dinâmicos que, longitudinalmente, atravessam outros saberes convencionais da estrutura curricular².

Para Yamada e Diniz ${ }^{59}$, o ensino da bioética nos centros universitários não deve ficar restrito aos ciclos básicos e sugerem que módulos de educação continuada sejam incorporados ao longo do curso de forma transversal e interdisciplinar.

É oportuno ratificar a proposta do Ministério da Educação em considerar o ensino de ética e bioética como um tema transversal nos projetos pedagógicos dos cursos universitários, de acordo com as recomendações preconizadas nas Diretrizes Curriculares Nacionais ${ }^{1}$.

No entanto, achados diferentes das orientações das DCN são encontrados em muitos artigos. Em estudo realizado na Faculdade de Odontologia da Universidade Federal do Rio Grande do Norte, Amorim ${ }^{24}$ identifica que falta ao ensino da bioética o caráter da transdisciplinaridade, uma vez que esse conteúdo é abordado, a partir do enfoque deontológico, em um único período, no oitavo semestre do curso.

Para Almeida e cols. ${ }^{35} 0$ ensino pontual em apenas um semestre parece ter pouco efeito na formação dos estudantes. Corroborando estas afirmações, em grande parte das faculdades de medicina no Brasil a disciplina bioética é ofertada em um semestre, principalmente no quarto ano da graduação ${ }^{5,24}$.

Rupaya $^{60}$ chama atenção para o desconhecimento, por parte dos docentes de uma tradicional faculdade pública de odontologia no Peru, de conceitos de bioética no desenvolvimento das atividades clínicas e no processo de investigação científica. A autora destaca a ênfase quanto aos aspectos clínicos e a carência de momentos de reflexão crítica acerca da relação profissional-paciente durante o curso. Conclui defendendo a necessidade e importância de se trabalhar conteúdos de ética e bioética no processo de ensino-aprendizagem ao longo de toda a graduação, pois estes conhecimentos 
podem proporcionar uma atitude mais sólida e responsável no exercício profissional $^{60}$.

É interessante registrar os relatos de dois estudos realizados em momentos distintos e que recomendam que o ensino da bioética ocorra ao longo de toda a graduação ${ }^{28,61}$ e se estenda, inclusive, aos cursos de pósgraduação ${ }^{61}$. Entretanto, merece destaque discutir determinados aspectos quando se trata do ensino da bioética como, por exemplo, quem e como ensinar bioética? ? $^{53,35,56}$

Silva e Ribeiro ${ }^{2}$ interrogam como professores marcados pela disciplinaridade tradicional ou até mesmo pela multidisciplinaridade desenvolverão os conteúdos de bioética de forma transversal?

Dessa forma, depara-se com a dificuldade de se contar com a bioética de maneira transversal nas diferentes disciplinas na graduação pelo fato de ainda não se dispor de docentes na área, seja pelo pouco conhecimento conceitual e prático da bioética seja por não se perceberem partícipes no processo de formação ética do aluno ${ }^{17}$.

Figueiredo ${ }^{62}$ ao estudar o perfil dos professores de bioética na pósgraduação no Brasil constatou que $86,47 \%$ dos docentes analisados por meio do estudo dos seus currículos lattes, não têm formação específica em bioética, seja em nível de especialização, mestrado ou doutorado. A partir dos dados encontrados pelo autor, algumas considerações relativas ao perfil destes docentes devem ser ampliadas, como a formação e a experiência acadêmica que devem possuir, e quais os profissionais mais aptos a conduzir uma disciplina tão abrangente e complexa ${ }^{62}$.

É fato que poucos são os profissionais que detêm tamanha formação acadêmica para poder transitar por todos os temas que abrangem a bioética ${ }^{5}$. Alguns autores apregoam a necessidade dos docentes que lecionam a disciplina terem um sólido embasamento teórico, filosófico, ético e bioético, além dos conhecimentos inerentes à própria área de atuação ${ }^{7,12}$.

Segundo Guerra ${ }^{63}$, o campo de inserção da bioética é o das disciplinas ético-práticas e não o das disciplinas teórico-científicas. Ainda que não seja uma disciplina estritamente científica, a bioética não prescinde das interações com a ciência "como, por exemplo, no caso da clonagem terapêutica, no qual o bioeticista necessita de conhecimentos de biologia e de genética"63 (p. 162). 
Por outro lado, pode-se afirmar que é praticamente impossível alguém deter os conhecimentos de cada especialidade para o ensinamento da bioética, haja vista a complexidade de informações envolvidas que o docente teria que dominar nas diversas especialidades ${ }^{5}$.

Infere-se assim, a necessidade de uma postura ativa e inovadora do professor que ministra a disciplina ${ }^{7}$ de modo a estimular atitudes críticoreflexivas dos estudantes em consonância com o perfil profissional condizente com as expectativas atualmente requeridas pela sociedade.

Tendo em vista a complexidade que envolve a formação de docentes em bioética, espera-se dos que se dedicam ao ensino da disciplina condutas e práticas que possam servir de exemplos a serem seguidas pelos alunos, com 0 intuito de promover o desenvolvimento de uma competência política, social e, essencialmente, ética ${ }^{12}$.

As condutas dos docentes são de fundamental importância para a aprendizagem da ética ${ }^{62}$. Segundo Monteiro ${ }^{16}$, ao entrevistar docentes dos cursos de enfermagem, medicina e odontologia na cidade de Manaus - AM, os atributos mais citados para um bom professor de ética foram a vivência e a experiência profissional, características adquiridas ao longo da trajetória acadêmica.

De acordo com diferentes autores, os professores são considerados como referência pelos alunos, tanto nos aspectos técnicos quanto no relacionamento com os pacientes ${ }^{9,18,62}$. Dessa maneira, a formação ética dos futuros profissionais de saúde exige grande responsabilidade docente; ao passo que condutas inadequadas contribuem para uma formação descomprometida com princípios éticos ${ }^{35}$.

Matos e Tenório ${ }^{1}$ ao analisarem a percepção de alunos, professores e usuários acerca da dimensão ética na formação de graduandos de odontologia afirmam que a maioria dos alunos reconhece o estímulo à ética durante o curso, entretanto identificam professores que aparentam não se importar com essas questões e denunciam a falta de ética de alguns deles.

Recente estudo desenvolvido por Vieira e Neves ${ }^{64}$ com 506 estudantes de medicina demonstrou que " $66 \%$ dos alunos afirmaram ter observado conduta médica inadequada por parte de seus professores" ( $p 21$ ). 
Ao observar a atuação do professor, o aluno tende a assimilar a sua conduta $^{9,18}$. Portanto, é dever do docente incentivar a reflexão ética sobre a prática clínica vivenciada no dia a dia e subsidiar as informações necessárias para amparar tal reflexão ${ }^{65}$, contribuindo positiva e intencionalmente na formação ética dos estudantes ${ }^{9,18}$.

Não se deve, contudo, atribuir a responsabilidade pelo ensino da bioética somente aos professores da disciplina, mas que seja compartilhada por todo o corpo docente da instituição. O resgate da reflexão ética deve ser exercido por todos que se dedicam ao ofício de ensinar e exercitado como um hábito, o qual se tornará mais fácil quanto mais for praticado ${ }^{66}$.

Outro aspecto também bastante significativo no ensino da bioética diz respeito às melhores formas de desenvolver seus conteúdos. Promover discussões se reveste de importância haja vista a peculiaridade da disciplina trabalhar "mais com argumentos e menos com verdades"35 (p. 441), tornandose difícil avaliar qual o melhor método de ensino "devido à complexidade de medir posturas e comportamentos que, muitas vezes, envolvem valores e

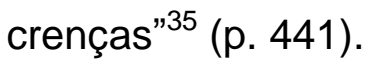

Diversos são os métodos para o ensino da bioética utilizados pelos professores para trabalhar com os alunos os conteúdos programáticos. Podem ser citados as aulas teóricas (magistrais), os seminários e estudos de casos com problemas bioéticos, com apresentação em grupo e posterior discussão, debates de textos, filmes ${ }^{33}$, além de simpósios via internet e conferências simultâneas ${ }^{5}$.

Merecem destaque a discussão de casos, o júri simulado, o role playing, a discussão de dilemas morais, os debates mediados pela arte, a apresentação de narrativas visuais e a discussão de filmes de cinema ${ }^{67}$.

Meira e Cunha ${ }^{68}$ alertaram sobre a ausência de discussão prática nas escolas médicas e apontam para o predomínio das aulas teóricas no ensino da ética. Aulas expositivas conduzidas de modo vertical são exercícios passivos com o intuito de preencher carga horária ${ }^{13}$ e frequentemente guardam pouca ou nenhuma relação com os dilemas vivenciados pelos alunos na prática profissional cotidiana ${ }^{69}$. As aulas teóricas podem ser uma das responsáveis pelo desinteresse de alunos de medicina pela bioética contribuindo para uma relação profissional-paciente menos humanizada ${ }^{34}$. 
O uso do cinema, como estratégia metodológica para abordagem bioética, é apresentado como uma alternativa eficaz e capaz de atingir os objetivos educacionais humanísticos à formação dos futuros profissionais de saúde ${ }^{3,4}$.

O Ensino à Distância (EAD), como ferramenta de ampliação do estudo da disciplina, é justificado como forma de unir o ensino às novas tecnologias da educação capaz de despertar ou aumentar o interesse pelos conteúdos de bioética $^{70}$.

A utilização da metodologia de ensino baseada na solução de problemas é reconhecida por muitos bioeticistas como a mais apropriada à disciplina de bioética ${ }^{71}$. Essa forma de abordagem possibilita ao aluno estimular a capacidade de ampliar seus conhecimentos por meio de situações observadas na realidade através do processo de ação-reflexão-ação ${ }^{59}$.

A Aprendizagem Baseada em Problemas é referenciada como alternativa viável para propiciar o desenvolvimento moral dos profissionais de saúde e capaz de promover a interação de saberes e o estímulo ao pensamento crítico e reflexivo ${ }^{72}$. As primeiras experiências com este método, no Brasil, ocorreram na Faculdade de Medicina de Marília, em 1997, e no curso de Medicina da Universidade Estadual de Londrina, em $1998^{13,73}$.

Paralelamente às questões metodológicas, depara-se também com a questão da carga horária recomendada para o desenvolvimento da temática bioética. O número de horas ideal é dependente e está intimamente relacionado com a quantidade de tempo requerida para desenvolver adequadamente 0 conteúdo ${ }^{74}$. Uma carga horária insuficiente não permite trabalhar os conteúdos de maneira adequada que possibilitem aos alunos 0 amadurecimento de posturas éticas necessárias diante dos conflitos e dilemas que encontrarão na vida profissional ${ }^{75}$.

Estudo realizado por Zanatta e Boemer ${ }^{33}$ identificou que de sete cursos de enfermagem desenvolvidos em quatro instituições diferentes no estado de São Paulo, apenas um curso possuía uma carga horária de 30 horas exclusiva para a disciplina bioética. Nos demais cursos eram reservados de 4 a 8 horas para os conteúdos de bioética de uma carga horária total de 30 a 76 horas de disciplinas como Ética Profissional, Metodologia de Pesquisa, Ética e 
Legislação em Enfermagem. Para Germano ${ }^{76}$ é dispensado à bioética a menor carga horária no âmbito dos cursos de enfermagem.

Siqueira ${ }^{13}$ alerta para a pouca valorização da disciplina bioética nos cursos de medicina, ao denunciar que, de um total de 8.640 horas da graduação, são reservadas apenas 50 horas para a referida disciplina, ou seja, $0,6 \%$ da carga horária integral.

Um estudo mais recente indica que no Brasil as faculdades de medicina destinam não mais que 45 horas para o ensino da bioética ${ }^{77}$. Na pósgraduação a situação não é diferente.

Os achados de Figueiredo ${ }^{52}$ constataram que o ensino da bioética na pós-graduação stricto sensu na área das ciências da saúde varia entre 10 e 50 horas, sendo que a maior carga horária é de 25 horas em 79 disciplinas analisadas.

Resultados semelhantes foram encontrados por Aires e cols. ${ }^{14}$ ao relatarem que o número médio de horas destinadas ao ensino da bioética em programas de pós-graduação em odontologia no Brasil é de 36 horas-aula. De acordo com $\mathrm{Kottow}^{78}$, não existe uma extensão ótima pré-estabelecida e consensual. A bioética geralmente ocupa os espaços que consegue conquistar na estrutura curricular.

Em virtude dos fatos anteriormente mencionados, para que a construção de conhecimentos e habilidades seja capaz de influenciar atitudes orienta-se que o ensino da bioética ocorra em pequenos grupos, com um estilo mais prático que teórico, que valorize a interação e a participação, com a utilização do debate como método de ensino-aprendizagem ${ }^{9,73}$.

A problematização em pequenos grupos tem sido defendida como a mais apropriada para o ensino da bioética ${ }^{9,10,33}$, estimulando, de forma aberta e democrática, a análise de ideias e crenças ${ }^{10}$, ainda que divergentes. A análise de casos reais com desvios éticos como recurso metodológico possibilita o desenvolvimento da habilidade discursiva e amplia a capacidade argumentativa ${ }^{78}$ com o intuito de gerar alternativas de solução de problemas morais que sejam eticamente aceitáveis ${ }^{10}$.

A combinação de aulas teóricas com atividades práticas - seminários discutidos em pequenos grupos parece ser a estratégia preferida pelos 
estudantes e a mais frequentemente adotada pelos docentes ${ }^{78}$, favorecendo um encontro reflexivo entre os atores envolvidos - professor e aluno ${ }^{9}$.

Dessa forma, a bioética, como parte da formação profissional, deve ser um tema trabalhado ao longo de todo o curso e esforços devem ser envidados para a sensibilização e capacitação docente por parte das instituições de ensino ${ }^{79}$.

\section{4. $O$ ensino da bioética no contexto da pós-graduação lato sensu: o panorama brasileiro}

A partir dos dados apresentados no tópico anterior, a estrutura e organização do ensino da bioética devem ser preferencialmente elaboradas de acordo com os conteúdos temáticos definidos segundo o contexto sóciocultural da localidade onde esteja instalado o curso, amparados por marcos conceituais e valendo-se de um conjunto harmônico e científico de metodologias.

Exemplificando, enquanto "em países do primeiro mundo, o ensino da bioética está voltado, principalmente, para os problemas éticos gerados pela aplicação de novas biotecnologias, no Brasil, os problemas bioéticos têm maior amplitude"56 (p.128-129). Aqui o enfoque deve estar direcionado especialmente às diversidades das questões sociais, econômicas, ambientais e de saúde pública.

Merece destaque duas perspectivas de análise da bioética desenvolvidas em diferentes culturas. A perspectiva anglo-americana, hegemonicamente principialista, que tem como característica principal a supervalorização do princípio da autonomia, acentuadamente individualista e voltada preferencialmente aos microproblemas ${ }^{56}$. E a perspectiva européia, que tem como linha de atuação o enfoque personalista cuja preocupação recai sobre a dimensão social do homem, com atenção aos interesses morais coletivos (macroproblemas) e com forte predomínio do princípio da justiça ${ }^{1,56}$.

Quanto à definição dos objetivos do ensino da bioética na pósgraduação, o primeiro obstáculo seria como transmitir conhecimento a partir de uma visão interdisciplinar, modificar atitudes e formar "novos" valores ${ }^{80}$. Em 
uma disciplina tão ampla e complexa, outro obstáculo seria determinar quais os temas que deveriam compor o conteúdo programático.

Nesse sentido, torna-se um desafio elaborar uma ementa de ensino para a bioética que contemple a multiplicidade de disciplinas envolvidas, haja vista a crescente incorporação de novidades tecnológicas com implicações morais diariamente na vida das pessoas ${ }^{5}$.

A estrutura de um curso de pós-graduação aborda temas a serem trabalhados em qualquer lugar do país que o profissional deseje estudar. Todavia, não somente os cursos de pós-graduação em bioética possuem peculiaridades que dificultam uma estruturação comum a ser adotada em todo território nacional.

Caramico e cols. ${ }^{5}$ sugerem que tópicos comuns sejam mantidos como, por exemplo, a história da bioética, os princípios e casos paradigmáticos e as declarações e códigos que surgiram após a crescente reflexão bioética no mundo. Rego ${ }^{65}$ sugere a inserção de conteúdos desde a filosofia da moral e da ciência - como fundamento para a reflexão moral autônoma - até as situações práticas e concretas que os profissionais vivenciam durante a prática cotidiana.

Diferentemente de uma pós-graduação, na graduação os estudantes ainda não se dão conta da real importância e consequência de uma formação ética adequada. $O$ entusiasmo com as possibilidades tecnológicas proporcionadas pelas disciplinas clínicas relega a um segundo plano a dimensão ética da atuação profissional. Os alunos da graduação reconhecem a necessidade, acham interessantes e até valorizam os aspectos éticos de sua formação, mas na prática acabam mudando o discurso, talvez pelas demandas e competitividade no mercado de trabalho.

Para Matos e Tenório" "a dimensão ética, evidenciada durante a graduação, parece ficar comprometida quando as determinações econômicas passam a fazer parte da complexidade que envolve a atenção profissional" (p.3262). Não se trata de responsabilizar exclusivamente a universidade pelas carências dos estudantes na graduação ${ }^{9}$. É importante compreender que o papel da escola na formação ética dos profissionais é limitado, porque esses valores também nascem da experiência pessoal de cada um, como, por exemplo, no âmbito familiar ${ }^{1}$. Todavia, a escola tem como função intervir para a construção de uma consciência ética que transforme o educando em cidadão ${ }^{6}$. 
Como alternativa para preencher esta carência ética existem os cursos de pós-graduação lato sensu - as especializações - em bioética. Estes cursos servem para resgatar e aprofundar temas e conceitos antes pouco trabalhados na graduação seja devido à metodologia de ensino utilizada ou à pequena carga horária dispensada à disciplina, contribuindo com o desenvolvimento moral dos participantes.

A tarefa principal da pós-graduação stricto sensu é produzir profissionais aptos para atuar em diferentes setores da sociedade, uma vez que é nesse nível de formação que ocorre a atividade de pesquisa científica e capacitação profissional ${ }^{81}$. Partindo desse entendimento, alguns estudiosos da bioética apregoam que uma das grandes missões da pós-graduação seria capacitar pesquisadores, docentes e profissionais de distintas áreas para realizar a análise ética no cotidiano da vida prática ${ }^{52}$.

Para Barchifontaine 82 "os cursos de pós-graduação têm por objetivo fomentar o desenvolvimento e o aperfeiçoamento profissional, constituindo-se como um momento essencial de formação, em todas as áreas profissionais" ( $p$. 399). Gradativamente, a procura e o interesse por cursos desta natureza têm crescido $^{82}$ e isso pode ser atribuído ao amplo campo de inserção da bioética que inclui, além dos dilemas biomédicos, "a discussão dos temas de direitos humanos e cidadania, questões ambientais sobre desenvolvimento sustentável e preservação da biodiversidade, poluição ambiental e discriminação social”"10 (p. 511).

O primeiro registro da introdução da bioética na estrutura curricular de um curso no Brasil ocorreu em um programa de pós-graduação na área médica voltado para preparar e capacitar profissionais para resolver dilemas e/ou conflitos éticos ${ }^{52,83}$. As atividades de ensino tiveram início em 1990, quando foi realizado no Hospital de Clínicas de Porto Alegre (HCPA) um curso intensivo de bioética, em colaboração com a Fundação Fullbrigth, com a participação do professor Robert Veatch, do Kennedy Institute of Ethics dos Estados Unidos.

A partir de 1994 o curso de pós-graduação em medicina (clínica médica) da Universidade Federal do Rio Grande do Sul (UFRGS) incluiu a disciplina de Bioética I em sua base curricular.

Em agosto de 1998, o Núcleo de Estudos e Pesquisa em Bioética (NEPeB), localizado na Universidade de Brasília, inicia seu primeiro curso de 
especialização em bioética, o qual se mantém até o momento, já estando na sua $17^{\mathrm{a}}$ edição regular com o oferecimento de 30 vagas anuais ${ }^{84}$.

De acordo com os objetivos do presente trabalho, é indispensável registrar o surgimento posterior de iniciativas similares, com ofertas episódicas e sem uma periodicidade definida de cursos de especialização em bioética, em outras regiões do Brasil:

- Centro Universitário São Camilo, em São Paulo, no qual é realizado o curso de especialização em Bioética e Pastoral Familiar;

- Instituto Oscar Freire - Faculdade de Medicina da Universidade de São Paulo (USP);

- Núcleo de Estudos de Bioética da Pontifícia Universidade Católica, em Porto Alegre (PUC-RS);

- Instituto Fernandes Figueira (IFF), vinculado à Fundação Oswaldo Cruz (Fiocruz);

- Núcleo de Bioética da Universidade Estadual de Londrina (UEL);

- Núcleo de Estudos em Bioética (NEB) da Pontifícia Universidade Católica do Paraná (PUC-PR).

O rápido e extraordinário avanço tecnocientífico, observado nas últimas décadas, roubou do homem o tempo necessário para uma reflexão ética mais prudente sobre as consequências que suas ações podem provocar na sociedade e meio ambiente ${ }^{6,18}$. Como resposta para vencer o preconceito de que nas universidades só se deva discutir tecnociência ${ }^{1}$ estas iniciativas e instituições surgem como alternativas para definitivamente incorporar e efetivar o discurso bioético na prática profissional.

O embasamento ético atualmente tão exigido para uma boa prática clínico-assistencial estimula a busca por novas formas de abordagens da realidade como, por exemplo, as reflexões éticas ${ }^{6}$. Desse modo, a formação em bioética, por meio de cursos de especialização, deve ser entendida como parte de um processo de construção da atuação profissional, a partir do aprimoramento da dimensão ética, ou seja, do desenvolvimento moral e de compromissos com bases mais sólidas do que apenas o desejo e a intuição ${ }^{1}$. 


\section{OBJETIVOS}

\subsection{Objetivo geral}

- Analisar cursos de pós-graduação lato sensu em bioética existentes no Brasil.

\subsection{Objetivos específicos}

- Conhecer os objetivos e métodos utilizados no processo de ensinoaprendizagem;

- Analisar o conteúdo programático preferencialmente abordado a partir das ementas e planos de ensino;

- Identificar a formação acadêmica dos docentes encarregados das disciplinas nos diferentes cursos;

- Analisar a percepção de coordenadores quanto a esta modalidade de ensino da bioética;

- Propor critérios de certificação para cursos de pós-graduação lato sensu em bioética no país. 


\section{MÉTODO}

O presente trabalho consiste em um estudo descritivo-analítico de caráter exploratório, de natureza qualitativa, cujo universo a ser pesquisado são cursos de pós-graduação lato sensu em bioética existentes ou já oferecidos no Brasil.

É oportuno ressaltar sobre a escolha dos cursos selecionados. Optouse por analisar seis cursos oferecidos tanto por instituições públicas quanto por instituições privadas, e como recorte metodológico foram escolhidos três cursos de instituições de cunho religioso (Centro Universitário São Camilo, PUC-RS e PUC-PR, instituições privadas) e três cursos de instituições laicas (USP - Instituto Oscar Freire, Fiocruz - Instituto Fernandes Figueira e UEL, instituições públicas). A escolha destes cursos deveu-se por serem estas instituições as pioneiras no ensino da bioética no Brasil.

A pesquisa descritiva é aquela em que o pesquisador procura conhecer e interpretar a realidade, sem nela interferir ou modificá-la ${ }^{86}$. Já o método adotado pode ser compreendido como o caminho que deverá ser seguido e que assume especificidades segundo o tipo de estudo. Para Minayo, o método constitui-se no caminho e no instrumental próprios de abordagem da realidade $^{87}$.

O método qualitativo responde a questões muito particulares. Preocupa-se com um nível de realidade difícil de ser quantificada, pois trabalha com universos de significados que não podem ser reduzidos a operacionalizações de variáveis ${ }^{88}$, ou seja, produz conhecimento a partir da realidade das pessoas, não envolvendo instrumental estatístico como procedimento.

A abordagem qualitativa se afirma no campo da subjetividade e do simbolismo, ao aproximar sujeito e objeto por meio dos significados, motivos, aspirações, crenças e valores expressos pela linguagem comum no cotidiano ${ }^{87}$.

Para o alcance dos objetivos propostos, apresenta-se inicialmente 0 marco referencial deste estudo - o programa de pós-graduação lato sensu em bioética da UnB - e posteriormente detalha-se o procedimento metodológico do trabalho em dois momentos, assim divididos: 
1. Análise documental das ementas e planos de ensino dos cursos oferecidos pelas universidades e/ou instituições de ensino;

2. Entrevista semi-estruturada com os coordenadores de cada curso.

\subsection{Marco referencial do estudo - histórico, estrutura e conteúdo básico do programa de pós-graduação lato sensu em bioética da Universidade de Brasília}

Embora tardia, a bioética brasileira, já nos seus primórdios, na década de 1990, se direcionava na busca de uma reflexão autóctone, voltada à dimensão social e em consonância com os dilemas vivenciados no campo da saúde pública ${ }^{39}$. A publicação dos livros $A$ dimensão da ética em saúde pública de autoria de Volnei Garrafa, editado pela Faculdade de Saúde Pública da Universidade de São Paulo e Kellogg Foundation em 1995 e A terceira margem da saúde de Fermin Roland Schramm editado pela Universidade de Brasília em 1996, podem ser considerados os marcos iniciais da reflexão bioética brasileira na dimensão acadêmica ${ }^{84}$.

De acordo com Gomes e cols. ${ }^{84} 0$ desenvolvimento mais orgânico do ensino e da pesquisa em bioética também tiveram início nesse período, mais precisamente em 1994, com a criação e coordenação do professor Volnei Garrafa do Núcleo de Estudos e Pesquisa em Bioética (NEPeB), vinculado ao Centro de Estudos Avançados Multidisciplinares (CEAM) e ao Departamento de Saúde Coletiva (DSC) da Faculdade de Ciências da Saúde, ambos na Universidade de Brasília. Nos três primeiros anos da fase de implantação, o $\mathrm{NEPeB}$ atuou como instância de divulgação da bioética no âmbito universitário institucional ${ }^{84}$.

O NEPeB iniciou suas atividades no campo do ensino de graduação regular propriamente dito, em 1994, com o oferecimento da disciplina "Introdução à Bioética" (dois créditos - 30 horas/aula-semestre) para todas as carreiras acadêmicas da UnB e da disciplina "Bioética" (quatro créditos), obrigatória para o curso de odontologia. Logo depois, em 1995, com a criação do programa de pós-graduação stricto sensu em ciências da saúde, o Núcleo começou a oferecer regularmente a disciplina de "Bioética" em nível de mestrado e doutorado (quatro créditos). Concomitantemente, o NEPeB 
começou desenvolver pesquisas científicas direcionadas à área de bioética com expressivo número de publicações na época.

A partir das exitosas experiências acima, em agosto de 1998, o NEPeB dá início à primeira turma do curso de pós-graduação lato sensu em bioética, com duração experimental de um ano e meio na sua primeira edição (agosto de 1998 - dezembro de 1999 - 460 horas/aula). Atualmente o curso está em sua $17^{a}$ edição anual e regular, desenvolvido de março a dezembro de cada ano e com um total de 375 horas/aula. Vale ressaltar transformações ocorridas no Núcleo durante esse período, tanto nas características institucionais quanto naquelas relacionadas à própria formulação do conhecimento científico no campo da bioética, com reflexos significativos na produção acadêmica de monografias, dissertações e teses.

No nível institucional, destaca-se o reconhecimento da Organização das Nações Unidas para a Educação, a Ciência e a Cultura (Unesco) para com as atividades desenvolvidas pelo $\mathrm{NEPeB}$, conferindo-lhe o título de Cátedra Unesco de Bioética da Universidade de Brasília em 2004 e, mais recentemente em 2008, a criação do programa de pós-graduação stricto sensu (mestrado e doutorado) em bioética, pioneiro na oferta de doutorado neste nível, em uma universidade pública ${ }^{84}$. A criação deste programa é fruto da experiência acumulada e do saber consolidado pela Cátedra, tanto em gestão como em pesquisa no nível da pós-graduação, adquirido durante os anos com a oferta do curso de especialização.

No nível acadêmico, é por meio da Cátedra que foi apresentada à comunidade acadêmica a Bioética de Intervenção, durante o Sexto Congresso Mundial de Bioética, em 2002, que recupera o ponto de partida da disciplina: ampliar o âmbito de atuação da bioética para a dimensão social; ratificar a transdisciplinaridade como estratégia de abordagem bioética; e incorporar os direitos humanos como eixo orientador da ética na prática coletiva ${ }^{57,84,85}$.

Essas transformações remontam ao passado do NEPeB com um histórico de politização da bioética para o social e o coletivo em oposição à discussão restrita ao campo biomédico e individual.

Imediatamente após sua criação, o NEPeB foi o primeiro núcleo de bioética no Brasil reconhecido formalmente como "Grupo Consolidado de Pesquisa" junto ao Conselho Nacional de Desenvolvimento Científico e 
Tecnológico (CNPq). A estreita ligação com o Núcleo de Estudos em Saúde Pública (NESP), também vinculado ao CEAM e ao DSC, permitiu relacionar o campo multi-inter-transdisciplinar da bioética à área da saúde pública.

Esse aspecto é importante considerar, pois estas instâncias - o DSC, NESP e NEPeB - congregam docentes e pesquisadores com participação e envolvimento acadêmico no Movimento da Reforma Sanitária brasileira e na construção do Sistema Único de Saúde, bem como disposição para atuar na área dos direitos humanos.

O referido Núcleo (NEPeB) possui uma trajetória de luta por uma bioética crítica, que leva em conta o contexto no qual estão inseridos os principais problemas que afligem tanto o Brasil como a região latinoamericana, ou seja, a exclusão social, as diferentes formas de discriminação, a escassez de recursos públicos.

Uma bioética que prioriza o coletivo, o "nós" em detrimento do "eu", individualista, tão prevalente no supervalorizado princípio da autonomia. Uma bioética que contempla na discussão valores como a solidariedade, a cooperação, o respeito à diversidade cultural e ao pluralismo moral, os direitos humanos, a responsabilidade social e a equidade, características mais próximas do nosso dia a dia, ainda incipientes e pouco trabalhados pela bioética brasileira naquela época no meio acadêmico.

Esta identidade vem sendo construída e sendo fortalecida como decorrência natural dos mais de vinte anos de atividades desenvolvidas pelo Núcleo como, por exemplo, nas assessorias e apoio acadêmico-científico a órgãos públicos e entidades profissionais; na participação e organização de eventos e nas relações de intercâmbio com organismos internacionais.

A aprovação e homologação como Cátedra Unesco de Bioética, a partir de 2005, permitiu ampliar e consolidar a bioética ao campo da saúde pública como realidade palpável. Merece destaque a participação da Cátedra na construção da proposta brasileira para a elaboração da DUBDH na defesa da inclusão de temas sociais, sanitários e ambientais e também a assinatura, logo a seguir, de um acordo de cooperação entre UnB e Unesco no sentido de desenvolvimento do Core Curriculum (CC) de bioética proposto por aquele organismo internacional no campo da bioética, fundamentado na Declaração Universal sobre Bioética e Direitos Humanos. 
Todo este processo de intensa atividade acadêmica refletiu no modo de estruturar e formatar o curso de especialização da UnB, conferindo-Ihe uma identidade própria ao longo dos anos.

Ininterruptamente, desde sua criação, o curso de especialização em bioética da UnB preservou seu espírito laico, democrático, transdisciplinar e de respeito ao pluralismo moral, características fundamentadas pelo estatuto epistemológico da bioética.

A metodologia a ser desenvolvida na presente tese de doutoramento prevê um estudo descritivo e analítico de diferentes cursos de especialização em bioética oferecidos no Brasil, comparativamente ao programa desenvolvido pela Cátedra Unesco de Bioética da UnB.

Não é este o espaço, contudo, de uma análise aprofundada do referido programa. Entretanto, para melhor compreensão do processo de apresentação do tema, é indispensável que pelo menos seja apresentado, nesta altura, a estrutura básica do referido curso, o que é feito a seguir.

A estrutura básica dos cursos oferecidos pela Cátedra da UnB tem como característica sua distribuição em módulos dispostos sequencialmente de modo a contemplar os principais temas e abordagens discutidas em bioética, tomando como eixo condutor, como já assinalado acima, a Declaração Universal sobre Bioética e Direitos Humanos da Unesco.

. Módulo I: Introdução à Bioética - 15 horas-aula (01 crédito) e têm como objetivos apresentar a bioética para os alunos, a estrutura do curso, a proposta epistemológica e as linhas teóricas a serem adotadas. As principais referências bibliográficas adotadas são as obras: Bases conceituais da bioética - enfoque latino-americano (Garrafa, Kottow e Saada - orgs.); Pesquisas em Bioética no Brasil de hoje (Garrafa e Cordón - orgs.); e Iniciação à Bioética (Costa, Garrafa e Oselka - orgs).

. Módulo II: Filosofia Básica - 30 horas-aula (02 créditos) cujo objetivo é apresentar os estudos filosóficos básicos sobre ética, moral, liberdade, autonomia e justiça, referências temáticas para a Bioética. A escolha dos autores obedece ao critério de sua pertinência aos estudos bioéticos, dando-se preferência àqueles pensadores que constituem o suporte epistemológico da 
disciplina como, entre outros, Hans Jonas, Immanuel Kant, John Stuart Mill, Mary Warnock, Enrique Dussel.

. Módulo III: Fundamentos da Bioética - 90 horas-aula (06 créditos) inicialmente o módulo propunha dois objetivos: apresentar, fundamentar e discutir as teorias predominantes nos estudos bioéticos; e desenvolver análises do processo de importação acrítica das teorias hegemônicas em bioética pelos países periféricos, além de apresentar contribuições teóricas importantes para a bioética desenvolvida pelas Ciências Humanas. Têm como referência as obras Principles of Biomedical Ethics (Beauchamp e Childress), A Critique of Principlism (Clouser e Gert) e Fundamentos da Bioética (Engelhardt).

Atualmente, após a assinatura do convênio para a implementação do Core Curriculum, foi incorporada a DUBDH como referencial teórico, além do estudo de autores como Peter Singer, Hans Jonas, Paulo Freire e de teorias morais latino-americanas como, por exemplo, a Colonialidade e a Bioética de Intervenção.

. Módulo IV: Metodologia de Pesquisa - 45 horas-aula (03 créditos). Este módulo visa fornecer as noções fundamentais sobre o pensamento e a abordagem científica de um problema, o levantamento de questões de pesquisa, as características da redação científica e os métodos das Ciências Humanas e da Filosofia utilizados pela Bioética. Fornece, assim, a base sobre a qual os estudantes começarão a desenvolver o plano de redação do Trabalho de Conclusão de Curso (TCC) e o desenvolvimento de um projeto de pesquisa a ser defendido no final do curso. Textos e projetos de pesquisa defendidos nos cursos de mestrado e doutorado da Faculdade de Ciências da Saúde e de outros programas de pós-graduação da UnB são utilizados e comentados, assim como livros de fundamentação da Metodologia Científica.

. Módulo V: Bioética Clínica e Ética em Pesquisa - 60 horas-aula (04 créditos). Objetiva apresentar a área de atuação da Bioética nos conflitos éticos gerados em torno das práticas de assistência à saúde e à pesquisa com seres humanos. Em Bioética Clínica são abordados temas referentes à prática clínica no início, transcurso e fim de vida, bem como a contribuição teórica e prática da 
bioética no contexto da relação profissional-paciente. Casos típicos como recusa do paciente a tratamentos estabelecidos e incompatibilidade cultural com propostas terapêuticas e os Comitês Hospitalares de Bioética também são abordados e discutidos.

Com relação à ética nas pesquisas, o módulo pretende capacitar profissionais para a atuação em comitês de ética em pesquisa e/ou a planejar eticamente projetos de investigação. São apresentadas e analisadas as diretrizes e normas, nacionais e internacionais, regulamentadoras da pesquisa envolvendo seres humanos. É discutida a eticidade da utilização de animais não humanos em pesquisas e a estrutura e operacionalização do Sistema CEP/CONEP. São organizadas, ainda, discussões em grupo, como se fossem participantes de um CEP, analisando protocolos de pesquisa especialmente construídos para esta finalidade.

. Módulo VI: Bioética das Situações Emergentes - 75 horas-aula (05 créditos). Análise das situações provocadas pelas descobertas, pelos usos e pelos desdobramentos sociais da biotecnociência, da doação e do transplante de órgãos e tecidos humanos, das novas tecnologias reprodutivas, da utilização terapêutica de células tronco-embrionárias e genômicas, dilemas surgidos a partir do acelerado desenvolvimento biotecnicocientífico pós Segunda Guerra Mundial. As principais referências são as obras $O$ Mercado Humano: estudo bioético da compra e venda de partes do corpo (Berlinguer e Garrafa) e A Bioética no século XXI (Garrafa e Costa - orgs).

. Módulo VII: Bioética das Situações Persistentes -60 horas-aula (04 créditos). Traz para análise temas-chave da bioética, dilemas que se repetem cotidianamente na história da saúde e da doença dos seres humanos, que apesar de anteriores ao desenvolvimento biotecnicocientífico ocorrido a partir da segunda metade do século XX, foram atingidas pelo mesmo e, por isso, tornaram-se objetos de estudo dos bioeticistas a partir de outros referenciais analíticos. Podem ser citados dilemas como aborto, eutanásia, alocação e distribuição de recursos escassos, saúde pública, diferentes formas de discriminação, estigmatização e exclusão social. Dentre as referências 
utilizadas podem ser citadas as obras Ética da Saúde (Berlinguer) e Bioética, Poder e Injustiça (Garrafa e Pessini - orgs).

- Módulo VIII: Trabalho de Conclusão do Curso. Tem como objetivo orientar os estudantes na realização de um trabalho que possa servir futuramente para a publicação em forma de artigo. Deve ser desenvolvido de forma individual e ter como tema um dos tópicos expostos nos módulos III, V, VI ou VII.

Nesse sentido, o curso de especialização da UnB tem possibilitado aos profissionais de diferentes áreas uma formação cujo objetivo é proporcionar uma ampliação conceitual dos referenciais da bioética, aprofundando e reconstruindo conhecimentos a partir da realidade dos macroproblemas sociais, sanitários e ambientais - encontrados no Brasil e na América Latina.

\subsection{Do procedimento metodológico}

\subsubsection{Primeiro momento - da análise documental}

Nesta etapa os documentos analisados foram as diretrizes e as estruturas curriculares adotadas nos cursos de especialização em bioética. Foi realizado contato por telefone e correio eletrônico com o coordenador de cada curso expondo os motivos da pesquisa e solicitando o envio da documentação.

As informações contidas nos documentos foram submetidas a uma leitura flutuante para, a seguir, atingir níveis mais aprofundados, de modo que se pudesse garantir a identificação de dados significativos relacionados ao alcance dos objetivos propostos. A partir do acesso às diretrizes e das estruturas curriculares bem como da filtragem dos temas relacionados às disciplinas que integram os cursos, as informações receberam tratamento descritivo e analítico.

Para o tratamento dos dados levantados, estas informações foram dispostas em um quadro-síntese para análise das características de cada curso correspondente às instituições de ensino pesquisadas. Os quadros-síntese de cada curso tiveram por objetivo facilitar o manuseio de grande número de 
informações, como histórico do curso, período em que é ou foi realizado o curso, as ementas e planos de ensino das disciplinas ministradas, carga horária, método utilizado no processo ensino-aprendizagem, bibliografia utilizada, corrente teórica em bioética adotada e formação acadêmica do corpo docente.

Esta análise teve como finalidade realizar um comparativo dos cursos selecionados com o curso oferecido regularmente pela Cátedra Unesco de Bioética da Universidade de Brasília desde 1998. Com relação ao levantamento e disposição das áreas de estudo trabalhadas e desenvolvidas em cada curso será tomado como referência o modelo simplificado adotado no programa stricto sensu (mestrado e doutorado) em bioética da UnB - três linhas de pesquisa e dez unidades temáticas no total - descritos a seguir:

a) Fundamentos de Bioética: tem como propósito estudar os referenciais, fundamentos e princípios de sustentação epistemológica da bioética;

1 - Bases Epistemológicas da Bioética: estudo das bases conceituais de sustentação teórica da bioética incluindo elementos de filosofia moral aplicada, as tendências ou correntes tradicionais da disciplina, além das novas tendências em construção;

2 - Bioética e Direitos Humanos: investigação e interconexão entre bioética e direitos humanos, identificando os pontos de aproximação e distanciamento entre os dois campos do saber;

3 - Bioética e Pluralismo: tem como objetivo mapear e examinar outras éticas da vida e a diversidade nas concepções de humanidade, corpo humano, natureza, vida, morte, bem-estar e saberes tradicionais de distintos povos do Brasil e do Mundo;

4 - Ética Aplicada e Bioética: fundamentação conceitual, reflexão e problematização de valores morais aplicados a práticas sociais específicas, tais como: informação e comunicação, educação e atividades profissionais diversas, com ênfase na tomada de decisão ética e resolução de conflitos;

b) Situações Emergentes em Bioética: aborda questões, situações, conflitos ou problemas éticos provocados pelos avanços 
biotecnicocientíficos sobre a saúde humana em seu conceito amplo, bem-estar animal e integridade do ambiente e seus diversos ecossistemas;

1 - Bioética Ambiental e Proteção Animal: trata de questões em torno da degradação ambiental, destruição de formas tradicionais de vida, conservação do patrimônio genético, proteção de gerações futuras e crueldade com animais relacionados com a atividade industrial, agropecuária, geração de energia e exploração de riquezas;

2 - Ética e Biotecnociência: relaciona-se aos conflitos éticos envolvidos com o desenvolvimento, produção e uso de novas biotecnologias, seus impactos sociais e mecanismos de regulação e controle social;

3 - Ética em pesquisas com seres humanos: sistemas nacionais e internacionais de revisão ética da pesquisa, problemas éticos em torno de procedimentos metodológicos das ciências da saúde e das humanidades, conflitos de interesse envolvendo o complexo industrial da saúde e as práticas de experimentação;

c) Situações Persistentes em Bioética: trata de questões, situações, conflitos ou problemas éticos relacionados a problemas historicamente persistentes no campo da saúde e aquelas provocadas por situações de injustiça e exclusão social;

1 - Bioética Clínica: estudo das situações clínicas e relações de assistência à saúde relacionadas com o início, transcurso e fim da vida humana;

2 - Bioética e Atenção em Saúde: estudo ético dos fundamentos que sustentam o Sistema Único de Saúde e outros sistemas nacionais de saúde, partindo da universalidade do acesso e envolvendo as diversas práticas da saúde coletiva;

3 - Bioética Social: estudo das diferentes situações de exclusão e discriminação relacionadas com os referenciais incluídos na Declaração Universal sobre Bioética e Direitos Humanos da Unesco.

Foi incluída para compor o corpo de textos a Resolução do Conselho Nacional de Educação elaborada pela Câmara de Educação Superior (CNE/CES) nº 01 de 08 de junho de 2007 (Anexo 1) que estabelece as normas 
para o funcionamento de cursos de pós-graduação lato sensu, em nível de especialização ${ }^{19}$.

\subsubsection{Segundo momento - das entrevistas semi-estruturadas}

O instrumento utilizado para o levantamento destes dados foi um roteiro de entrevista semi-estruturada realizada com os coordenadores, responsáveis pela condução dos cursos de pós-graduação. É importante ressaltar que para o curso de especialização da UnB foi selecionado um professor que já foi coordenador em edições passadas e que atua junto ao curso desde a primeira edição, também docente e orientador no programa de pós-graduação em bioética stricto sensu na mesma universidade.

Foi enviado por correio eletrônico junto com o instrumento para a coleta dos dados (Anexo 2), o Termo de Consentimento Livre e Esclarecido - TCLE (Anexo 3) e o parecer de aprovação do Comitê de Ética em Pesquisa (Anexo 4), garantindo o sigilo da identidade dos participantes e a confidencialidade das informações prestadas, como preconizado pelas exigências éticas. O período de obtenção dos dados foi de agosto a dezembro de 2014.

A escolha dos participantes da pesquisa deveu-se ao fato de estarem estes envolvidos no processo de estruturação geral do curso e da coordenação e por entendermos compreenderem a bioética em suas diferentes modalidades de ensino.

A entrevista semi-estruturada é considerada como um dos instrumentos mais utilizados na pesquisa qualitativa pela possibilidade de acesso às informações desejadas. De acordo com Pope e Mays ${ }^{89}$, são conduzidas com base em uma estrutura flexível, consistindo em questões abertas que definem a área a ser explorada, a partir da qual o entrevistador e a pessoa entrevistada podem divergir a fim de prosseguir com uma ideia ou resposta em maiores detalhes.

Nesses casos, segundo Minayo ${ }^{87}$ :

A unidade de significação não é composta pela soma das respostas de cada indivíduo para formar uma relevância estatística. E, sim, ela se constrói por significados que conformam uma lógica própria do grupo ou, mesmo, suas múltiplas lógicas (com grifos no original, p.192). 
O instrumento para a coleta dos dados foi elaborado contendo duas partes (Anexo 2). Na primeira, buscou-se traçar o perfil dos entrevistados por meio dos seguintes aspectos: gênero, idade, formação profissional, formação acadêmica e atuação em bioética.

A segunda parte, o roteiro para entrevista, consistiu de 10 perguntas para livre manifestação do entrevistado de forma a contemplar os seguintes temas:

- os conteúdos programáticos de cada curso (referenciais teóricos, objetivos, estrutura curricular, métodos de ensino-aprendizagem, qualificação do corpo docente) - perguntas 1 a 5 e;

- os requisitos indispensáveis para a formação em bioética (perfil dos alunos, aproximação entre teoria e prática, necessidade e importância da bioética para a atuação profissional, conhecimento necessário, critérios de acreditação dos cursos) - perguntas 6 a 10.

Pretendeu-se nesse momento apreender os significados identificados pelos atores envolvidos com o ensino da bioética no Brasil, levando em consideração sua trajetória na bioética e experiência acadêmica.

Nesse sentido, a pesquisa qualitativa é o instrumento mais apropriado para a análise dos fenômenos que se busca entender, pois está relacionada aos significados que as pessoas atribuem às suas experiências do mundo social e como compreendem essa vivência ${ }^{89}$.

Segundo Minayo ${ }^{87}$, para o tratamento dos dados qualitativos a Análise de Conteúdo é o procedimento metodológico mais comumente utilizado. Esse método é definido por Bardin ${ }^{90}$ como:

$$
\begin{aligned}
& \text {... um conjunto de técnicas de análise das comunicações } \\
& \text { visando obter, por procedimentos, sistemáticos e objetivos de } \\
& \text { descrição do conteúdo das mensagens, indicadores } \\
& \text { (quantitativos ou não) que permitam inferência de } \\
& \text { conhecimentos relativos às condições de produção/recepção } \\
& \text { (variáveis inferidas) dessas mensagens }{ }^{90} \text { (p. 42). }
\end{aligned}
$$

Este conjunto de técnicas é utilizado com maior freqüência para estudar dados de natureza qualitativa quando não se podem aplicar técnicas estatísticas. Tem o intuito de analisar os principais conceitos ou temas abordados em um determinado texto. 
Para $\operatorname{Bardin}^{90}$, a análise de conteúdo tem por finalidade identificar indicadores que possibilitem obter conhecimentos relacionados com a produção dessas mensagens, ou seja, a transmissão de um significado de um emissor a um receptor. Busca-se, dessa maneira, conhecer os significados subjacentes, um outro lado da realidade. Segundo a autora:

A análise de conteúdo é utilizada como um instrumento de diagnóstico, de modo que se possam levar a cabo inferências específicas ou interpretações causais sobre um dado aspecto da orientação comportamental do locutor ${ }^{90}$ (p.140).

A análise de conteúdo compreende três fases que se complementam cronologicamente: a pré-análise; a exploração do material; e o tratamento dos resultados, a inferência e a interpretação.

A pré-análise se caracteriza por organizar, sistematizar e operacionalizar as ideias iniciais com o intuito de subsidiar as operações sucessivas em um plano de análise. Bardin ${ }^{90}$ ensina que esta fase compreende a escolha dos documentos a serem analisados, a formulação das hipóteses e objetivos e a escolha de índices e subsequente elaboração de indicadores que fundamentem a interpretação.

A fase seguinte consiste na exploração do material selecionado a partir de operações de codificação nas quais os dados são trabalhados sistematicamente em unidades que possibilitem descrever as características do conteúdo. As unidades destacadas podem ser: de registro - a palavra, o tema, o objeto, o personagem, o acontecimento, o documento; e de contexto definidas como segmentos da mensagem que permitem compreender os significados da unidade de registro.

A maior parte dos procedimentos são organizados por um processo de categorização (análise categorial ou das categorias) em razão da classificação de elementos (caracteres) comuns - as unidades de registro - constitutivos de um conjunto.

De acordo com Bardin ${ }^{90}$ :

A categorização tem como primeiro objetivo fornecer, por condensação, uma representação simplificada dos dados brutos... assenta implicitamente na crença de que a categorização (passagem de dados brutos a dados 
organizados) não introduz desvios (por excessos ou por recusa) no material, mas que dá a conhecer índices invisíveis, ao nível dos dados brutos" (p.119).

Para um resultado fidedigno a categorização preconizada por Bardin ${ }^{90}$ exige: exclusão mútua no qual cada elemento não seja classificado em duas categorias diferentes; homogeneidade em relação à identificação e forma de análise em todas as categorias; exaustão, ou seja, esgotar a totalidade do texto; objetividade e fidelidade dos codificadores na identificação dos temas e categorias pertinentes ao conteúdo e objetivo da pesquisa.

Foi estabelecido, para o presente estudo, como unidade de registro o tema (análise temática) que, segundo $\operatorname{Bardin}^{90}$, permite diferentes possibilidades de categorização (análise categorial), por ser considerada rápida e eficaz. Foram definidas duas categorias temáticas para a análise do objeto desta pesquisa, resultantes do agrupamento de categorias que emergiram dos dados apurados: o perfil acadêmico dos cursos e a formação profissional em bioética.

$\mathrm{Na}$ fase final da análise de conteúdo se procede ao tratamento dos resultados, ou seja, o processo de interpretação e inferência. É oportuno ressaltar que a análise de conteúdo possibilita análises quantitativas bem como qualitativas. No primeiro, quantifica-se a frequência de determinados elementos da mensagem por meio de métodos estatísticos de validação, sendo mais objetivo e fiel. No segundo, observa-se a presença ou ausência de determinado aspecto do conteúdo a partir da inferência levantada, o que corresponde a um procedimento mais intuitivo e mais aprofundado ${ }^{90}$.

Para a presente pesquisa foi empregada a análise categorial temática tanto para o corpo de dados (as diretrizes e as estruturas curriculares dos cursos selecionados) como para a interpretação das entrevistas realizadas com os coordenadores para a verificação dos objetivos propostos.

A escolha da abordagem qualitativa para o estudo proposto tendo como referencial metodológico a Análise de Conteúdo de Bardin para o tratamento analítico dos dados, deveu-se por esta permitir conhecer e interpretar o entendimento dos atores selecionados, considerando as características do contexto no qual estão inseridos - as universidades e/ou instituições de ensino. 


\subsection{Da avaliação prévia por um Comitê de Ética em Pesquisa}

Em cumprimento às exigências éticas da Resolução 466/2012 0 projeto de pesquisa foi apresentado e submetido à análise prévia pelo Comitê de Ética em Pesquisa da Faculdade de Ciências da Saúde da Universidade de Brasília (Anexo 4). Após parecer favorável por parte do CEP, a investigação foi iniciada. 


\section{RESULTADOS E DISCUSSÃO}

Os resultados serão apresentados de modo que seja possível compreender as principais particularidades dos cursos e também as percepções dos coordenadores no que se refere à formação em bioética nesta modalidade de ensino, ou seja, na pós-graduação lato sensu. A apresentação dos Resultados, conjuntamente à Discussão, será feita em dois momentos ou tópicos, a seguir.

\subsection{Primeiro momento - Análise documental dos cursos selecionados}

Por meio de contato telefônico e correio eletrônico, solicitou-se dos coordenadores responsáveis pelos cursos os documentos acima mencionados. No levantamento realizado, observou-se que a maioria dos cursos tem como origem instituições com núcleos constituídos e reconhecida tradição e expressividade acadêmica em bioética.

Passamos, a seguir, apresentar os dados analisados e a um resgaste histórico sobre os cursos de acordo com as particularidades de cada instituição.

\subsubsection{Curso de Especialização em Bioética e Pastoral da Saúde do Centro Universitário São Camilo em São Paulo}

A instituição possui como característica principal a abordagem das questões éticas da vida sob a perspectiva dos valores éticos cristãos. Tem como iniciativa a defesa e a valorização da humanização dos cuidados e serviços de saúde frente ao crescente uso da tecnologia e da despersonalização do cuidado, buscando soluções para os dilemas vivenciados pela bioética clínica ${ }^{45}$. A reflexão tem como base uma ética teológica aberta ao diálogo com a ciência, com teólogos, filósofos e profissionais de saúde.

É importante registrar que a instituição produziu em 1987 o primeiro texto didático de bioética tendo como público alvo os profissionais de saúde originalmente com o título de Bioética e Saúde. Sob a liderança dos 
Camilianos, Ordem Religiosa que tem como atuação o mundo da saúde, realizou-se em meados dos anos noventa uma série de quatro eventos com a temática da bioética e sua interface com a saúde na cidade de São Paulo, cujo resultado foi a publicação do livro Fundamentos de Bioética organizado por Leo Pessini e Christian de Paul de Barchifontaine ${ }^{46}$.

O curso de especialização em Bioética e Pastoral da Saúde teve início em 1999, sendo oferecido duas vezes ao ano, no início de cada semestre letivo. Tem dentre seus objetivos a reflexão sobre a bioética teológica a partir de valores da vida cristã, explorando possíveis caminhos de diálogo com a bioética secular, autônoma e racional, à luz das ciências humanas e da temática bíblica teológica como, por exemplo, curas, milagres, dor, sofrimento, morte. Visa também capacitar os agentes da pastoral da saúde para a implementação da pastoral de acordo com o referencial e as ações da Confederação Nacional dos Bispos do Brasil (CNBB).

O curso atualmente é oferecido regularmente, tendo já concluído 26 turmas. A instituição oferece cursos de educação continuada em bioética e possui um programa de pós-graduação stricto sensu de mestrado e doutorado em bioética. É responsável pela publicação da Revista Bioethikós periódico dedicado ao debate e a reflexão de forma transdisciplinar ${ }^{46}$.

A seguir serão mostrados, na tabela 1 , os dados relacionados com a estrutura curricular - as disciplinas ofertadas distribuídas por unidades temáticas e unidades de aprendizagem de acordo com as linhas de pesquisa. 
TABELA 1 - DISTRIBUIÇÃO DAS DISCIPLINAS DO CURSO OFERECIDO PELO CENTRO UNIVERSITÁRIO SÃO CAMILO POR UNIDADES DE APRENDIZAGEM E UNIDADES TEMÁTICAS DE ACORDO COM AS LINHAS DE PESQUISA

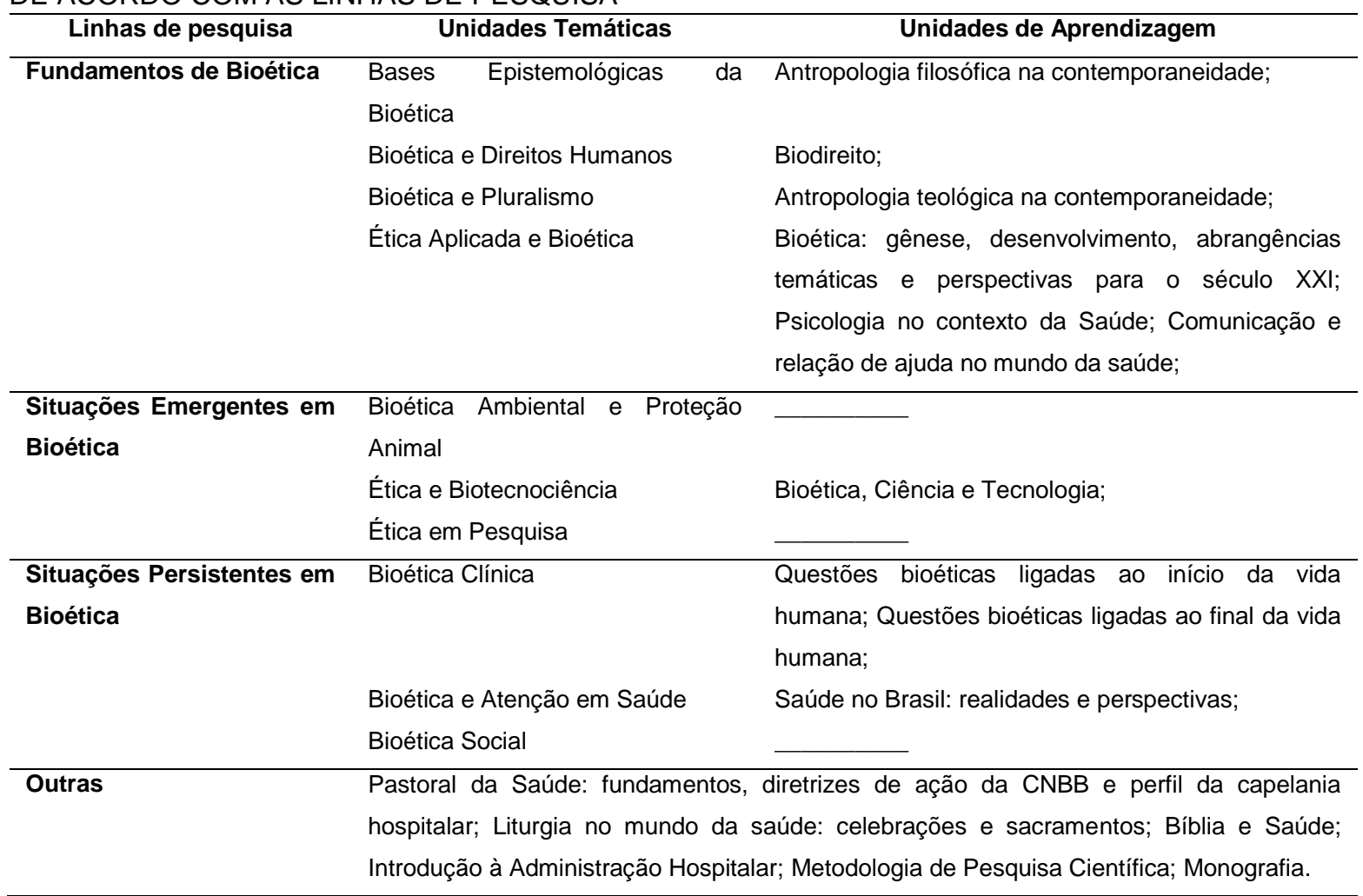

Fonte: pesquisa do autor, 2015.

\subsubsection{Curso de Especialização em Bioética da Pontifícia Universidade Católica do Paraná}

O curso de especialização em bioética da PUC-PR é oferecido e administrado pelo Núcleo de Estudos em Bioética (NEB) da referida universidade. $O$ curso conta com um grupo de professores que atuam nas seguintes áreas: Bioética, Biologia, Direito, Enfermagem, Ética, Filosofia, Fisioterapia, Fonoaudiologia, Medicina, Medicina Veterinária, Odontologia, Psicologia e Teologia.

Tem como característica essencial promover e estimular o debate de uma bioética pluralista, interdisciplinar e orgânica, voltada para a prática, desafiadora e crítica. Quatro turmas de especialistas já foram concluídas entre os anos de 2002 a 2010, tendo como público profissionais de diferentes áreas das ciências biológicas e da saúde, professores, pesquisadores e demais interessados nos temas de ética no campo da saúde e da tecnociência, sem 
restrições ou direcionamento para determinada área ou carreira. O conteúdo abordado no curso está distribuído em uma carga horária total de 360 horas.

É oportuno destacar que de acordo com os programas pedagógicos disponibilizados notou-se que houve mudanças no formato do curso através dos anos com a exclusão ou inclusão de módulos nem sempre ofertados regularmente.

O corpo docente, composto por dezessete professores predominantemente da área da saúde, está assim distribuído: doze do gênero masculino e cinco do gênero feminino, cuja titulação acadêmica está dividida em três especialistas, sete mestres e sete doutores. Identificou-se também a substituição de docentes entre os cursos realizados.

Em 2012 a universidade dá início ao programa de pós-graduação stricto sensu em bioética nível mestrado acadêmico na Escola de Saúde e Biociências com o objetivo de realizar estudos e pesquisas tendo como características a interdisciplinaridade, o respeito a diversidade moral, cultural e religiosa e a contextualização, a leitura crítica e integral da realidade sociocultural. Sua estrutura curricular - por linhas de pesquisa, unidades temáticas e unidades de aprendizagem - é visualizada na tabela 2.

TABELA 2 - DISTRIBUIÇÃO DAS DISCIPLINAS DO CURSO OFERECIDO PELA PUC-PR POR UNIDADES DE APRENDIZAGEM E UNIDADES TEMÁTICAS DE ACORDO COM AS LINHAS DE PESQUISA

\begin{tabular}{|c|c|c|}
\hline Linhas de pesquisa & Unidades Temáticas & Unidades de Aprendizagem \\
\hline Fundamentos de Bioética & $\begin{array}{l}\text { Bases Epistemológicas da } \\
\text { Bioética } \\
\text { Bioética e Direitos Humanos } \\
\text { Bioética e Pluralismo } \\
\text { Ética Aplicada e Bioética }\end{array}$ & $\begin{array}{l}\text { Epistemologia; Ética; Conceitos e história da } \\
\text { bioética; } \\
\text { Bioética, Sociologia e Direito; } \\
\text { Teologia e Bioética; Escolas de bioética; } \\
\text { Fundamentos da Bioética; Bioética e Ensino; } \\
\text { Comitês de Bioética; }\end{array}$ \\
\hline $\begin{array}{l}\text { Situações Emergentes em } \\
\text { Bioética }\end{array}$ & $\begin{array}{l}\text { Bioética Ambiental e Proteção } \\
\text { Animal } \\
\text { Ética e Biotecnociência } \\
\text { Ética em Pesquisa }\end{array}$ & $\begin{array}{l}\text { Bioética e reprodução Assistida; Tópicos especiais } \\
\text { em bioética; Bioética e Genética; } \\
\text { Ética em Pesquisa; }\end{array}$ \\
\hline $\begin{array}{l}\text { Situações Persistentes em } \\
\text { Bioética }\end{array}$ & $\begin{array}{l}\text { Bioética e Atenção em Saúde } \\
\text { Bioética Social }\end{array}$ & $\begin{array}{l}\text { Bioética Clínica; Bioética e Início da Vida; A morte e } \\
\text { os cuidados no fim da vida; Bioética e Saúde } \\
\text { Mental; } \\
\text { Saúde Pública; Saúde e Sociedade; }\end{array}$ \\
\hline Outras & brática multidisciplinar em hospi & ; Metodologia Científica; Monografia. \\
\hline
\end{tabular}




\subsubsection{Curso de Especialização em Bioética da Pontifícia Universidade Católica do Rio Grande do Sul}

A Pontifícia Universidade Católica do Rio Grande do Sul (PUC-RS), instituição pioneira na promoção da discussão acadêmica e social da bioética, por meio do Instituto de Bioética oferece o curso de pós-graduação lato sensu em bioética com vistas a suprir a necessidade e a demanda para a formação de pesquisadores e profissionais interessados no desenvolvimento de fundamentos teóricos, proposta e soluções eticamente corretas nos campos tecnocientíficos e social, bem como na promoção de políticas públicas eticamente adequadas.

É considerada a primeira instituição brasileira que teve a iniciativa de estruturar uma programação acadêmica com o intuito de preparar os profissionais de saúde para lidar com os conflitos em bioética ${ }^{46}$.

O curso de especialização em bioética da PUC-RS tem como proposta oferecer aos profissionais de todas as áreas um espaço interdisciplinar de discussões capaz de prover aos estudantes condições de construir o conhecimento necessário para fundamentar seus argumentos e reconhecer os argumentos de outras áreas afins, com o intuito de orientá-los e capacitá-los nas tomadas de decisão.

De acordo com a concepção pedagógica do curso, esta proposta parte do entendimento de que as relações contemporâneas entre biologia, medicina, ética e direito têm sido exploradas de modo significativo por meio da bioética, compreendida como um campo de convergência multidisciplinar de reflexão que visa à construção de conhecimento, ao desenvolvimento de pesquisa e que permite a proposição de políticas, condutas e decisões adequadas, respeitando a dignidade dos seres humanos, da vida em geral e do meio ambiente.

Segundo o projeto pedagógico do curso, esta problemática, de reconhecida importância nos dias atuais, exige de cada cidadão responsável, um aprimoramento para a identificação, discussão e resolução dos conflitos morais nela existentes e suas repercussões éticas, jurídicas e sociais.

O curso conta com um corpo docente formado por dezoito professores dentre os quais se encontram onze do gênero masculino e sete do gênero 
feminino de um total de dezesseis doutores e dois mestres. $O$ curso até 0 momento concluiu uma turma de especialistas em bioética no ano de 2009 e a tabela 3 identifica a estrutura curricular adotada.

TABELA 3 - DISTRIBUIÇÃO DAS DISCIPLINAS DO CURSO OFERECIDO PELA PUC-RS POR UNIDADES DE APRENDIZAGEM E UNIDADES TEMÁTICAS DE ACORDO COM AS LINHAS DE PESQUISA

\begin{tabular}{|c|c|c|}
\hline Linhas de pesquisa & Unidades Temáticas & Unidades de Aprendizagem \\
\hline \multirow[t]{5}{*}{ Fundamentos de Bioética } & $\begin{array}{lll}\text { Bases } & \text { Epistemológicas } & \mathrm{da}\end{array}$ & Fundamentos Filosóficos da Bioética; \\
\hline & Bioética & \\
\hline & Bioética e Direitos Humanos & \\
\hline & Bioética e Pluralismo & \\
\hline & Ética Aplicada e Bioética & Fundamentos da Bioética; \\
\hline \multirow{4}{*}{$\begin{array}{l}\text { Situações Emergentes em } \\
\text { Bioética }\end{array}$} & Bioética Ambiental e Proteção & Bioética e Animais; Bioética e Meio Ambiente; \\
\hline & Animal & \\
\hline & Ética e Biotecnociência & Temas emergentes de bioética; \\
\hline & Ética em Pesquisa & Pesquisa com seres humanos; \\
\hline \multirow{4}{*}{$\begin{array}{l}\text { Situações Persistentes em } \\
\text { Bioética }\end{array}$} & Bioética Clínica & Bioética Clínica; Bioética e início da vida humana; \\
\hline & & Bioética e final da vida humana; \\
\hline & Bioética e Atenção em Saúde & \\
\hline & Bioética Social & \\
\hline Outras & \multicolumn{2}{|c|}{ Monografia e Publicação; Seminários de conclusão. } \\
\hline
\end{tabular}

\subsubsection{Curso de Especialização em Ética Aplicada e Bioética do Instituto Fernandes Figueira - Fundação Oswaldo Cruz}

O Instituto Fernandes Figueira vinculado à Fiocruz tem sede no Rio de Janeiro e possui vasta experiência na formação e capacitação de recursos humanos nas áreas stricto e lato sensu. A instituição se destaca na pósgraduação lato sensu com os programas de residência médica desde 1978 e de enfermagem desde 1987. Oferece também cursos de especialização em áreas clínicas estratégicas da assistência à saúde da criança em níveis de média e alta complexidade. Tem proporcionado significativa contribuição na área da reflexão bioética em sua interface com a saúde pública ${ }^{46}$.

O curso de especialização em Ética Aplicada e Bioética foi oferecido entre 2002 e 2010 com nove turmas concluídas, num total de 146 alunos e 104 monografias defendidas.

O curso teve por objetivo formar profissionais aptos para atuar junto a Comitês de Ética em Pesquisa, Comitês de Bioética Hospitalar, no ensino e na 
pesquisa e tem como concepção pedagógica estimular o senso crítico de profissionais capazes de debater em várias instâncias as implicações morais do progresso tecnológico nos seres humanos, no meio ambiente e na sociedade, assim como as antigas questões sanitárias ou de bioética "cotidiana". Destaque para a ênfase dada às peculiaridades que se revestem o contexto socioeconômico e cultural brasileiro e à necessidade de desenvolvimento de uma Bioética Latino-americana.

O curso era constituído, basicamente, de quatro módulos e o conteúdo programático estava dividido em Unidades de Aprendizagem conforme os temas abaixo:

Módulo I: Fundamentos, definições e métodos em ética, ética aplicada e bioética com 45 horas-aula;

Módulo II: Macroética - meio ambiente, sistemas de saúde, sociedade e tecnologias com 60 horas-aula distribuídas;

Módulo III: Microética - o sujeito de pesquisa e o sujeito do tratamento com 105 horas-aula;

Módulo IV: Pesquisa em Bioética com carga horária de 150 horas-aula.

No primeiro módulo eram ministradas disciplinas que objetivavam propiciar ao aluno uma base teórica-conceitual, instrumentalizando-o para o entendimento das questões propostas nas etapas seguintes. No segundo eram enfatizadas as questões relacionadas à macroética, no qual se abordava os aspectos relativos ao meio ambiente, à justiça sanitária e à iniquidade social, e aos avanços tecnológicos.

No terceiro módulo eram estudadas as problemáticas envolvidas no que se denomina microética, isto é, o impacto e as implicações morais de determinadas aplicações científicas no campo da saúde com o objetivo de dar subsídios às discussões e temáticas do dia a dia dos hospitais. No último módulo era ofertada a disciplina de metodologia da pesquisa e as principais linhas a serem desenvolvidas no Brasil referente à Bioética, instrumentalizando o aluno a elaborar sua monografia de conclusão do curso.

As disciplinas eram ministradas por meio de aulas expositivas, seminários, debates, discussão de textos, estudos de casos, painéis e dinâmicas de grupo. Os alunos dispunham da infraestrutura física da Fundação Oswaldo Cruz e do acervo bibliográfico distribuído em três bibliotecas: 
Biblioteca do Instituto Fernandes Figueira, Biblioteca da Escola Nacional de Saúde Pública, Biblioteca de Manguinhos além do acesso à base de dados Medline e Lilacs e Rede Novell.

O corpo docente contava com nove professores (quatro do gênero masculino e cinco do gênero feminino) todos com titulação de doutor, servidores públicos estatutários vinculados a universidades e com ampla experiência acadêmica em ensino de pós-graduação, como também em pesquisa. O sistema de avaliação dos alunos durante o curso era realizado pela frequência, participação nos debates e trabalhos escritos e ao final do curso apresentação de monografia ou artigo científico para publicação a ser defendido perante banca examinadora de acordo com os temas desenvolvidos durante o curso.

Em 2010 tem início o programa de pós-graduação stricto sensu mestrado e doutorado em Bioética, Ética Aplicada e Saúde Coletiva em associação entre as seguintes instituições: Universidade Federal do Rio de Janeiro, Universidade Federal Fluminense, Universidade do Estado do Rio de Janeiro e Fundação Oswaldo Cruz. A estrutura curricular utilizada para a condução do curso é destacada na tabela 4.

TABELA 4 - DISTRIBUIÇÃO DAS DISCIPLINAS DO CURSO OFERECIDO PELO INSTITUTO FERNANDES FIGUEIRA POR UNIDADES DE APRENDIZAGEM E UNIDADES TEMÁTICAS DE ACORDO COM AS LINHAS DE PESQUISA

\begin{tabular}{|c|c|c|}
\hline Linhas de pesquisa & Unidades Temáticas & Unidades de Aprendizagem \\
\hline \multirow[t]{5}{*}{ Fundamentos de Bioética } & Bases $\quad$ Epistemológicas & Educação Moral e Ética; \\
\hline & Bioética & \\
\hline & Bioética e Direitos Humanos & Bioética e Deontologia; Bioética e Direito; \\
\hline & Bioética e Pluralismo & Escolas de Bioética; \\
\hline & Ética Aplicada e Bioética & $\begin{array}{l}\text { Ética e as Éticas Aplicadas; Ética Aplicada às } \\
\text { Relações de Trabalho; Estudos dirigidos; }\end{array}$ \\
\hline \multirow{4}{*}{$\begin{array}{l}\text { Situações Emergentes em } \\
\text { Bioética }\end{array}$} & Bioética Ambiental e Proteção & Ética Ambiental; Pesquisa com animais; \\
\hline & Animal & \\
\hline & Ética e Biotecnociência & $\begin{array}{l}\text { Bioética e Reprodução Assistida; Tecnociência e } \\
\text { Ética; }\end{array}$ \\
\hline & Ética em Pesquisa & Pesquisa com seres humanos; \\
\hline \multirow{4}{*}{$\begin{array}{l}\text { Situações Persistentes em } \\
\text { Bioética }\end{array}$} & Bioética Clínica & Bioética Clínica; Comitês de Bioética Hospitalar; \\
\hline & & \\
\hline & Bioética e Atenção em Saúde & Justiça e Alocação de Recursos; \\
\hline & Bioética Social & \\
\hline Outras & Metodologia da Pesquisa; Seminári & Avançados I e II; Monografia e Publicação; \\
\hline
\end{tabular}




\subsubsection{Curso de Especialização em Bioética do Instituto Oscar Freire da Faculdade de Medicina da Universidade de São Paulo}

O Núcleo de Estudos em Bioética (NEB) da Universidade de São Paulo tem como missão a realização de investigações científicas e ser o centro de referência da USP em pesquisa e divulgação de conhecimentos sobre a bioética. Criado em 2005 tem dentre as unidades envolvidas a Faculdade de Medicina, a Faculdade de Odontologia, a Faculdade de Direito, a Faculdade de Saúde Pública, a Escola de Enfermagem e o Instituto de Psicologia.

Vinculado ao Departamento de Medicina Legal, Ética Médica, Medicina Social e do Trabalho da Faculdade de Medicina da USP o Núcleo tem a finalidade, no âmbito institucional e acadêmico, de agregar professores e pesquisadores da área de bioética e de formar e capacitar pessoal para desenvolver pesquisas e estudos transdisciplinares, introduzindo ainda novas metodologias de ensino.

Dentre as ações desenvolvidas merece destaque a prestação de serviço à comunidade com cursos de formação e atualização para estudantes e professores de diferentes graus de ensino (médio e superior) disseminando informação e estimulando o debate ético e bioético. Como exemplos destas iniciativas podem ser citados o projeto "Ensino de Bioética no Ensino Médio" desenvolvido em parceria com a Faculdade de Educação da USP e o curso de especialização em bioética, inicialmente coordenado pelo Prof. Dr. Marco Segre. O quadro de pesquisadores do NEB é constituído por treze professores doutores, todos vinculados a Universidade de São Paulo e é conhecido como sendo a escola da bioética de reflexão autônoma ou bioética autonomista, desenvolvida pelo professor Marco Segre e Claúdio Cohen ${ }^{46}$.

Atualmente o curso de especialização conta com seis turmas já concluídas e uma em andamento. De acordo com a proposta pedagógica, o curso tem como um de seus objetivos situar estudantes e profissionais entre ética e ciência, conscientizando-os para o fato de que a reflexão bioética precede qualquer norma, não podendo existir parâmetros seguros que possam ser utilizados como guias em todas as ações e questões cotidianas.

De acordo com a tabela 5, a seguinte estrutura curricular é adotada pelo curso: 
TABELA 5 - DISTRIBUIÇÃO DAS DISCIPLINAS DO CURSO OFERECIDO PELO INSTITUTO OSCAR FREIRE POR UNIDADES DE APRENDIZAGEM E UNIDADES TEMÁTICAS DE ACORDO COM AS LINHAS DE PESQUISA

\begin{tabular}{|c|c|c|}
\hline Linhas de pesquisa & Unidades Temáticas & Unidades de Aprendizagem \\
\hline \multirow[t]{5}{*}{ Fundamentos de Bioética } & Bases $\quad$ Epistemológicas & Introdução à Filosofia da Ciência; Introdução ao \\
\hline & Bioética & Estudo da Bioética; Dilemas em Bioética; \\
\hline & Bioética e Direitos Humanos & \\
\hline & Bioética e Pluralismo & \\
\hline & Ética Aplicada e Bioética & $\begin{array}{l}\text { Fundamentos da Bioética; Bioética em Saúde e } \\
\text { Trabalho; }\end{array}$ \\
\hline \multirow{4}{*}{$\begin{array}{l}\text { Situações Emergentes em } \\
\text { Bioética }\end{array}$} & Bioética Ambiental e Proteção & \\
\hline & Animal & \\
\hline & Ética e Biotecnociência & Bioética e Biotecnologia; Bioética e Genética; \\
\hline & Ética em Pesquisa & $\longrightarrow$ \\
\hline \multirow{5}{*}{$\begin{array}{l}\text { Situações Persistentes em } \\
\text { Bioética }\end{array}$} & Bioética Clínica & Bioética Clínica; Bioética e Início da vida; Bioética e \\
\hline & & a interrupção da vida; Bioética e o fim da vida; \\
\hline & Bioética e Atenção em Saúde & Bioética e a Pessoa Deficiente; Bioética e Alocação \\
\hline & & de Recursos em Saúde; \\
\hline & Bioética Social & - \\
\hline Outras & Metodologia na Ciência; Seminários & de Bioética; Trabalho de Conclusão de Curso. \\
\hline
\end{tabular}

Fonte: pesquisa do autor, 2015.

\subsubsection{Curso de Especialização em Bioética da Universidade Estadual de Londrina}

A partir de uma metodologia multidisciplinar e plural com ênfase no diálogo e no aprofundamento das questões éticas suscitadas pela tecnociência contemporânea, apesar de ocuparem um lugar importante na pauta bioética, o curso abrange um campo que vai para além da deontologia e ética médica incluindo questões relativas à manipulação e intervenção da vida humana (engenharia genética), à preservação das espécies não humanas, assim como às questões relativas à gestão da biosfera, à ecoética ou ética ambiental.

Com nove turmas concluídas o curso de especialização em bioética da Universidade Estadual de Londrina teve como objetivo oferecer formação em bioética a profissionais de diversas áreas diretamente envolvidos com os avanços da ciência e tecnologia, que têm reflexo sobre a vida da humanidade, exigindo indagações de natureza ética.

Oferecido na modalidade presencial, inicialmente com uma carga horária de 360 horas e posteriormente 420 horas-aula a partir de 2007, o curso contava com um corpo docente composto por cinco professores doutores, dois 
mestres e um especialista. Os cursos foram realizados entre os anos de 2000 a 2008 com um total de 140 alunos concluintes e 140 monografias defendidas.

Como resultado das monografias de conclusão dos cursos, quatro livros foram organizados "Bioética: estudos e reflexões" publicados pela editora UEL entre 2000 e 2003.

O curso possuía como eixo condutor a estrutura curricular destacada na tabela abaixo.

TABELA 6 - DISTRIBUIÇÃO DAS DISCIPLINAS DO CURSO OFERECIDO PELA UNIVERSIDADE ESTADUAL DE LONDRINA POR UNIDADES DE APRENDIZAGEM E UNIDADES TEMÁTICAS DE ACORDO COM AS LINHAS DE PESQUISA

\begin{tabular}{|c|c|c|}
\hline Linhas de pesquisa & Unidades Temáticas & Unidades de Aprendizagem \\
\hline \multirow[t]{5}{*}{ Fundamentos de Bioética } & Epistemológicas & Fundamentos de Ética; \\
\hline & Bioética & \\
\hline & Bioética e Direitos Humanos & Biodireito e Política; \\
\hline & Bioética e Pluralismo & \\
\hline & Ética Aplicada e Bioética & $\begin{array}{l}\text { Fundamentos da Bioética; Metodologias dos } \\
\text { processos decisórios em Bioética; Metodologia do } \\
\text { Ensino de Bioética; }\end{array}$ \\
\hline \multirow{4}{*}{$\begin{array}{l}\text { Situações Emergentes em } \\
\text { Bioética }\end{array}$} & Bioética Ambiental e Proteção & Bioética e Ecologia; \\
\hline & Animal & \\
\hline & Ética e Biotecnociência & Ciência, Tecnologia e Bioética; \\
\hline & Ética em Pesquisa & 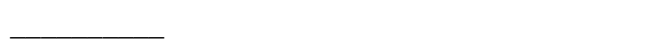 \\
\hline \multirow{4}{*}{$\begin{array}{l}\text { Situações Persistentes em } \\
\text { Bioética }\end{array}$} & Bioética Clínica & Tópicos Avançados em Bioética; \\
\hline & & \\
\hline & Bioética e Atenção em Saúde & Bioética na Saúde; \\
\hline & Bioética Social & - \\
\hline Outras & Iniciação à Pesquisa em Bioética; $\mathrm{N}$ & nografia. \\
\hline
\end{tabular}

Fonte: pesquisa do autor, 2015.

Todos os cursos possuem uma carga horária total de 360 horas conforme o estabelecido pela Resolução no 01 do CNE/CES de 08 de junho de 2007, dividida por módulos a cargo de um professor responsável em cada área temática delimitada. Destacam-se os cursos da UEL e do Instituto Oscar Freire que, de acordo com os projetos pedagógicos, apresentaram carga horária com um total de 420 horas/aula. A carga horária de cada módulo varia de 15 a 60 horas/aula. 


\subsubsection{Análise comparativa entre a proposta do curso de especialização da Universidade de Brasília e as demais}

Nesse momento se realiza o comparativo entre os cursos de especialização em bioética selecionados e o curso de especialização da UnB, particularmente no que se refere à fundamentação teórica adotada pelos cursos. Para esta análise é preciso ratificar o aporte fundamental da Cátedra Unesco de Bioética como responsável pela visibilidade e reconhecimento nacional e internacional dos trabalhos desenvolvidos pelos alunos que frequentaram os cursos ministrados pela instituição.

Infere-se dos cursos de especialização analisados no presente trabalho um enfoque para o ensino da bioética associado à área biomédica com predomínio para o uso do principialismo como suporte teórico para a problematização da discussão. Percebe-se a reduzida inclusão e associação da bioética aos problemas sociais e de saúde pública que persistentemente afligem o cotidiano de nosso país, carente de uma visão crítica e contextualizada.

Permanece a insistente característica restrita às implicações e desafios éticos dos avanços científicos e biotecnológicos para a área biomédica - a bioética clínica. Não com o intuito de diminuir a importância desta discussão para a bioética, mas com a proposta de ampliar o debate é que se faz a presente consideração.

A década de 90 foi marcada pelas principais críticas à teoria principialista confirmando sua insuficiência como teoria universal para os diferentes contextos e realidades nos mais distintos países e regiões. Tais críticas proporcionaram a inclusão na pauta bioética de temas antes pouco explorados. A consequência desta limitação teórica tem sido a crescente e progressiva incorporação da DUBDH como referencial no nível acadêmico haja vista a publicação de artigos científicos tendo a declaração como fundamentação teórica.

Percebe-se nos cursos que utilizam o principialismo como referência e restringem a discussão bioética à área biomédica um viés acentuadamente reducionista. E é nesse aspecto que reside o principal diferencial do curso de especialização da UnB que, embora também faça menção ao principialismo 
reservando duas aulas no módulo "Fundamentos de Bioética", tem como característica a adoção da DUBDH como referencial teórico do curso em suas últimas edições.

Para parte dos alunos do curso da UnB, a duração do mesmo é considerada curta diante da multiplicidade de temas e perspectivas que a bioética aborda, e também é relatada a necessidade de incorporação de metodologias voltadas à prática da bioética bem como o aprofundamento e articulação de alguns módulos ${ }^{84}$.

Os cursos de especialização analisados têm como características em comum serem oferecidos na modalidade presencial e aberto a todos os interessados com curso superior em diferentes áreas do conhecimento, sem restrições de qualquer natureza. Pode-se afirmar que a bioética é tida como conhecimento aplicável a todas as profissões, principalmente às da área da saúde e, dessa maneira, é atribuída fundamental importância à utilização de seus referenciais teóricos e práticos para uma atuação profissional consciente e crítica ${ }^{29}$.

Gomes e cols. ${ }^{84}$ ao realizarem uma análise da primeira década do curso de especialização ofertado pela Cátedra Unesco de Bioética da UnB identificaram alunos provenientes de nada menos que vinte carreiras diferentes, ratificando a perspectiva interdisciplinar inerente ao campo de atuação da bioética. $\mathrm{Na}$ área biomédica foram referidas oito carreiras: enfermagem, odontologia, medicina veterinária, farmácia, biomedicina, medicina, biologia e fisioterapia. Na área de Humanas foram identificadas doze graduações: administração, história, filosofia, direito, comunicação social, sociologia, antropologia, educação física, economia, letras, biblioteconomia e psicologia ${ }^{84}$.

Desse modo, como a bioética possui dentre suas características a pluralidade e o estímulo ao debate, observa-se nos cursos uma estrutura curricular que possibilita e permite a troca de experiências entre diversas opiniões e pontos de vistas sobre a extensa temática bioética, inerente a distintas áreas de atuação.

Nesse sentido, é preciso considerar que o processo de formação profissional requer uma abordagem multi e interdisciplinar no qual os conteúdos se interpenetram e se comunicam em detrimento do predomínio do 
enfoque racionalista, com o intuito de associar o pensar ao agir e fazer, socialmente comprometido e engajado. Tal abordagem reivindica o domínio de conhecimentos científicos e técnicos é verdade, mas igual consideração deve ser dada à capacidade de análise e de reflexão a fim de um posicionamento capaz de modificar as condições de vida e saúde ${ }^{29}$.

Para Prado e Garrafa ${ }^{29}$, a formação profissional deve proporcionar o desenvolvimento de competências e habilidades técnicas, éticas e humanísticas que permitam uma atuação que observe e respeite os valores individuais e coletivos - e os aspectos culturais de uma determinada comunidade, identificando suas reais necessidades e demandas.

Dessa forma, a bioética se apresenta com o objetivo de propiciar o exercício do reconhecimento dos conflitos morais, a análise crítica das implicações da incorporação das novas tecnologias, a responsabilidade social e a obrigação moral na tomada de decisões relacionadas à vida humana e à natureza $^{66}$.

Percebe-se, de acordo com as tabelas apresentadas, a heterogeneidade de enfoques desenvolvidos em cada curso. Pode-se inferir que a liberdade da estrutura curricular é determinada conforme a característica da instituição e também do coordenador responsável.

Este aspecto nos remete ao indagamento: qual o conteúdo adequado para um curso de especialização em bioética? Sobre este aspecto não é definido pela Resolução CNE/CES no 01 qualquer tipo de conteúdo obrigatório que deva ser incluído.

De acordo com as ementas analisadas, os cursos contemplam, em maior ou menor profundidade, os conteúdos abordados nas linhas de pesquisa adotadas como referencial metodológico, guardando similaridades aos conteúdos da estrutura do curso oferecido pela Universidade de Brasília.

No entanto, em suas últimas edições, o curso da UnB tem utilizado como referencial teórico os princípios da Declaração Universal sobre Bioética e Direitos Humanos da Unesco e a distribuição dos temas pelas disciplinas tem como base os artigos da Declaração - especialmente o capítulo referente aos seus 15 "princípios", que vão do artigo 3 ao 17 - e o Core Curriculum também elaborado pela Unesco com base na mesma Declaração ${ }^{93}$. 
Vale ressaltar a unidade temática "Ética aplicada e Bioética" que possui a maior variedade de unidades de aprendizagem encontrada nas ementas e planos de ensino, o que permite inferir que a reflexão e a problematização de diferentes moralidades aplicadas a práticas sociais específicas para a solução de conflitos e consequente decisão ética sejam os mais explorados pelos cursos.

Por outro lado, observa-se a ausência de unidades de aprendizagem na temática "Bioética Social". Tal constatação deve-se ao fato da ainda recente difusão e incorporação da DUBDH, cujos princípios são utilizados como referencial teórico para esta unidade temática.

A Declaração Universal sobre Bioética e Direitos Humanos, homologada em outubro de 2005, ocupa-se dos valores fundamentais à bioética, tais como a dignidade humana e os direitos humanos, a autonomia e a responsabilidade individual, o consentimento, o respeito pela vulnerabilidade humana e integridade pessoal, a confidencialidade, a igualdade, a justiça, a equidade, bem como de temas relacionados ao preconceito e a responsabilidade para com as gerações futuras e para com o meio ambiente ${ }^{49}$, temática que vem sendo paulatinamente incluída na pauta bioética.

Segundo Garrafa ${ }^{93}$, a DUBDH trata-se de um acordo internacional que tem por finalidade agrupar os princípios éticos que norteiam o respeito à dignidade humana relacionada, além das questões biomédicas e biotecnológicas, às questões sanitárias, sociais e ambientais, aspectos de grande interesse para as nações pobres e/ou desenvolvimento.

Merece destaque a abordagem teológica trabalhada por algumas instituições. Esta característica é explicada por três das instituições analisadas serem de origem católica e pela peculiaridade de um dos cursos incluir na formação a temática da pastoral da saúde. De acordo com Finkler ${ }^{37}$, "mesmo que a instituição seja confessional e professe sua fé e, portanto, também sua ética religiosa, a necessidade de se trabalhar a ética civil e laica no campo da saúde e da vida - a bioética - mantém-se imprescindível para a formação profissional na área". (p.155)

Dentre os principais desafios que se insere para a bioética no contexto cultural contemporâneo, destaca-se a procura de um método que seja capaz de superar a ruptura entre a cultura científica e a cultura humanística e propor 
um novo elo entre elas a fim de produzir novas possibilidades de conhecimento $^{94}$.

A bioética, considerada como a área mais produtiva e dinâmica das éticas aplicadas, traz consigo a dificuldade - e por que não dizer a impossibilidade - de se dominar todo o seu campo de abrangência devido à multiplicidade dos dialetos e idioletos bioéticos inerentes a este campo do conhecimento ${ }^{95}$.

Uma perspectiva que se apresenta para a bioética é a superação dos reducionismos a ela associados. Por um lado, é preciso desvincular seu campo de atuação restrito à ética biomédica, limitada às ciências da saúde e não às ciências da vida de modo geral e ao meio ambiente. Por outro, também se faz necessária a ampliação do seu referencial teórico para além do principialismo buscando novos modelos que lhe deem sustentação ${ }^{96}$.

Nesse aspecto o curso oferecido pela UnB se destaca por trabalhar uma bioética direcionada, além dos temas biomédico-biotecnológicos, também e muito especialmente às questões sanitárias, sociais e ambientais sob a ótica coletiva e pública, o que o diferencia substancialmente dos demais cursos.

Não com o intuito de negação do pragmatismo principialista, mas com o incômodo de seu limitado foco de ação para com os problemas morais que afligem nossa realidade é que os bioeticistas brasileiros, envolvidos com os movimentos sociais, a Teologia da Libertação e a Reforma Sanitária, revisaram o pensamento hegemônico até então no país. É importante mencionar três escolas do pensamento bioético brasileiro que emergiram no contexto brasileiro nestes últimos anos, analisadas inicialmente por Oliveira e cols. ${ }^{27}$ em 2005 :

.Bioética de Proteção;

.Bioética de Intervenção;

.Bioética e Teologia da Libertação;

Apresentam-se como características comuns a defesa do vulnerado, o exercício do diálogo e a defesa da dignidade da pessoa humana, características diferentemente trabalhadas e aprofundadas pelos autores de cada pensamento ${ }^{27}$.

É oportuno resgatar, ainda que sucintamente, os principais enfoques dessas escolas do pensamento bioético brasileiro: 
Bioética de Proteção: fundamenta-se no fato de que a "proteção do vulnerado contra as situações que promovem 0 adoecimento $e$ a implementação de ações que promovam sua autonomia com o intuito de alcançar maior qualidade de vida" ${ }^{97}$ (p.166) é dever do Estado. Tem como precursores os professores Fermin Roland Schramm e o chileno Miguel Kottow.

De acordo com os autores as características do princípio da proteção são: "a gratuidade, não há um compromisso prévio de assumir uma atitude protetora; a vinculação, a atitude, uma vez assumida, torna-se um dever; a segurança efetiva das necessidades do afetado" ${ }^{27}$ (p.373).

Pode ser definida como uma bioética laica que assume a tarefa de proteção dos mais desamparados com o objetivo de alcançar a justiça social, e de proteção da integridade física e patrimonial de todos os indivíduos que se encontram em território nacional.

Bioética de Intervenção: no âmbito público enfatiza a responsabilidade do Estado no que tange à solução dos dilemas persistentes e a defesa das populações mais vulneráveis, tendo como base uma proposta utilitarista e consequencialista - o "consequencialismo solidário". Abarca também em seu campo de atuação a finitude dos recursos naturais, o estudo da corporeidade referente às sensações de prazer e dor, e mais recentemente, o conceito de colonialidade ${ }^{27}$.

No âmbito privado indica "necessidade de fomentar o empoderamento, sustentar a libertação e garantir a emancipação dos sujeitos sociais com o objetivo de alcançar sua inclusão plena na dinâmica relacional da sociedade" ${ }^{\prime 97}(p .170)$ e a contextualização dos conflitos éticos. Apresentam-se como idealizadores o professor Volnei Garrafa e Dora Porto.

Bioética da Teologia da Libertação: propõe a existência de uma "mística" na bioética, entendendo esta mística como as razões e motivações ocultas que sustentam os critérios, argumentações, proposta de atitudes e normas na bioética. Tem como objetivo essencial realizar o diálogo entre ciência e religião e propor uma interface entre os conceitos teológicos ocidentais católicos e os da bioética ${ }^{27}$.

Divide as questões bioéticas em três dimensões inter-relacionadas: mini-sociais, midi-sociais e macro-sociais. Defende a interlocução da teologia 
com o discurso científico e sustenta que "a reflexão da realidade é por demais complexa para ser compreendida por uma só forma de percepção do saber"97 (p.174). Tem como seu principal representante o teólogo Marcio Fabri dos Anjos.

Vale ressaltar que as iniciativas propostas ainda se encontram em construção, porém coincidem em relação ao respeito ao pluralismo moral e a defesa dos interesses das pessoas mais frágeis e vulneráveis e, de acordo com Garrafa ${ }^{98}$, não devem ser entendidas como "afronta" ou até mesmo uma "desobediência científica" às teorias tradicionalmente constituídas, mas sim como a intenção de busca contextualizada de respostas morais adequadas aos problemas inerentes à realidade brasileira - a exclusão social e a defesa da cidadania, suas fontes básica de inspiração.

A reflexão bioética brasileira, com originalidade e identidade próprias, propõe-se a compreender e a resolver antigos e novos desafios surgidos do avanço científico com repercussões na área da saúde pública e na pesquisa biomédica, a partir da realidade social, econômica, política e cultural do continente latino-americano, um contexto de injustiça e exclusão social ${ }^{46}$.

Não se observou explicitamente menção a estas escolas de pensamento bioético brasileiras em nenhuma das ementas analisadas, todavia é muito provável que no desenvolvimento dos diferentes módulos ocorra a abordagem particularizada de uma ou mais destes pensamentos de acordo com a temática abordada.

A análise da formação acadêmica do corpo docente foi realizada conforme as informações encontradas nas ementas e planos de ensino disponibilizados pelos coordenadores, e confrontadas pelo acesso ao currículo lattes dos docentes via endereço eletrônico da Capes. Prioritariamente o corpo docente dos cursos é formado por professores doutores, embora se encontrem mestres e também especialistas compondo o quadro, com relativa experiência em bioética. Todos os cursos seguem o que a Resolução ㄲo 01 do CNE/CES preconiza, ou seja, que no mínimo $50 \%$ do corpo docente seja formado por mestres e doutores ${ }^{19}$.

Sobre a formação docente e o ensino de conteúdos de ética, Ramos ${ }^{25}$ aponta "ser destinado quase que com exclusividade a poucos professores, nem sempre com formação ou experiência específica" (p.56). No entanto, para 
lograr êxito no estímulo à construção de conhecimentos, no desenvolvimento de atitudes e valores, o ensino da bioética deve-se adequar às diferentes metodologias e formas de avaliação, associadas a uma estrita ética docente.

Estas peculiaridades exigem dos professores que se dedicam ao ensino da bioética a capacidade de transitar entre as perspectivas clínica e jurídica desde uma fundamentação filosófica singular da bioética sem, no entanto, se distanciarem das circunstâncias culturais e sociais inerentes ao seu próprio contexto. Este aspecto requer do docente uma permanente atualização ${ }^{80}$.

Quanto aos métodos de ensino-aprendizagem adotados pelos cursos, observou-se uma abordagem tradicional por parte das instituições, com aulas expositivas e em pequenos grupos, sem referência a um método diferenciado. Em relação ao curso da UnB, o curso também não segue um padrão específico de ensino-aprendizagem, variando de acordo com o professor e também com a disciplina em questão.

No curso de especialização da UnB, as disciplinas de características mais teóricas e conceituais são desenvolvidas por meio de aulas magistrais com auxílio de projeções e abertura para o debate em grupo, sustentados por textos de diferentes autores, distribuídos previamente aos alunos e relacionados aos temas abordados ${ }^{92}$. Nas de características mais temáticas são utilizados filmes seguidos por trabalhos em pequenos grupos com posterior apresentação para o restante da turma. Em outras ocasiões tribunais simulados são organizados, nos quais grupos diferentes devem defender posições morais opostas com relação ao mesmo conflito em análise ${ }^{92}$.

Para Junqueira e cols. ${ }^{66}$, a utilização da internet surge como uma proposta de complementação do estudo no processo de ensino-aprendizagem da bioética. Os fóruns de discussão podem ser considerados importantes instrumentos de apoio para a aproximação entre teoria e prática para o ensino da bioética, ao permitir o compartilhamento de opiniões entre alunos e professores. Contudo, é necessário prudência quanto às potencialidades e limitações do ambiente virtual a fim de manter a integração entre alunos e tutores $^{66}$.

A Aprendizagem Baseada em Problemas também é referenciada como alternativa viável favorecedora do desenvolvimento moral dos profissionais, 
promovendo a interação de saberes e o estímulo ao pensamento crítico e reflexivo $^{72}$. Observou-se menção a esta metodologia de ensino no curso de especialização da Universidade de Estadual de Londrina.

Pode-se inferir, de acordo com os dados encontrados, que os cursos de especialização em bioética podem ser um instrumento que propicie uma transformação na vida profissional e cotidiana, entretanto, é importante que o seu ensino se dê para além das formas tradicionais de transmissão de conteúdos didáticos com a definitiva incorporação da dimensão social na práxis individual e coletiva ${ }^{84}$.

Como atestaram Gomes e cols. ${ }^{84}$ no curso de especialização da UnB, para $94,45 \%$ dos estudantes o contato com a bioética trouxe conhecimento que foi agregado à dimensão profissional na utilização nos princípios e conceitos da área e, para $80,55 \%$ a influência da bioética se estendeu à vida cotidiana proporcionando reflexões para o dia a dia norteadas por parâmetros éticos na dimensão social, tornando-as pessoas mais preocupadas em fazer a ponte entre teoria e prática ${ }^{84}$.

Dessa forma, o delineamento dos projetos pedagógicos não deve se furtar do compromisso de promover a competência do desenvolvimento intelectual e profissional autônomo e permanente. Devem possibilitar aos estudantes a continuidade do processo de formação acadêmica, a fim de prepará-los para o enfrentamento dos desafios impostos pelas rápidas transformações da sociedade, do mercado de trabalho e das condições de exercício profissional. Tarefa cada vez mais exigida pela sociedade contemporânea a coordenadores e docentes envolvidos com um processo educativo mais humanizado ${ }^{99}$.

Apesar da análise documental permitir visualizar um panorama de como tem se estruturado o ensino da pós-graduação lato sensu em bioética, carece de uma visão particular de quem vivencia e acompanha o desenvolvimento do curso do qual se poderá tirar conclusões mais detalhadas.

Nesse particular, com o intuito de aprofundar os dados apurados, foi indispensável também que a presente pesquisa se debruçasse, dentre outros objetivos, sobre os conteúdos ministrados nos diferentes cursos, especialmente na importância dada pelos coordenadores ao principialismo. Este aspecto é de relevante interesse, pelas peculiaridades que a bioética desenvolvida no Brasil 
e na América Latina vem conquistando, no sentido de procurar rumos próprios, mais livres e não umbilicalmente ligados às correntes teóricas vindas dos países do norte.

É de fundamental importância conhecer os significados que as pessoas atribuem às suas experiências do mundo social e como compreendem seu contexto. Facilita assim a interpretação dos fenômenos sociais (interações, condutas) em termos dos sentidos que as pessoas Ihes atribuem. Para a bioética, que busca a essência moral que determina escolhas e comportamentos, a pesquisa qualitativa produz informações muito mais valiosas e de maior aplicação para a análise dos fenômenos que se pretende conhecer ${ }^{100}$.

Nesse sentido, é preciso considerar a limitada contribuição dos projetos pedagógicos observados nos planos de ensino dos cursos para análise da formação profissional na pós-graduação lato sensu. Devido ao fato do processo de formação envolver uma dinâmica ampla e complexa, tornou-se necessário o aprofundamento da questão por meio de entrevistas semi-estruturadas com os coordenadores $^{25}$, assunto do próximo momento deste estudo.

\subsection{Segundo momento - Entrevistas semi-estruturadas}

Após o acesso às ementas e planos de ensino procedeu-se à exploração e análise a fim de selecionar aspectos relevantes a serem abordados na categorização das áreas temáticas e para estruturar e subsidiar o instrumento para a coleta de dados - o roteiro da entrevista semi-estruturada.

\subsubsection{Do perfil dos entrevistados}

O grupo formado foi composto de sete entrevistados, sendo seis coordenadores de cursos de especialização e um professor selecionado com atuação como coordenador em edições passadas, conforme mencionado anteriormente.

Para o delineamento do perfil dos entrevistados foram formuladas sete perguntas para identificação do gênero, idade, formação profissional, tempo de 
formado, formação acadêmica, formação em bioética e tempo de atuação em bioética.

Dos sete entrevistados, cinco eram do gênero masculino e dois do gênero feminino com as seguintes formações profissional: três médicos, um advogado, um biólogo, um teólogo e um pedagogo. Com relação ao tempo de formado, cinco possuíam mais de vinte anos e dois, entre onze e vinte anos de formados.

Quanto à formação acadêmica, todos os entrevistados possuíam titulação de mestre e doutor. Com relação à formação acadêmica em bioética, três relataram ter pós-doutorado em bioética, dois, doutorado, um mestrado, e um relatou não possuir formação em bioética, intitulando-se autodidata na área. O tempo de atuação em bioética foi de 11 a 20 anos para todos os entrevistados.

\subsubsection{As entrevistas}

A seguir, serão descritos e discutidos os resultados das sete entrevistas semi-estruturadas enviadas a cada um dos professores selecionados. A descrição das respostas observará a ordem estabelecida no roteiro definido no instrumento para a coleta de dados. Como a técnica de análise foi a Análise de Conteúdo - Análise Categorial/ Análise Temática, serão transcritas as Unidades de Registro (o tema) e as Unidades de Contexto (os segmentos da mensagem) de cada pergunta.

Para a preservação do sigilo das identidades dos participantes na análise dos resultados, os trechos das entrevistas realizadas com os coordenadores dos cursos foram identificados como Coordenador A, Coordenador B, Coordenador C, Coordenador D, Coordenador E, Coordenador F e Coordenador G, não seguindo a ordem anteriormente apresentada quando da análise documental dos cursos.

Nas cinco primeiras perguntas a área temática (tema) foi o perfil acadêmico dos cursos. Essa temática buscava analisar os objetivos dos cursos, se o conteúdo programático incluía correntes de pensamento e/ou teorias bioéticas nacionais, novas metodologias de avaliação e de ensinoaprendizagem e a formação acadêmica em bioética do corpo docente. 


\section{Qual o marco referencial adotado para a condução do curso e quais os objetivos do conteúdo programático?}

Esta pergunta pretendeu verificar se o curso oferecido priorizava os valores humanitários, o desenvolvimento moral e a capacidade de reflexão e autocrítica dos profissionais que procuravam pelo curso. Procurou-se identificar se em algum momento os entrevistados fariam referência aos princípios da DUBDH.

Os seguintes trechos são elucidativos sobre o entendimento dos entrevistados acerca do referencial teórico adotado no curso:

"A Bioética tem um cunho interdisciplinar, repleta de posicionamentos filosóficos e ideológicos e não é uma ética universalista da vida porquê está no olho do furacão, isto é, dos conflitos, dos debates e dos questionamentos. É um campo de conhecimentos, um conjunto de questões de dimensão ética, o que coloca em jogo valores a serem resolvidos por meio de escolhas, tendo sua origem no poder cada vez maior da intervenção biotecnocientífica no ser humano e nos outros seres vivos.(...) A discussão ética necessária e cada vez mais intensa, aponta para um novo referencial ético instigante e aos poucos, criam-se referenciais norteadores das ações. Entretanto, estamos longe de um consenso quanto ao que fazer diante desta nova era tecnológica que influi, sobremodo, nos indivíduos, nos costumes, na cultura, na filosofia, na prática clínica, nas instituições e nas investigações científicas. Ninguém deve se excluir de debater os novos problemas éticos que emergem todos os dias." (Coordenador A)

"Apresentamos aos estudantes correntes teóricas diversas, mas reforçamos que o pensamento em bioética não deve ser colonizado por marcos teóricos ou referenciais que lidam com realidades diversas aquela existente no Brasil ou na América Latina. Os conflitos morais enfrentados pelos brasileiros são perpassados por lógica própria: a dos coletivos. Mesmo que uma perspectiva individualista, neoliberalizante, consumista esteja se entranhando no pensamento da saúde pública, tentamos mostrar para os alunos que a Bioética deve fornecer uma alternativa.(...) Nessa perspectiva crítica é que o curso se sustenta." (Coordenador B)

Em nenhum momento das respostas houve menção à utilização dos princípios da DUBDH. A Declaração Universal sobre Bioética e Direitos Humanos se apresenta como um novo referencial ético que permite a utilização de referenciais norteadores de ação numa perspectiva crítica, anti-hegemônica, socialmente engajada e politicamente compromissada. Para Pires e Shimizu ${ }^{54}$ a DUBDH marca a evolução de uma bioética essencialmente filosófica e acadêmica para uma reflexão acerca dos problemas sociais, de saúde pública e ambiental, pauta ainda bastante presente no contexto latinoamericano. A publicação da DUBDH ratifica a importância da bioética como instrumento 
capaz de auxiliar na resolução de conflitos éticos que atentam contra os direitos humanos.

Dois dos entrevistados relataram não possuir um marco referencial específico adotado para todo o curso, conforme se pode observar:

"Diversos: cada disciplina do Curso tinha conteúdo programático específico." (Coordenador D)

"Não houve um marco referencial pré-definido e cada disciplina continha seus objetivos." (Coordenador E)

Com relação aos objetivos a serem alcançados com o conteúdo programático dos cursos importa transcrever os seguintes fragmentos de entrevista:

"Formar especialistas em Ética Aplicada e Bioética capazes de atuarem junto aos Comitês de Ética em Pesquisa, Comitês de Bioética Hospitalar, no ensino e na pesquisa." (Coordenador A)

"Situar os especializandos entre ética e ciência, conscientizando-os para o fato de que a reflexão bioética precede qualquer norma, não podendo existir parâmetros seguros para nos guiarem em todas as nossas ações. Atualizar os conhecimentos mais recentes em tecnologia na área da saúde e suas implicações éticas. Formar profissionais capazes de lidar com as teorias da bioética nas questões cotidianas." (Coordenador C)

\section{Quais as correntes / teorias éticas desenvolvidas no curso? Qual a sua análise a respeito do desenvolvimento de teorias bioéticas brasileiras no contexto mundial?}

Buscou-se com essa questão analisar se o curso enfatizava 0 referencial bioético principialista ou se abordava a bioética em sua pluralidade de referenciais teóricos e campos de reflexão, discutindo os conflitos e problemas de saúde e da prática profissional em sua interface com a ética.

Todos os entrevistados relataram fundamentos de ética e bioética como as principais bases para a condução dos cursos, embora um coordenador mencionou que não havia uma corrente específica que orientasse todo o curso. Os fragmentos abaixo ratificam esta percepção: 
"Noções básicas sobre o estudo e a evolução da Ética na filosofia desde Aristóteles até Kant. Principais correntes de pensamento (Ética teleológica, deontológica e utilitarista). (...) A questão dos fundamentos da ética. Conceituação de Ética Aplicada (ética das virtudes, neokantismo, utilitarismo de Singer, principialismo dos quatro princípios, princípios da qualidade de vida e da sacralidade da vida. Ética da responsabilidade de Hans Jonas)." (Coordenador A)

"Os cursistas passam por disciplinas que discutem fundamentos de ética (Deontologia, Ética de Virtudes, Utilitarismo, etc.) e em seguida frequentam disciplinas que contextualizam problemas do campo da saúde e da vida ao crivo do pensamento ético. Em seguida passam por disciplinas de fundamentação do pensamento bioético, onde são expostos a textos e aulas sobre diversas correntes de pensamento em bioética, como é o caso do Utilitarismo de Singer, a Ética do Cuidado, a bioética feminista, etc." (Coordenador B)

"Fundamentos de ética e bioética." (Coordenador F)

"O curso de especialização acolhia docentes de correntes diversas, não havia um controle nem direcionamento para uma única perspectiva." (Coordenador D)

Os entrevistados relataram conhecer as escolas de pensamento brasileiras e os autores responsáveis por elas. Sobre o desenvolvimento destas teorias no contexto mundial dois entrevistados se manifestaram de forma oposta, embora todos mencionaram que em algum momento do curso se fazia referência a tais teorias.

"Minha análise sobre as teorias bioéticas no contexto mundial só se pode dar olhando-se as publicações fora do Brasil. Penso que na América Latina ela tem alguma visibilidade, mas não ao ponto de formar uma escola de pensamento, já que não tem seguidores expressivos. Nos países desenvolvidos não vejo publicações e nem referencias nos artigos." (Coordenador A)

“... as bioéticas do sul, apesar de características teóricas um pouco distintas da dureza do pensamento europeu ou do modelo excessivamente biomédico norteamericano, não são bioética de segundo escalão. Têm seu lugar na diversidade de bioéticas. Principalmente por tratarem com mais propriedade dos problemas bioéticos que estão fora das pesquisas biomédicas ou da relação médico-paciente. Isso significa compreender que trata-se de bioética para maioria das pessoas que vivem no mundo: os excluídos, os vulneráveis, as vítimas de violências, etc. Acredito que é por isso que as escolas de pensamento brasileiras (prefiro me referir assim, já que não são teorias no sentido estrito) dão conta de problemas que afetam um contingente enorme de pessoas. Acho que é por isso que tem chamado atenção e se destacado internacionalmente." (Coordenador B)

"Os autores brasileiros foram estudados também, sem destaque específico para eles." (Coordenador D)

"São teorias em igual patamar hierárquico intelectualmente, porém mais adequadas à nossa realidade." (Coordenador E) 
"Bioética crítica, para situar a realidade da saúde no Brasil (...) a contribuição das percepções críticas brasileiras da Bioética sobre saúde pública parece consistente." (Coordenador F)

A par dos aspectos positivos proporcionados pela teoria principialista, é necessário abertura para novas perspectivas éticas que incorporem ao discurso cotidiano os aspectos sociais, também campo de reflexão e experiência moral, tendo em conta as limitações inerentes às incertezas e à complexidade dos problemas vivenciados ${ }^{25}$.

No que se refere à incorporação de teorias bioéticas de acordo com o contexto latinoamericano é importante destacar que a partir da década de 90 a bioética passa a ser compreendida como uma matriz interdisciplinar complexa ao abranger os aspectos jurídicos, sociológicos, filosóficos e teológicos permitindo, dessa forma, a introdução dos Direitos Humanos na pauta bioética. Esse período marca o fortalecimento do direito e a defesa da vida com a publicação da "Declaração sobre o Genoma Humano e os Direitos Humanos" pela Unesco em $1997^{101}$.

É no século XXI que a bioética latinoamericana se consolida com uma identidade própria comprometida com os aspectos sociais, preocupada com os problemas sanitários (alocação e priorização de recursos públicos), atenta à proteção e preservação do meio ambiente e alerta aos desdobramentos e implicações dos avanços científicos, essencialmente nas pesquisas com seres humanos $^{101}$.

Nesse sentido, os artigos da DUBDH trabalhados no curso de especialização da UnB tendo como base o CC situam o conhecimento da bioética dentro da realidade concreta, abrindo novas perspectivas - mais amplas no sentido biopsicosocial - para reflexão e ações da disciplina.

Assim, ao associar a bioética como campo normativo particular na atenção e cuidado da vida e da saúde, com os Direitos Humanos como campo normativo universal básico de obrigações morais e jurídicas para todas as formas de vida no planeta, identificam-se os valores fundamentais de uma ética universal pautada no respeito à dignidade humana, na luta pela igualdade de direitos, na liberdade, na justiça, fraternidade e paz ${ }^{102}$. 


\section{Qual o conteúdo adequado de um currículo de Bioética? Um currículo mínimo é possível?}

Com esta pergunta buscou-se analisar se o conteúdo abordado nos cursos era suficiente para capacitar profissionais ativos para questionar e argumentar na prática profissional.

Sobre este aspecto percebeu-se certa dificuldade nas respostas dos entrevistados, sem a certeza de um currículo mínimo necessário para um curso de especialização em bioética. Um entrevistado exemplificou a possibilidade de utilização de um currículo de bioética adequado à realidade latinoamericana.

"Elementos sobre origem e situação geral da Bioética mundial e no contexto latino-americano, com ênfase no Brasil; exigências básicas do método e atitudes de bioeticistas; fundamentos teóricos no discernimento (bio)ético; tópicos específicos em vista do direcionamento da especialização." (Coordenador F)

"Não possuo opinião; acredito que sim." (Coordenador E)

"Acredito que a Unesco foi muito feliz com a proposta do Core Curriculum: trata dos princípios da DUBDH, que não é focada em questões biomédicas, mas traz princípios que se referem a meio ambiente, a processos históricos de exclusão e violência, etc.(...) Se fosse pensar num currículo mínimo, eu sugeriria fortemente o Core Curriculum da Unesco." (Coordenador B)

Nesse sentido, com a finalidade de cumprir o artigo 23 da DUBDH, que trata do estímulo a programas de disseminação de informação e conhecimento em bioética, um grupo de pesquisadores vinculados a Unesco elaborou, em 2008, o Core Curriculum no intuito de apresentar os artigos da declaração para estudantes universitários ${ }^{103}$, sobretudo para aqueles residentes nos países em desenvolvimento ${ }^{104}$. O documento indicou a possibilidade do CC ser útil não somente para a formação pós-acadêmica, mas também para a educação continuada e para programas educacionais dirigidos a membros de comitês de ética ${ }^{103}$.

A abordagem metodológica do CC proporciona subsídios didáticos essenciais, como orientações gerais aos docentes, a indicação de carga horária mínima de estudo e o respectivo conteúdo programático para o adequado ensino de cada tema. É indicado para estudantes das áreas biomédicas e da saúde, e também para egressos de cursos das áreas 
humanas que tenham interface com a disciplina, como filosofia, direito, antropologia, sociologia.

A possibilidade de inovação e a flexibilidade de aplicação ao ensino em diferentes contextos são características essenciais do modelo curricular proposto. Desse modo, o CC não constitui uma proposta fechada, podendo inclusive ser utilizado como uma fonte complementar às demais abordagens de ensino em bioética.

\section{Quais os métodos de ensino-aprendizagem e de avaliação empregados na maioria das disciplinas do curso?}

Esta pergunta teve o intuito de verificar se havia alguma inovação no método tradicional de ensino-aprendizagem e no sistema de avaliação do estudante e se a interatividade era valorizada. As observações quanto aos modelos de ensino-aprendizagem e avaliação utilizados guardam similaridades em todos os coordenadores.

O que prevaleceu nas respostas foi a referência ao modelo tradicional de ensino com aulas expositivas, apresentação de seminários, abertura para o debate, fichamento de artigos, apresentação de monografia. Foi mencionado também o respeito à autonomia de cada docente responsável pela condução de módulo a ele solicitado. A ênfase das respostas dos entrevistados pode ser verificada nas assertivas abaixo:

"As disciplinas são ministradas através de aulas expositivas, seminários, debates, discussão de textos, estudos de casos, painéis e dinâmicas de grupo. Cada Unidade de Aprendizagem (disciplina) faz a avaliação do aluno através de fichamentos comentados de textos escolhidos, discussão de casos clínicos em grupo ou individualmente, apresentação de seminários do projeto de monografia e prova final. Há também atividades de casa como resenhas sobre textos ou livros ou fichamento. Todo aluno tem um orientador que o acompanha durante o curso com a finalidade de construir o projeto e a monografia." (Coordenador A)

"O curso segue uma lógica de aulas dialogadas com abertura para discussão. De modo geral, há uma exposição por parte do professor, com apresentação de um arcabouço teórico fundamental (que é acompanhado de leituras por parte dos cursistas). Em seguida é fomentado um debate aberto entre todos. Em alguns momentos são convidados especialistas de áreas mais técnicas e até mesmo organizações civis, (...), que trazem suas perspectivas para discussão. As avaliações são realizadas através de ensaios, resenhas, referatas e escrita de monografias e 
artigos, discussão de casos, simulação de comitês de ética, etc. Cada professor de um módulo faz suas escolhas." (Coordenador B)

"Diverso: cada disciplina pode usar metodologia específica. Aulas expositivas, uso de multimídia, filmes, trabalhos em grupo, estudo e debate de casos." (Coordenador D)

"Os professores tinham autonomia para métodos de ensino-aprendizagem e de avaliação. (...) Aulas expositivo dialogadas, estudo de caso, seminários, etc. Papers, prova, estudo de caso, seminário." (Coordenador E)

"Exposição com discussões e buscas complementares; alguns temas trabalhados em seminários e apresentação em classe; discussão de casos; avaliação de monografia de conclusão; discussão oral sobre conhecimentos pertinentes à monografia e outros conteúdos do curso." (Coordenador F)

"Aulas expositivas dialogadas; metodologias ativas de ensino; discussão de casos clínicos." (Coordenador G)

Finkler $^{37}$ considera um desafio pedagógico emergente o "ensinar Bioética", além de múltiplo, por exigir uma sensibilização para a importância da ética na formação, a busca por uma fundamentação teórica adequada a cada realidade social e cultural, e discussões sobre como desenvolver esse "ensino".

Correa $^{80}$, por sua vez, menciona três aspectos a serem considerados pelos docentes como desafios na formação em bioética: conhecer os alunos; promover a capacidade de diálogo e ações educativas para mudança de atitudes.

Primeiro, é importante que se tenha em conta a necessidade de superar atitudes negativas por parte dos alunos e até mesmo de profissionais incorporadas durante a graduação, tais como - a mentalidade cientificista; a priorização dos interesses econômicos; a atitude negativa ante a filosofia e a ética clínica aspectos notadamente diferentes na pós-graduação lato sensu e a passividade na formação acadêmica. Há que se levar em conta também os aspectos positivos como o crescente reconhecimento do sentido social da profissão; uma atitude crítica diante da mercantilização da medicina e uma curiosidade intelectual e atitude aberta de aprendizagem com a recuperação de antigos valores humanistas ${ }^{80}$.

Segundo, mudar atitudes e comportamentos de estudantes e profissionais é demasiado complexo, porém propõe como recurso metodológico satisfatório o exercício do diálogo, ou seja, a discussão de problemas morais por meio da escuta recíproca, da tolerância, da humildade, 
do respeito ao outro, livre dos dogmatismos científicos ou religiosos e das visões reducionistas ${ }^{80}$.

E por último, como ações educativas sugere tutorias em pequenos grupos de modo a facilitar a participação na prática ético-clínica, a aprendizagem baseada em problemas com amplo debate de modo a permitir que os alunos possam narrar seus casos e dilemas integrando a ética à prática clínica. O uso de recursos audiovisuais, filmes, reportagens veiculadas na imprensa pode ser considerado um meio útil para aproximar-se da realidade dos estudantes ${ }^{80}$.

Uma constatação importante é ressaltada quanto às aulas magistrais que, quando se trata de mudar atitudes e vivenciar valores, resultam menos eficazes que o trabalho em pequenos grupos. Considera-se que o desafio mais importante para um educador e professor de bioética é sensibilizar e influenciar o desenvolvimento moral de modo que o próprio aluno possa descobrir a importância que atribui a cada um de seus valores e incorporar esta reflexão em sua prática profissional ${ }^{80}$. Assim, defende a importância para a formação moral dos modelos de atuação como o melhor exemplo que pode ser transmitidos aos alunos, incentivando-os ao questionamento crítico e autônomo de seus próprios valores e atitudes ${ }^{80}$.

Gracia, citado por Finkler ${ }^{37}$, indica a necessidade de se trabalhar com grupos pequenos de forma mais prática que teórica, mais interativa e participativa, para que dessa forma o processo de ensino-aprendizagem seja capaz de influenciar o aperfeiçoamento do caráter moral e das atitudes. Enfatiza a valorização de períodos mais prolongados de análise com intenso deliberação de tudo que se é apresentado em detrimento da resolução de conflitos extremos e excepcionais.

Rego ${ }^{65}$ também defende a discussão em pequenos grupos com a participação ativa e a troca de experiências entre os alunos, como ocorre, por exemplo, na Aprendizagem Baseada em Problemas.

Dessa maneira, a formação em valores, como se pode depreender de um curso de bioética, não se deve restringir a um processo abstrato de transmissão de conteúdos na qual o estudante receba acriticamente a mensagem, mas que assuma uma posição ativa e atuante na incorporação das informações possibilitando a elaboração de seus próprios valores. Para isso, se 
torna fundamental o envolvimento acadêmico e o aspecto motivador do corpo docente como responsáveis e partícipes desse processo ${ }^{105}$.

Assim, a função docente deixa de ser a de um simples replicador de conteúdos por meio de aulas expositivas e magistrais para assumir a condição pedagógica de facilitador da aprendizagem ${ }^{106}$.

\section{O corpo docente possui formação acadêmica em bioética? Qual a formação acadêmica predominante do corpo docente?}

A pergunta procurou identificar a área de atuação dos professores e a carência ou não de bioeticistas no meio acadêmico.

De acordo com as respostas analisadas, percebe-se ainda a carência de uma formação bioética específica, no qual os entrevistados relatam o interesse próprio dos docentes como justificativa para a formação na área. Um dos entrevistados menciona que o curso conta com alunos egressos e também egressos de outros programas de pós-graduação em bioética. Também não houve predomínio de determinada área na composição do corpo docente. Alguns fragmentos de entrevista comprovam esta informação:

"Todos os membros do corpo docente têm iniciação em Bioética, mas não necessariamente por cursos acadêmicos de Bioética; considere-se que o curso começou quando a formação específica em Bioética era quase inexistente. De sua formação acadêmica profissional, mais frequentemente na área da saúde, aprofundam conhecimentos de Bioética para assumir as aulas. Vários docentes já pertencem à instituição, completando sua carga horária de atuação." (Coordenador F)

"Sim. Área da saúde. Porém, a carga horária foi igualmente distribuída entre professores das ciências humanas, sociais e sociais aplicadas e professores das ciências da vida e da saúde." (Coordenador E)

"Grande parte dos professores tem formação em Bioética. Pode-se dizer que um percentual considerável dos professores é egresso deste mesmo curso de especialização ou dos programas de pós-graduação." (Coordenador B)

Ao identificar-se como professor, é importante considerar não somente o que é ser professor, mas também o papel e as condições do exercício profissional. Desse modo, a importância de preparo e atualização tanto na área específica como no campo pedagógico apontam para uma prática educativa com o intuito de intervir na realidade social, caracterizando a profissão docente 
como prática social ${ }^{107}$ capaz de estimular o pensamento crítico, a educação para a autonomia e a emancipação ${ }^{25}$.

Um entrevistado respondeu sobre a iniciativa própria do docente como forma de capacitação em bioética:

"O corpo docente é constituído de professores que se interessaram por bioética e se desenvolveram por esforço próprio. A formação predominante é médica, direito, psicologia e enfermagem." (Coordenador C)

Pode-se afirmar que cabe ao professor a responsabilidade por sua própria formação continuada por meio de iniciativas individuais ou coletivas, pois o poder da formação pertence àquele que se forma a partir de sua própria trajetória individual, compartilhando espaços e experiências. É fundamental reconhecer-se como ser em permanente formação atrelado ao seu percurso de vida e suas vivências, na maneira singular de aprender e de perceber as circunstâncias na qual está inserido, como afeta e é afetado ${ }^{108}$.

O papel do docente, como formador de opinião, se reveste de fundamental importância neste processo. Exemplo de profissionalismo, habilidade didática, compreensão, engajamento e disponibilidade acadêmica são algumas das características a serem consideradas para os que se dedicam à arte de lecionar. $O$ professor deve representar um modelo ativo que propicie instrumentos para a deliberação ética consciente expondo sentimentos morais conflitantes e possibilitando uma reflexão crítica e racional ${ }^{79}$.

Nestas cinco últimas perguntas a área temática definida foi a formação profissional em bioética. Essa temática teve a finalidade de analisar a percepção dos coordenadores sobre a importância da bioética para a prática profissional e não simplesmente como exercício de reflexão abstrata.

\section{Qual o perfil dos alunos/profissionais que procuram o curso de especialização em Bioética?}

Esta pergunta pretendeu identificar qual era a área predominante e que tipo de carências eram mais relatadas pelos profissionais que buscavam os cursos. 
A maioria dos entrevistados relatou a área da saúde como a origem dos alunos/profissionais que procuravam os cursos, porém um dos coordenadores mencionou não ser a área da saúde a predominante e dois outros relataram não existir um predomínio específico de determinada carreira. Sobre essa questão, são importantes os seguintes trechos: (Coordenador E)

"O perfil prioritário foi de profissionais da saúde (psicologia, fisioterapia)."

"Pessoas sensibilizadas com questões humanitárias, especialmente na área de saúde e no atendimento a pessoas doentes; pessoas ligadas a grupos que desenvolvem ação comunitária de promoção social e/ou de atendimento institucional a doentes. Há também interesse em melhorar seu currículo profissional e mostrar mais habilitação para obtenção de emprego." (Coordenador F)

"Geralmente são profissionais da área de saúde, mas há muitos filósofos, sociólogos, assistentes sociais. Nos últimos anos não foi incomum receber profissionais relacionados aos órgãos de gestão pública..." (Coordenador B)

"Profissionais da área da saúde, Direito, Filosofia." (Coordenador G) (Coordenador C)

"A maioria é da área do direito. Em seguida médicos e psicólogos."

"Diverso: Não havia área dominante: nenhuma área reunia mais do que $20 \%$ do corpo discente." (Coordenador D)

"O corpo profissional é formado por filósofos, teólogos, médicos, cientistas sociais e sanitaristas e qualquer pessoa portadora de diploma de curso superior, em qualquer área, pode participar como aluno." (Coordenador A)

A bioética é tida como conhecimento aplicável a todas as profissões, especialmente às da área da saúde e, dessa forma, é atribuído fundamental importância à utilização de seus referenciais teóricos e práticos para uma atuação profissional consciente e crítica ${ }^{29}$.

Vidal ${ }^{109}$ ao descrever a distribuição dos alunos por profissões no programa de educação permanente em bioética da Redbioética da Unesco em 2010, encontrou o predomínio da área da saúde. Poucas profissões gozam do privilégio de poder compartilhar e mitigar a dor e o sofrimento humano como aquelas da área da saúde ${ }^{106}$. Embora os resultados encontrados constatem o forte predomínio desta área nos cursos de especialização em bioética, não se pode desprezar o interesse crescente das demais carreiras. 
Pode-se dizer que os profissionais que procuram estes cursos podem já estar 'sensibilizados' pela inquietude bioética. Percebe-se, ainda que de maneira intuitiva, a insuficiência da formação profissional para abordar com eficácia os conflitos éticos na prática profissional cotidiana ${ }^{110}$.

\section{Como a Bioética pode contribuir para a aproximação entre teoria e prática para os estudantes do curso analisado?}

Com essa pergunta buscava-se identificar nos entrevistados se existiam esforços para uma abordagem prática da bioética com a devida sustentação conceitual/epistemológica, se havia uma abordagem quanto aos dilemas éticos da prática clínica.

Praticamente todos os entrevistados relataram o fato de ser a bioética ética aplicada, útil na solução dos diferentes conflitos pelos quais passam os profissionais na prática clínica cotidiana. Vale destacar os seguintes trechos das entrevistas:

"Despertando o interesse e fazendo com que os estudantes de bioética introduzam temas de bioética na sua vida profissional e nos seus locais de trabalho." (Coordenador C)

"A Bioética oferece as dimensões éticas da e na ação; representa um aprofundamento ou mesmo uma iniciação à ética nas diferentes áreas a que o estudante se dedica, especialmente em contextos em que os aspectos éticos se reduzem a deontologias formais. Uma pedagogia da Bioética para isso exige mostrar leituras de seus fundamentos e critérios em situações de algum modo experimentadas pelos estudantes." (Coordenador F)

"A bioética trata, essencialmente, de problemas práticos, isto é, daqueles decorrentes das atividades no campo da saúde ou em áreas correlatas, como a ambiental e a social, o que significa que os cursistas terão contato com questões cotidianas. E $O$ instrumental teórico que fornecemos no curso permite esta aproximação. A análise de situações concretas, sob o prisma de diferentes correntes da bioética, é um exercício constante para os cursistas." (Coordenador B)

"Na capacitação para reflexão e tomadas de decisão em conflitos éticos envolvendo sua profissão." (Coordenador E)

"Capacitação para exercício profissional em Comitês de Bioética Hospitalar; treinamento de componentes de Comitês de Ética em Pesquisa; melhora na atuação clínica de profissionais de saúde em relação aos conflitos éticos e morais." (Coordenador A) 
Se a disciplina bioética já surge como proposta nos cursos de graduação, os profissionais deveriam ter a possibilidade de especializar-se nela, assim como acontece nas demais disciplinas cursadas na graduação. Com o advento dos comitês de bioética hospitalar, comitês de ética em pesquisa, os profissionais se deparam com situações nas quais não estão capacitados para atuar. São conhecimentos que não demandam teorização e investigação estrita, como propõe os mestrados e doutorados, mas que requerem uma aplicabilidade prática ${ }^{110}$.

Nesse sentido, Lenoir ${ }^{53}$ sugere que o ensino da bioética seja revestido de um caráter prático (estudo de caso, diálogo com pesquisadores e técnicos) e não se limite apenas à reflexão geral de princípios. O curso de especialização em bioética da UnB se aproxima dessa abordagem quando, por exemplo, no módulo "Bioética Clínica e Ética em Pesquisa", ocorre a simulação de um CEP, no qual os alunos, divididos em grupos, são instados a relatar e dar parecer em um projeto de pesquisa e apresentá-lo ao restante da turma com posterior abertura para debate e considerações, assemelhando-se muito da realidade vivenciada por um CEP ${ }^{84}$.

$\mathrm{Na}$ formação em bioética se torna prioritário aprimorar e transformar atitudes e comportamentos por meio da capacidade de diálogo e deliberação moral diante dos problemas e decisões ético-clínicas ${ }^{80}$. Deve-se buscar a formação de profissionais competentes dotados de conduta ética, comprometidos com a cidadania e capazes de pautar sua atuação com responsabilidade social e visão humanística ${ }^{25}$.

Amorim ${ }^{111}$ afirma ser urgente uma educação para o cuidado, em todos os níveis, áreas e disciplinas, capaz de orientar o ser humano a melhorar-se moralmente, na qual valores como a solidariedade, a bondade, a generosidade e a compaixão sejam fomentadas com possível repercussão e transformação do meio externo e consequente contribuição para um mundo melhor.

Gomes e cols. ${ }^{84}$ relataram que o processo de ensino-aprendizagem fez com que os alunos incorporassem os conhecimentos adquiridos no curso de especialização da UnB, tanto na vida profissional quanto pessoal. Conceitos como tolerância, pluralismo, vulnerabilidade, autonomia passaram a fazer parte da vida cotidiana, levando a reflexão ética para as diversas dimensões da vida social: no ambiente familiar, nas relações interpessoais, na atuação 
profissional. Infere-se que parte dessa incorporação pode ser atribuída à possibilidade de aplicação do conhecimento apreendido, ou seja, a bioética compreendida como ética prática, que se materializa na ação cotidiana, amparada por parâmetros éticos na dimensão social ${ }^{84}$.

Enquanto a bioética não for incorporada ao discurso cotidiano, crítico e contestador, será considerada como um "saber invisibilizado", uma "fala inaudível", refém de formulações deslocadas, prisioneira de posições normativas e prescritivas, limitada a espaços fechados distantes de seu potencial questionador e transformador ${ }^{25}$.

\section{Como você avalia a necessidade e importância de um curso de especialização em bioética na formação profissional?}

Esta pergunta teve a finalidade de identificar o que os coordenadores pensam que os profissionais que procuravam formação em bioética esperavam alcançar com o curso.

Praticamente todos os entrevistados relataram a relevância do curso para uma atuação profissional mais ética, humanística e interdisciplinar que ainda necessita ser complementada, no entanto não exclusivamente pela bioética. Os coordenadores resumiram sua percepção sobre este questionamento da seguinte forma:

"Diante da carência da educação para a ética nos cursos brasileiros, a especialização em Bioética é certamente um grande ganho. Mas isto não quer dizer que seja necessária para todo profissional, uma vez que a educação ética indispensável pode ser suprida também por outras modalidades de formação." (Coordenador F)

"Há muitas motivações, mas predomina a formação ética e interdisciplinar dos profissionais." (Coordenador D)

"Desnecessário (se entendermos "necessidade" a partir da racionalidade instrumental). Importante o é, no sentido de "relevante". Tem importância na formação humanística do profissional." (Coordenador E)

"O curso de especialização é interdisciplinar, tanto no que diz respeito aos docentes como aos discentes. (...) Todas as discussões e conteúdos do curso são voltados para esta característica, que objetiva ampliar a visão de mundo, diminuir os preconceitos contra as pessoas que portam diferentes crenças e valores. O objetivo do curso tem sido atingido, pois ao seu término, as opiniões mudaram e há um maior respeito às diferenças e, portanto, uma melhor avaliação no sentido de analisar e 
prescrever julgamentos de ordem ética. Isto se reflete nos trabalhos apresentados durante o curso e nas monografias." (Coordenador A)

"Grande parte das pessoas que procuram o curso vem buscar respostas para desafios concretos da vida profissional. O curso de especialização é quase um espaço para manifestação e análise das indignações contra as mazelas sociais e dilemas profissionais, sem perder de vista que as discussões precisam se assentar em bases teóricas para poder fazer sentido à luz da bioética. (...) De maneira geral, os cursistas buscam complementar a formação humanística que não receberam adequadamente durante suas graduações. Um curso que permita um espaço de construção deste tipo de conhecimento gera, além de satisfação pessoal, uma mudança de postura profissional. Os automatismos tecnicistas ganham um arcabouço crítico humanístico. O médico repensa sua forma de tratar o paciente, o biólogo repensa suas intervenções nos genes, um enfermeiro revisita a maneira de cuidar e por aí vai. (...) Posso concluir que, independente da profissão, os cursos de bioética, se bem estruturados, podem ser um espaço muito interessante de interlocução e de formação humanística." (Coordenador B)

O ensino da bioética, como ética aplicada, permite o desenvolvimento da análise ética no contexto das práticas de saúde e no pluralismo moral presente na sociedade, assegurando a tomada de decisões que respeitem a dimensão biopsicossocial do ser humano, transcendendo a linearidade deontológica e legal, importante, porém insuficiente, dos códigos de ética profissional $^{112}$. A bioética avalia as intervenções humanas segundo valores morais fundamentados na dignidade humana e nos direitos fundamentais da pessoa ao se posicionar frente ao questionamento Se é tecnicamente possível é eticamente aceitável? ${ }^{101}$

Assim, é dever dos profissionais de saúde, diante de qualquer conflito moral, identificar os problemas éticos existentes e sugerir soluções práticas que melhor atendam os interesses do paciente, tendo o arcabouço bioético como referência ${ }^{106}$.

Desse modo, deve-se buscar a formação de profissionais eticamente competentes dotados de postura ética, comprometidos com a cidadania e capazes de pautar sua atuação com responsabilidade social e visão humanística $^{112}$. Para Serodio e Almeida ${ }^{79}$ a formação ética dos profissionais de saúde passa pela inserção da bioética nos mais distintos espaços, desde a graduação até a pós-graduação. 


\section{Qual o domínio de conhecimento mínimo que o profissional necessita para se tornar um bioeticista?}

Buscou-se identificar quais os conteúdos eram considerados mais importantes e quais não poderiam deixar de ser abordados em um curso de especialização.

Interessante ressaltar as divergências relatadas pelos entrevistados quanto ao uso do termo bioeticista, entretanto, um dos entrevistados mencionou a aproximação entre as culturas humanas e científicas como possibilidade de conteúdo mínimo necessário a um curso de especialização.

"Bioeticista é um termo genérico que se abre a vários graus de especificidade e qualidade; uma exigência básica começa por uma noção sobre possíveis fatores que interferem ou influenciam a dimensão ética em sua área de atuação; e ter alguma clareza de razões ou fundamentos que amparem seu discernimento, atitudes e propostas bioéticas." (Coordenador F)

"Não compreendemos que seja possível usar o termo 'bioeticista'. Sempre incentivamos que os estudiosos e pesquisadores em bioética se compreendam como profissionais de suas áreas que se aproximam da Bioética e se mantem em diálogo." (Coordenador D)

"Discordo, do ponto de vista epistemológico, da existência de uma categoria profissional denominada 'bioeticista"'. (Coordenador E)

"Acho que a fórmula básica foi estabelecida por Potter: (...) a reaproximação entre a cultura humanística e a cultura científica. Isso significa que um bioeticista que venha de uma área hard, precisa se aproximar dos conhecimentos das áreas soft e vice-versa. $\mathrm{Na}$ prática, um bioeticista deve transitar entre aspectos filosóficos, sociológicos e antropológicos do conhecimento biomédico, por exemplo." (Coordenador B)

É oportuno ressaltar o espaço social que a bioética vem conquistando nos últimos anos, haja vista o crescente número de bioeticistas prestando aconselhamento a legisladores e gestores na elaboração de políticas públicas. Nessa perspectiva, é imprescindível a ampliação da discussão temática para além dos aspectos clínicos, individualizada, para uma reflexão relacionada com o campo da saúde púbica, dirigida às particularidades associadas à saúde das coletividades de modo a compreender os princípios e valores éticos envolvidos nas tomadas de decisões no campo da saúde ${ }^{113}$. 
Hossne e cols. ${ }^{96}$ questionam sobre quem se apresenta com credenciais para o papel de bioeticista e quem somente estaria se aventurando em explorar os espaços de imagem que ali se abrem. É essencial, portanto, cuidado com a qualidade das intervenções para que a bioética ganhe consistência e respeitabilidade, e não caia em descrédito diante do fascínio midiático despertado por ela.

Para tanto, é fundamental que o ensino da bioética se dê nos mais diferenciados e múltiplos espaços - graduação, pós-graduação lato sensu e stricto sensu - valendo-se dos distintos modelos de análise bioética referendados pela literatura, ou seja, que não fique restrito à utilização de um único modelo de análise, como o principialismo, por exemplo ${ }^{113}$.

Nesse sentido, a bioética, como disciplina, tem despontado nas estruturas convencionais da educação brasileira conquistando progressivamente espaço junto às universidades e instituições, nas mais distintas áreas e carreiras profissionais contribuindo para a mediação, o diálogo e a tolerância no debate dos problemas éticos vivenciados atualmente ${ }^{29}$.

10. Qual a sua análise sobre os cursos de especialização em Bioética possuírem um "selo" de certificação de qualidade obtido junto a uma entidade científica (tipo Sociedade Brasileira de Bioética - SBB) ou pela própria Capes/MEC?

Pretendeu-se com esta pergunta verificar o entendimento dos entrevistados e a viabilidade de se propor critérios de qualidade a serem adotados em cursos de bioética.

De acordo com as respostas, percebeu-se contradição entre o entusiasmo e a dificuldade de implementação da proposta de uma certificação de qualidade para os cursos de especialização em bioética.

"Diretrizes curriculares boas ajudam para alertar e orientar sobre pontos relevantes de uma área de conhecimento, e isto me parece servir também para os cursos de especialização; isto supõe a boa qualidade das diretrizes para subsidiar sem inibir a especificidade do curso. Um selo de certificação de uma entidade é um indicativo sobre a qualidade; acho que seria um bom serviço se a SBB conseguisse chegar a um padrão para oferecer a programas que se interessassem; mas este serviço tem custos, inclusive de manutenção e não é fácil." (Coordenador F) 
"Considero isto muito complicado. Vai depender do modo como isto venha a ser construído." (Coordenador D)

"Acredito que um curso de especialização acadêmica deve atender às exigências do MEC, Resolução do Conselho Nacional de Educação n.1 de 08/06/2007." (Coordenador E)

"Penso que representaria um grande avanço de qualidade. Também representaria a possibilidade de definir um currículo mínimo para esta área de conhecimento." (Coordenador C)

"Uma acreditação dos cursos seria bem-vinda! Principalmente para evitar que nossos pesquisadores e profissionais sejam assediados por iniciativas educacionais escusas. O campo de conflitos no qual a bioética se insere é um "prato cheio" para iniciativas de "treinamento ético", isto é, de cursos que visem muito mais enquadrar profissionais, principalmente os da área da saúde, nos esquemas regulatórios internacionais que favoreçam, por exemplo, o uso de duplo standard em pesquisa clínica ou a flexibilização de alguns princípios éticos para atender iniciativas de mercado. Tenho convicção que uma chancela pública reduziria este tipo de iniciativa. Não se pode permitir que pesquisadores vinculados à Big Pharma venham treinar nossos pesquisadores sobre como devem ser conduzidos os estudos com a população brasileira a fim de atender interesses comerciais. Este talvez seja o conflito de interesses mais sério que assola as iniciativas educacionais no Brasil. Se a SBB assumir de modo sério e transparente esta iniciativa, seria muito interessante." (Coordenador B)

\subsection{Análise de uma proposta de conteúdo mínimo para os cursos de pós- graduação lato sensu em bioética no Brasil}

O processo de certificação pedagógica pode ser considerado um instrumento de avaliação e reconhecimento formal de que os cursos de especialização em bioética certificados atendem a requisitos previamente estabelecidos e que a instituição de ensino mantenedora demonstra capacidade e competência acadêmica para a oferta dos mesmos.

Tem por finalidade contribuir para o desenvolvimento de uma cultura de qualidade do ensino em bioética por meio de uma estratégia eficaz que garanta uma melhoria sólida e contínua. Consiste na verificação externa de determinado curso com o intuito de conferir um "selo" de qualidade e reconhecimento social.

A proposta pode ser considerada um avanço, mas ao mesmo tempo é complexa e ousada, pois da forma como será conferida a certificação poderá ocorrer uma duplicidade de avaliação haja vista as resoluções do Conselho Nacional de Educação que regulamentam a oferta de cursos de especialização 
no Brasil. Nesse sentido, nada mais justo do que uma entidade com reconhecimento nacional na área, como a Sociedade Brasileira de Bioética, ser responsabilizada pelo Ministério de Educação, via Capes, para conduzir esse processo, definindo os parâmetros necessários e se responsabilizando pela formação e capacitação de experts em certificação pedagógica.

A função dessa entidade seria a de avaliar o projeto pedagógico de cursos oferecidos por determinadas instituições de ensino de acordo com os parâmetros estabelecidos. Requer a constituição de comitês específicos formados por membros devidamente capacitados com finalidade de realizar a certificação tanto dos cursos existentes como dos que serão futuramente ofertados.

É oportuno ressaltar que a certificação aqui proposta não visa conferir legalidade aos certificados de conclusão dos cursos de especialização, sendo esta uma prerrogativa de determinadas instâncias específicas do Ministério da Educação. É necessário também que se respeitem as características de diversidade entre os cursos e a singularidade de cada curso.

Como proposta de certificação, alguns requisitos merecem ser observados, dentre outros que porventura possam ser acrescidos, como:

- os cursos de especialização em bioética devem ser oferecidos por instituições de ensino reconhecidas e credenciadas junto ao Ministério da Educação conforme resolução específica, preferivelmente faculdades, centros universitários ou universidades;

- demais instituições que desejem oferecer cursos de especialização devem apresentar competência documentada na área de bioética, tais como publicações científicas e dissertações de mestrado e teses de doutorado;

- a filosofia e os objetivos dos cursos devem estar claramente definidos e expostos, consistentes com a prática da bioética;

- o corpo docente deverá ter comprovada formação e/ou reconhecimento acadêmico em bioética;

- deve ser considerada a adequação da formação do docente à disciplina específica que ministra;

- os cursos deverão fazer uso de métodos apropriados ao ensino em bioética com vistas a atender os diferentes formatos de aprendizagem dos 
alunos, com criatividade e inovação, para a efetivação dos objetivos delimitados;

- o pré-requisito para admissão no curso não deve ser restrito a uma determinada área profissional exclusivamente, garantindo a igualdade de oportunidade de acesso e o respeito à pluralidade peculiar da bioética;

- os cursos devem estimular um ambiente de aprendizagem interdisciplinar capaz de proporcionar oportunidades de conhecimentos a partir de múltiplas formas de pensamento, distintos conceitos sociais, respeito ao pluralismo moral, à interculturalidade, aos valores e comportamentos éticos, estimulando a troca de experiências interpares;

- especial atenção deve ser dada às teorias/correntes de pensamento bioético desenvolvidas no Brasil e no mundo sem, contudo deixar de lado os fundamentos de ética e de bioética;

- o projeto pedagógico deve ser previsto com o objetivo de assegurar a construção progressiva de conhecimentos e habilidades de pensamento com a consequente capacidade de análise ética frente a tomada de decisões;

- o conteúdo abordado deverá possibilitar não só crescimento profissional, mas também pessoal capaz de nutrir um compromisso de aprendizagem de forma contínua, individual e/ou independente;

- o projeto pedagógico deve ser regularmente revisto pela coordenação do curso podendo receber contribuições de docentes ad hoc e de representantes dos estudantes;

- a organização interna do curso deverá contar com uma secretaria regularmente acessível, representação discente, a disponibilização de material didático por meio impresso e/ou on line, as normas para a realização do trabalho de conclusão do curso com incentivo e previsão de publicação do trabalho final na forma de artigo científico;

- comprovação da existência de biblioteca com acervo atualizado, condições de pesquisa e acesso à informação tanto para docentes como para discentes.

O Conselho Nacional de Educação por meio da Câmara de Educação Superior regularmente edita pareceres e resoluções que tratam de normatizar a oferta de cursos de especialização no país. Recentemente foi editada a 
Resolução oㅡ 2 de 12 de fevereiro de 2014 (Anexo 5), que institui a criação de cadastro nacional de oferta de cursos de pós-graduação lato sensu das instituições credenciadas no Sistema Federal de Ensino. Trata-se de ferramenta disponibilizada pelo Ministério da Educação com informações de cada curso oferecido a partir do ano de 2012.

Devida à complexidade da implementação de uma proposta de certificação, já anteriormente mencionada, uma proposta de conteúdo mínimo a ser trabalhado nos cursos de especialização em bioética que contemple as especificidades e o contexto brasileiro é apresentada a seguir.

\subsubsection{Da proposta de currículo mínimo - a aplicabilidade prática do Core Curriculum da Unesco: uma realidade possível}

A forte proximidade histórica da bioética com a deontologia ou ética profissional nos currículos de estudo das profissões de saúde, aliada à diversidade de temas éticos persistentes e emergentes a serem trabalhados, acabaram originando grande variedade de abordagens didáticas as quais, apesar de despertar pouco interesse entre os estudantes, dificultam aos docentes a escolha e organização de conteúdos para o adequado ensino da disciplina. Torna-se pertinente, portanto, a busca de novas alternativas às abordagens tradicionais para o ensino da bioética, mais participativas, dinâmicas e atrativas ao olhar discente.

É a partir deste panorama que pesquisadores vinculados aos programas educativos de ética da Unesco organizaram um Core Curriculum (CC) para o ensino da bioética. Nesse documento, que tem como base de conteúdo os 15 princípios constantes da Declaração Universal sobre Bioética e Direitos Humano $^{103}$, são apresentados elementos teóricos, indicações de material instrucional e casos complexos com questões para discussão que tem por finalidade facilitar a organização da prática docente, possibilitando melhor compreensão dos estudantes acerca de situações conflitivas tratadas no âmbito da bioética.

A estrutura do programa tem carga horária aproximada de 60 horas e é composto por 17 unidades temáticas. As unidades temáticas 1 e 2 proporcionam uma aproximação geral à ética e da bioética e são seguidas por 
mais 15 unidades sequenciais que abordam e discutem os 15 artigos da DUBDH.

A proposta da Unesco sugere que algumas das unidades podem ser ministradas conjuntamente, mas cada uma delas desenvolve um tema específico. Pode-se destacar que cada unidade apresenta elementos teóricos fundamentais para a compreensão do tema, bem como exemplos atuais e relevantes que podem ser adequados à diversidade de contextos culturais relacionados com a realidade onde estão sendo apresentados.

São três os objetivos gerais de aprendizagem proposta pelo CC: (1) capacitar os estudantes para identificar questões éticas das práticas biomédicas; (2) fornecer elementos teóricos para que os estudantes apresentem justificativas racionais para a tomada de decisão ética; e (3) capacitar os estudantes na aplicação dos princípios da DUBDH.

De acordo com a Unesco, a utilização do CC em sala de aula assim como em qualquer curso universitário, deve dispor de estratégias de avaliação. A proposta envolve a avaliação dos estudantes (exames orais, ensaios, análises de casos, provas com questões de múltipla escolha, trabalhos e testes escritos) e do próprio CC. Por meio de um questionário padronizado que acompanha a proposta, estudantes e professores podem avaliar o método utilizado, com o objetivo de dar retorno à Unesco e contribuir para a sua melhoria $^{104}$.

Mais recentemente, o grupo de pesquisadores responsável pela elaboração do CC construiu materiais complementares, como um manual para o instrutor, bem como casebooks para auxiliar a discussão de algumas unidade $^{104,114,115,116}$. O manual para o instrutor detalha cada unidade, reforça objetivos centrais de aprendizagem e orienta quanto aos materiais complementares. Sugere também estratégias para maximizar a participação dos estudantes, como, por exemplo, em que momentos do desenvolvimento da proposta deverão ser organizados grupos específicos de discussão ou ser utilizado um determinado documentário.

A Cátedra Unesco de Bioética da UnB, desde 2010, tem adotado o Core Curriculum como instrumento didático para o desenvolvimento da disciplina "Introdução à Bioética", ofertada todos os semestres pela Faculdade de Ciências da Saúde da UnB desde 1994, bem como tem fundamentado todo 
seu programa stricto sensu (mestrado e doutorado) nesta perspectiva. Durante este período, embora a disciplina seja direcionada preferencialmente aos estudantes das áreas biomédicas e da saúde, atendeu também a estudantes de outras áreas de conhecimento, especialmente das ciências sociais e humanas.

Assim, seguindo a proposta original da Unesco, foram incorporados os artigos da DUBDH às discussões das situações persistentes e emergentes em bioética, adequando os conteúdos do CC à realidade brasileira. A Cátedra Unesco de Bioética da UnB, então, passou a propor como meta principal contribuir para o aprimoramento de estratégias de ensino da bioética entre os estudantes partindo da compreensão de que o Core Curriculum não é "um curso completo, mas fonte de inspiração ${ }^{103}$ e de que seu uso deve ser contextualizado às idiossincrasias culturais, morais e sociais de cada cultura, grupo social ou região que o adota.

A Declaração da Unesco é um documento "não vinculante", ou seja, não tem poder de lei. Contudo, sua proposta é instrumentalizar seus seguidores para proporcionar, nas decisões a serem tomadas ou nas práticas a serem desenvolvidas, uma orientação teórica e prática para a elaboração de legislações nacionais e regulamentações profissionais ${ }^{117}$.

De acordo com Saada ${ }^{118}$, os avanços técnico-científicos que caracterizam o mundo atual têm um impacto sobre a conduta humana, individual e coletiva, sobre as relações interpessoais e os valores morais e éticos que regem e regulam a vida social. Nesse sentido, o conjunto dos artigos da DUBDH contempla um rol de condições capacitadas a reduzir tal impacto, respondendo objetivamente às demandas por soluções éticas para os problemas atualmente vivenciados no contexto internacional.

Arduamente construída e duramente conquistada após quase três anos de intensas discussões realizadas pelos cinco continentes, o conteúdo da Declaração Universal sobre Bioética e Direitos Humanos da Unesco consolida avanços concretos para o estabelecimento de um novo referencial epistemológico e uma nova agenda temática para a Bioética do século $\mathrm{XXI}^{119}$. Uma bioética mais humana, mais palpável e mais próxima dos verdadeiros conflitos persistentes que assolam a maioria dos países periféricos do planeta $^{120}$. 
Nesse sentido, a utilização pedagógica do Core Curriculum pode ser um instrumento de grande utilidade, contribuindo e influenciando na formação ética e na formação em bioética de estudantes nas diferentes situações e problemas relacionados com estes indispensáveis campos do conhecimento acadêmico $^{121}$. 


\section{CONSIDERAÇÕES FINAIS}

De acordo com o presente estudo, observaram-se algumas características semelhantes que permitem inferir uma preocupação em proporcionar cursos de boa qualidade, seja por meio da credibilidade acadêmica das instituições e de seus corpos docentes, como também pela diversidade de enfoques trabalhados.

Percebe-se que os cursos têm em comum o objetivo de uma visão básica e integradora da bioética com o intuito de despertar o interesse dos profissionais para a reflexão e o debate dos problemas bioéticos, sejam eles filosóficos, científicos, jurídicos, sanitários, ambientais ou econômicos.

Estruturados em metodologia interdisciplinar, os cursos têm como particularidade o respeito à pluralidade, característica essencial da bioética. Priorizam o caráter participativo e interativo dos alunos, associando à análise teórica a capacitação tanto para a discussão como para a tomada de decisão frente aos problemas e conflitos existentes nas diferentes áreas do conhecimento.

Segundo Segre ${ }^{122}$, é a reflexão a respeito de situações pensadas e sentidas por pessoas com crenças e experiências diferentes, que a partir do confronto de ideias, possibilitará encontrar um consenso. Assim, o ensino da bioética reforça sua inerente natureza interdisciplinar, ressaltando que não só os cursos voltados à área da saúde necessitam oferecer reflexões desse tipo não se restringindo simplesmente à transmissão cognitiva ${ }^{70}$.

Dessa forma, os cursos parecem preencher uma carência ética deixada pela graduação e suprir as expectativas de quem procura conhecimento para enfrentar, na prática, os conflitos éticos, além de possibilitar uma permanente auto-avaliação no que diz respeito à atuação profissional.

Além das bases filosóficas e dos fundamentos da bioética comuns aos cursos, identificou-se nos diversos programas diferentes perspectivas e enfoques, o que pode ser atribuído ao perfil acadêmico do corpo docente ou do coordenador responsável pela condução do curso.

É oportuno destacar que o curso de especialização em bioética da Universidade de Brasília, diferentemente dos demais cursos analisados, tem como característica principal trabalhar uma bioética crítica, politizada e 
socialmente engajada em oposição a uma bioética meramente descritiva e neutral. É importante que novos caminhos sejam trilhados, mais amplos e comprometidos, capazes de enfrentar os macroproblemas bioéticos com os quais se deparam cotidianamente as nações periféricas do mundo, sobretudo da América Latina e do Caribe.

Ao adotar e incorporar os princípios da DUBDH como referencial teórico por meio da prescrição contida no Core Curriculum, o curso de especialização oferecido pela Cátedra Unesco de Bioética da UnB não se restringe a analisar somente as questões sanitárias e educacionais, a interpretar as questões epidemiológicas e ambientais, mas propor e desenvolver mecanismos de intervenção capazes de definir novas frentes de pesquisa no campo biotecnocientífico, na formação de pessoal e no papel do Estado na proteção de seus cidadãos, principalmente os mais vulneráveis.

Nesse contexto e sob esta ótica, o ensino da bioética tem sido um dos maiores desafios da atual fase de ampliação conceitual do campo. Deve abandonar o modelo tradicional, no qual o conhecimento está centralizado no professor, o que faz com que os alunos nem sempre sejam estimulados a refletir $^{70}$.

Novas estratégias e metodologias de ensino devem ser validadas em contextos diferenciados, a fim de aprimorar sua estrutura e melhorar sua eficácia. Modificar modelos tradicionais e deficitários de ensino é uma tarefa que exige dos que se dedicam ao magistério flexibilidade e criatividade, uma abertura ao novo.

O fortalecimento dos espaços para a discussão de temas bioéticos, aliado à construção de sólida formação teórica-crítica de estudantes, deve constituir uma prerrogativa indispensável principalmente nos países nos quais existem marcantes desigualdades e iniquidades sociais, como é o caso do Brasil.

A contextualização e o aperfeiçoamento das estratégias propostas pelo Core Curriculum, fundamentada na Declaração Universal sobre Bioética e Direitos Humanos da Unesco, é uma importante alternativa para docentes que buscam organizar suas práticas didático-pedagógicas em bioética, com 0 propósito de proporcionar melhores resultados à formação dos seus estudantes. 
Para finalizar, sendo o Brasil um dos signatários da Declaração Universal sobre Bioética e Direitos Humanos da Unesco, por meio de sua operacionalização pedagógica no campo educacional representada pela aplicação do seu Core Curriculum, parece ser este o instrumento mais adequado à efetivação de uma base para conteúdo mínimo a ser exigido pelo Ministério de Educação para acreditação futura dos cursos de pós graduação lato sensu em bioética no país sob a supervisão da Sociedade Brasileira de Bioética, com o respaldo oficial do Ministério de Educação via Capes. 


\section{REFERÊNCIAS}

1. Matos MS, Tenório R. Percepção de alunos, professores e usuários acerca da dimensão ética na formação de graduandos de odontologia. Ciência \& Saude Coletiva 2010; 15(supl. 2): 3255-64.

2. Silva RP, Ribeiro VMB. Inovação curricular nos cursos de graduação em medicina: o ensino da bioética como uma possibilidade. Rev Bras Educ Med 2009; 33(1): 134-43.

3. Cezar PHN, Gomes AP, Siqueira-Batista R. O cinema e a educação bioética no curso graduação em medicina. Rev Bras Educ Med 2011; 35(1): 93-101.

4. Dantas $\mathrm{AA}$, Martins $\mathrm{CH}$, Militão MSR. O cinema como instrumento didático para a abordagem de problemas bioéticos: uma reflexão sobre a eutanásia. Rev Bras Educ Med 2011; 35(1): 69-76.

5. Caramico HJ, Zaher VL, Rosito MMB. Ensino da bioética nas faculdades de medicina do Brasil. Bioethikos 2007; 1(1): 76-90.

6. Pires J, Garrafa V. Educação: nova fronteira da bioética. Ciência \& Saude Coletiva 2011; 16(supl. 1): 735-45.

7. Mascarenhas NB, Santa-Rosa DO. Ensino da bioética na formação do enfermeiro: interface com a bibliografia adotada. Acta Paul Enferm 2010; 23(3): 392-8.

8. Pessalacia JDR, Oliveira VC, Rennó HMS, Guimarães EAA. Perspectivas do ensino de bioética na graduação em enfermagem. Rev Bras Enferm 2011; 64(2): 393-8.

9. Finkler M, Verdi MIM, Caetano JC, Ramos FRS. Formação profissional ética: um compromisso a partir das diretrizes curriculares? Trab Educ Saude 2011; 8(3): 449-62.

10. Dantas F, Sousa EG. Ensino da deontologia, ética médica e bioética nas escolas médicas brasileiras: uma revisão sistemática. Rev Bras Educ Med 2008; 32(4): 507-17.

11. Ferrer J, Álvarez JC. Para fundamentar a bioética - teorias e paradigmas teóricos na Bioética contemporânea. São Paulo: Edições Loyola, 2005.

12. Mascarenhas NB, Santa-Rosa DO. Bioética e formação do enfermeiro: uma interface necessária. Texto Contexto Enferm 2010; 19(2): 366-71.

13. Siqueira JE. Educação em bioética no curso de medicina. O Mundo da Saude 2005; 29(3): 402-10. 
14. Aires CP, Hugo FN, Rosalen PL, Marcondes FK. Teaching of bioethics in dental graduate programs in Brazil. Braz Oral Res 2006; 20(4): 285-9.

15. Cohen C. Como ensinar a bioética. O Mundo da Saude 2005; 29(3): 43843.

16. Monteiro PJC. O ensino da ética/bioética nos cursos de graduação em Enfermagem, Medicina e Odontologia na cidade de Manaus. São Paulo. [Dissertação] Mestrado em ensino em ciências da saúde. Universidade Federal de São Paulo, 2005, 145 p.

17. Musse JO, Boing AF, Martino FS, Silva RH, Vacarezza GF, Ramos DLP. O ensino da bioética nos cursos de graduação em odontologia do estado de São Paulo. Arq Cienc Saude 2007; 13(1): 13-16.

18. Finkler $M$, Caetano JC, Ramos FRS. A dimensão ética da formação profissional em saúde: estudo de caso com cursos de graduação em odontologia. Ciência \& Saude Coletiva 2011; 16(11): 4481-92.

19. Brasil. Conselho Nacional de Educação. Câmara de Educação Superior. Resolução no 1/2007, de 8 de junho de 2007. Diário Oficial da União, Seção 1, pág. 9.

20. Flexner A. Medical education in the United States and Canada: a report to the Carnegie Foundation for the Advancement of Teaching. New York: Carnegie Foundation for the Advancement of Teaching; 1910.

21. Rego S, Palácios M, Schramm FR. Ensino da bioética nos cursos de graduação em saúde. In: Marins JJN, Rego S, Lampert JB, Araujo JGC. Educação médica em transformação. São Paulo: Hucitec; 2004. p.165-85.

22. Kottow M. Cambios de actitudes éticas a lo largo de los estúdios de medicina. Rev Méd de Chile 1993; (121):379-84.

23. Pyrrho M, Prado MM, Cordón J, Garrafa V. Análise bioética do Código de Ética Odontológica brasileiro. Ciência \& Saude Coletiva 2009; 14(5): 1911-8.

24. Amorim KPC. Nos labirintos da vida: a (bio)ética na formação de odontólogos (a visão de docentes). [dissertação]. Natal: Centro de Ciências Sociais da Saude, UFRN; 2002.

25. Ramos FRS. O discurso da bioética na formação do sujeito trabalhador da saúde. Rev Trab, Educação e Saúde 2007; 5(1): 51-77.

26. Schuh $\mathrm{CM}$, Albuquerque IM. A ética na formação dos profissionais da saúde: algumas reflexões. Rev Bioét 2009; 17(1): 55-60. 
27. Oliveira AAS, Villapouca KC, Barroso W. Perspectivas epistemológicas da bioética brasileira a partir da teoria de Thomas Khun. Rev Bras Bioética 2005; 1(4): 363-85.

28. Siqueira JE, Sakai MH, Eisele RL. O ensino da ética no curso de medicina: experiência da Universidade Estadual de Londrina. Rev Bioét 2002; 10(1): 8595.

29. Prado MM, Garrafa V. A bioética na formação em Odontologia: importância para uma prática consciente e crítica. Comum Ciênc Saude 2006; 17(4): 26374.

30. Figueiredo AM, Garrafa V, Portillo JAC. Ensino da bioética na área das ciências da saúde no Brasil: estudo de revisão sistemática. INTERthesis 2008; $5(2): 47-72$.

31. Ferreira HM, Ramos LH. Diretrizes curriculares para o ensino da ética na graduação em enfermagem. Acta Paul Enferm 2006; 19(3): 328-31.

32. Brasil. Conselho Nacional de Educação. Câmara de Educação Superior. Resolução no 4/2001. Diário Oficial da União. Brasília, 9 de novembro de 2001. Seção 1, p.38.

33. Zanatta JM, Boemer MR. Bioética: uma análise sobre sua inserção nos cursos de graduação em enfermagem em uma região do Estado de São Paulo. Bioethikos 2007; 1(2): 63-9.

34. Oliveira GB, Guaiumi TJ, Cipullo JP. Avaliação do ensino de bioética nas faculdades de medicina do Estado de São Paulo. Arq Ciênc Saude 2008; 15(3): 125-31.

35. Almeida M, Bitencourt AGV, Neves NMBC, Neves FBCS, Lordelo MR, Lemos KM, Nuñez GR, Barbetta MC, Athanazio RA, Nery-Filho A. Conhecimento e interesse em ética médica e bioética na graduação médica. Rev Bras Educ Med 2008; 32(4): 437-44.

36. Puplaksis NV, Silva MMP, Nobile R, Ramos DLP. A disciplina de bioética na Faculdade de Odontologia da Universidade de São Paulo. Rev Latinoam de Bioet 2010; 10(2): 68-75.

37. Finkler, M. Formação ética em Odontologia: realidades e desafios. [Tese] Pós-graduação em Odontologia, área de concentração de Odontologia em Saúde Coletiva, Universidade Federal de Santa Catarina, Florianópolis, 2009, 259p.

38. Martínez MM, Estrada MRB, Bara FE. La universidad como espacio de aprendizaje ético. Rev Iberoamericana de Educação. 2002; 29: 14-43.

39. Garrafa V. Radiografia bioética de um país - Brasil. Acta Bioethica. 2000; 4(1): 171-3. 
40. Figueiredo AM. Evolution of the teaching of bioethics in graduate education in Brazil. Rev Redbioética/Unesco. 2011; 1(3): 36-45.

41. Editorial. Rev Bioét 2012; 20(1): 7-8.

42. Maluf F, Garrafa V. O termo de consentimento livre e esclarecido nas pesquisas com seres humanos: um estudo de caso. Rev Bioét 2011; 19(3): 725-39.

43. Schramm FR. A pesquisa bioética no Brasil entre o antigo e o novo. Cadernos Adenauer, ano III, n.1, 2002, p.87-101.

44. Garrafa V, Pyrrho M. Bases epistemológicas e políticas da bioética de intervenção. In: Moysés ST, Kriger L, Moysés SJ (cords.). Saude Bucal das Famílias - Trabalhando com evidências. São Paulo: Artes Médicas, 2008, p.298-308.

45. Pessini L, Barchifontaine CP. Uma radiografia da bioética no Brasil: pioneiros, programas educacionais e institucionais e perspectivas. In: Pessini L, Barchifontaine CP (orgs.). Bioética na Ibero-América: histórias e perspectivas. São Paulo: Loyola, 2007, p.99-122.

46. Pessini L, Barchifontaine CP, Prado MM. Bioética no Brasil: produções científicas e perspectivas. In: Anjos MF, Siqueira JE (orgs.). Bioética no Brasil. Aparecida, SP: Ideias \& Letras; São Paulo: Soc Bras Bioética, 2007, p.213-235.

47. Garrafa V, Pessini L. Apresentação. In: Garrafa V, Pessini L (orgs.). Bioética: poder e injustiça. São Paulo: Loyola, 2003, p.11-16.

48. Grisard N. Ética médica e bioética: a disciplina em falta na graduação médica. Rev Bioét 2002; 10(1): 97-114.

49. Declaração Universal sobre Bioética e Direitos Humanos. Brasília: Cátedra UNESCO de Bioética; $2005 . \quad$ http://www.sbbioetica.org.br/wpcontent/uploads/2011/11/TEXTODADUBDH.pdf. Acessado em 27/02/2013.

50. Carvalho M. 8 Congresso Brasileiro de Bioética. Um evento, duas faces. Radis 2009; 88:28-33.

51. D’Ávila RL. O Conselho Federal de Medicina e o ensino da ética e bioética. Rev Bioét 2003; 11(2):51-6.

52. Figueiredo AM. O ensino da bioética na pós-graduação stricto sensu, na área de Ciências da Saúde, no Brasil. Rev Bras Pós Graduação 2011; 8(15): $139-61$.

53. Lenoir N. Promover o ensino de Bioética no mundo. Rev Bioét 1996; 4(1): 65-70. 
54. Pires JR, Shimizu HE. Ética, bioética e educação. Rev Tempus Actas de Saúde Coletiva 2013; v. 7, 191-204.

55. Silva PF. Ensino de bioética no ensino médio - reflexões e desafios para a formação de professores de ciências e biologia. Rev Bras Bioética 2010; 6(14):98-114.

56. Azevedo EES. Ensino de bioética: um desafio transdisciplinar. Interface 1998; 2(2): 127-37.

57. Garrafa V. Multi-inter-transdisciplinaridade, complexidade e totalidade concreta em bioética. In: Garrafa V, Kottow M, Saada A (orgs.). Bases conceituais da Bioética - enfoque latino-americano. São Paulo: Editora Gaia; 2006, p.73-85.

58. Nicolescu B. Um novo tipo de conhecimento: transdisciplinaridade. In: Nicolescu B (org.) Educação e transdisciplinaridade. Brasília: Unesco, 2000, p.10.

59. Yamada KN, Diniz NM. Ética em enfermagem: de um ensino com enfoque deontológico para uma aprendizagem baseada na pedagogia da problematização. O Mundo da Saude 2005; 29(3): 425-8.

60. Rupaya CRG. Conocimientos de ética y bioética del odontólogo en el ámbito de la actividad docente. Rev Latinoam de Bioet 2009; 9(1): 70-5.

61. Gomes JC. O atual ensino da ética para profissionais de saúde. Rev Bioét 1996; 4(1): 53-64.

62. Figueiredo AM. Perfil acadêmico dos professores de bioética nos cursos de pós-graduação no Brasil. Rev Bras Educ Med 2011; 35(2): 163-70.

63. Guerra MM. A disciplina bioética. Rev Bras Bioética 2007; 3(2): 157-69.

64. Vieira PSPG, Neves NMBC. Ética médica e bioética no curso médico sob o olhar dos docentes e discentes. O Mundo da Saude 2009; 33(1): 21-5.

65. Rego S. A formação ética dos médicos: saindo da adolescência com a vida (dos outros) nas mãos. Rio de Janeiro: Fiocruz; 2003. 183 p.

66. Junqueira CR, Silva PMT, Junqueira SR, Ramos DLP. O ensino de bioética: avaliação discente por meio de fóruns de discussão na Internet. Acta Bioethica 2012; 18(1): 93-100.

67. Rego S, Gomes AP, Siqueira-Batista R. Bioética e humanização como temas transversais na formação médica. Rev Bras Educ Med 2008; 32(4): 48291.

68. Meira AR, Cunha MMS. O ensino da ética médica em nível de graduação nas faculdades de medicina do Brasil. Rev Bras Educ Med 1994; 18(1): 7-10. 
69. Zoboli ELCP, Sartório NA. Bioética e enfermagem: uma interface no cuidado. O Mundo da Saude 2006; 30(6): 382-97.

70. Carvalho FT, Muller MC, Ramos MC. Ensino à distância: uma proposta de ampliação do estudo em bioética. Jorn Bras Doenças Sex Transm 2005; 17(3): 211-4.

71. Picheth FS. O ensino da ética médica baseado em solução de problemas. [dissertação]. Curitiba: Faculdade de Educação, PUC-PR; 2000, 185p.

72. Amorim KPC, Araújo EM. Formação ética e humana no curso de medicina da UFRN: uma análise crítica. Rev Bras Educ Médica 2013; 37(1): 138-48.

73. Siqueira JE. O ensino da bioética no curso de Medicina. Rev Bioét 2003; 11(2): 33-42.

74. Odom JG. The status of dental ethics instruction. Journal Dental Education 1988; 52(6): 306-8.

75. Camargo MCVZA. O ensino da ética médica e o horizonte da bioética. Rev Bioét 1996; 4(1): 47-51.

76. Germano RM. A evolução do ensino da ética para enfermeiros. Rev Bioét 1996; 4(1): 79-86.

77. Stern DT, Cohen JJ, Bruder A, Packer B, Sole A. Teaching humanism. Perspec Biol Med 2008; 51:495-507.

78. Kottow MH. Enseñanza de la bioética: una sínteses. Rev Bras Educ Med 2009; 33(4): 658-63.

79. Serodio AMB, Almeida JAM. Os elementos constitutivos da formação éticomoral do estudante de medicina: uma visão docente. Rev Bioethikos 2008; 2(1): 65-72.

80. Correa FJL. Enseñar bioética: como transmitir conocimientos, actitudes y valores. Acta Bioethica 2008; 14(1): 11-7.

81. Oliveira Filho EC. Reforma Universitária: Plano Nacional de Pós-Graduação 2005-2010. In: Parcerias estratégicas: seminários estratégicos. Seminários temáticos para a $3^{a}$ Conferência Nacional de Ciência, Tecnologia e Inovação. Brasília,DF: Centro de Gestão e Estudos Estratégicos (CGEE); jun 2005, n.20, parte I, p.35-52.

82. Barchifontaine CP. Perspectivas da bioética na América Latina e 0 pioneirismo no ensino de bioética no Centro Universitário São Camilo, SP. O Mundo da Saude 2005; 29(3): 392-401.

83. Oliveira MLC. Comitês de Ética em Pesquisa no Brasil: um estudo das representações sociais. Brasília: Editora Universa, 2004. 
84. Gomes ASO, Rodrigues DLN, Sertão VS, Porto D. Ensino em bioética: breve análise da primeira década do Curso de Especialização da Cátedra Unesco de Bioétiva da UnB. Rev Bras Bioética 2009; 5(1-4):82-105.

85. Garrafa V, Porto D. Intervention bioethics: a proposal for peripheral countries in a context of power and injustice. Bioethics 2003; 17(5-6): 399-416.

86. Rudio FV. Introdução ao projeto de pesquisa científica. Petrópolis: Vozes; 2000.

87. Minayo MCS. O desafio do conhecimento. Pesquisa qualitativa em saúde. 14르. Ed. São Paulo: Hucitec Editora; 2014, 407 p.

88. Minayo MCS. (org.). Pesquisa social: teoria, método e criatividade. 20ㄹ Ed. Petrópolis: Vozes; 2002.

89. Pope $\mathrm{C}$, Mays N. Pesquisa qualitativa na atenção à saúde. $3^{\underline{a}}$ ed., Porto Alegre, Artmed, 2009, 172p.

90. Bardin L. Análise de conteúdo. Lisboa: Edições 70; 1977.

91. Brasil. Conselho Nacional de Saúde. Resolução no 466/2012, de 12 de dezembro de 2012. Diário Oficial da União № 12, de 13 de junho de 2013, Seção 1, pág. 59.

92. Garrafa V. El programa de posgrado en bioética de la Universidad de Brasilia. In.: Vidal SM (Ed.) La educación en bioética en América Latina y el Caribe: experiencias realizadas y desafíos futuros. Uruguay: Unesco, 2012, p.343-51.

93. Garrafa V. O novo conceito de bioética. In: Garrafa V, Kottow MH, Saada A (Orgs). Bases conceituais da bioética - enfoque latinoamericano. São Paulo: Gaia, 2006, p.9-15.

94. Schramm FR. A bioética, seu desenvolvimento e importância para as ciências da vida e da saúde. Rev Bras Cancerologia 2002; 48(4): 609-15.

95. Garrafa V, Diniz D, Guilhem DB. Bioethical language and its dialects and idiolects. Cad Saúde Pública 1999; 15(1): 35-42.

96. Hossne WS, Albuquerque MC, Goldim JR. Nascimento e desenvolvimento da Bioética no Brasil. In.: Anjos MF, Siqueira JE (orgs.). Bioética no Brasil: tendências e perspectivas. Aparecida, SP: Ideias e Letras; São Paulo: Soc Bras Bioética, 2007, p.143-60.

97. Siqueira JE, Porto D, Fortes PAC. Linhas temáticas da Bioética no Brasil. Brasil. In.: Anjos MF, Siqueira JE (orgs.). Bioética no Brasil: tendências e perspectivas. Aparecida, SP: Ideias e Letras; São Paulo: Soc Bras Bioética, 2007, p.161-84. 
98. Garrafa V. La bioética en Brasil: de aparición tardía pero bien encaminada. In.: Vidal SM (Ed.) La educación en bioética en América Latina y el Caribe: experiencias realizadas y desafíos futuros. Uruguay: Unesco, 2012, p.179-94.

99. Moysés ST, Moysés SJ, Kriger L, Schimitt EJ. Humanizando a educação em odontologia. Rev da ABENO, 2003; 3(1):58-64.

100. Bugarin Jr JG. Banco de tecidos músculosesqueléticos no Brasil - análise à luz da bioética e da biossegurança. [Tese]. Brasília: Faculdade de Ciências da Saude, UnB; 2007.

101. Schimidt L.La bioética como eje transversal de la formación de postgrado en las ciências de la salud en Venezuela. Rev Bioethikos 2008; 2(1):10-24 .

102. Tealdi JC. Para uma declaración universal de bioética y derechos humanos: uma visión de América Latina. Rev Bras Bioética 2005; 1(1):7-17.

103. Organização para a Educação, a Ciência e a Cultura das Nações Unidas Unesco. Bioethics Core Curriculum, section 1: syllabus - Ethics Education Programme. Unesco: Paris, 2008.

104. Organização para a Educação, a Ciência e a Cultura das Nações Unidas Unesco. Bioethics Core Curriculum, section 2: study material - Ethics Education Programme. Unesco: Paris, 2008.

105. Rupaya CRG. Inclusión de la ética y bioética en la formación de pre y posgrado del cirujano-dentista em Perú. Acta Bioethica 2008, 14(1): 74-7.

106. Siqueira JE. Educação bioética para profissionais de saúde. Rev Bioethikos. 2012; 6(1): 66-77.

107. Koerich MS, Erdmann AL, Rosa VL. A formação ética: desafiando a prática educativa. Bioethikos 2010; 4(4) 395-401.

108. Rego S, Rosito MMB, Yamada KN. Didática, formação de professores e ensino em Bioética. In.: Anjos MF, Siqueira JE (orgs.). Bioética no Brasil: tendências e perspectivas. Aparecida, SP: Ideias e Letras; São Paulo: Soc Bras Bioética, 2007, p.129-42.

109. Vidal S. Una propuesta educativa de bioética para América Latina. Programa de educación permanente en Bioética. Redbioética Unesco. In: RuizValdepeñas BH, Moya FB (Eds.). Educar en Bioética al profesional de Ciencias de la Salud. Una perspectiva internacional. Madrid: Fundación Tejerina; 2010, p.121-57.

110. Outomuro D. Fundamentación de la enseñanza de la bioética en medicina. Acta Bioethica 2008; 14(1): 19-29.

111. Amorim KPC. O cuidado de si para o cuidado do outro. Rev Bioethikós 2013; 7(4): 437-41. 
112. Novaes MRCG, Novaes LCG, Guilhem D, Lolas F, Silveira C, Guiotti M. Inserção dos temas de humanidades e ética em currículo médico integrado em escola pública no Distrito Federal, Brasil. Acta Bioethica 2009; 15(2): 202-11.

113. Fortes PAC. O ensino da bioética e a experiência no campo da saúde pública. O mundo da saúde 2005; 29(3): 429-31.

114. Organização para a Educação, a Ciência e a Cultura das Nações Unidas Unesco. Bioethics Cases Study. Rushap, Unesco: Bangok, 2010. Disponível em: http://www.unescobkk.org/rushap/ethicseducationcorecurriculum/. Acesso em 16 de dezembro de 2014.

115. Organização para a Educação, a Ciência e a Cultura das Nações Unidas Unesco. Casebook on human dignity and human rigths, Bioethics Core Curriculum Casebook Series, no 1, Unesco, Paris, 2011.

116. Organização para a Educação, a Ciência e a Cultura das Nações Unidas Unesco. Casebook on Benefit and Harm, Bioethics Core Curriculum Casebook Series, ํㅡㄹ, Unesco, Paris, 2011.

117. Sané P. Aplicación de la declaración universal sobre bioética y derechos humanos. Rev Bras Bioética 2006; 2(4):437-42.

118. Saada A. La Declaración Universal sobre Bioética y Derechos Humanos ampliación democrática para una sociedad más justa. Rev Bras Bioética 2006b; 2(4):413-22.

119. Garrafa V. Apresentação - Um novo conceito de bioética. In: Garrafa V, Kottow M, Saada A (Orgs). São Paulo, Editora Gaia/Unesco. 2006, p. 09-16.

120. Barbosa S.N. A participação brasileira na construção da Declaração Universal sobre Bioética e Direitos Humanos da Unesco. Rev Bras Bioética 2006; 2(4):423-36.

121. Maluf F, Garrafa V. O Core Curriculum da Unesco como base para formação em bioética. Rev Bras Educ Med 2015, (No prelo).

122. Segre M. Ensino da bioética lato sensu. Rev Bioét 2003; 11(2): 57-60. 
ANEXOS 


\title{
Anexo 1 - Resolução CNE/CES no 01 de 08 de junho de 2007
}

\author{
MINISTÉRIO DA EDUCAÇÃO \\ CONSELHO NACIONAL DE EDUCAÇ̃̃O \\ CÂMARA DE EDUCAÇÃO SUPERIOR
}

\section{RESOLUÇÃO N ${ }^{\circ} 1$, DE 8 DE JUNHO DE 2007 (๗)}

Estabelece normas para o funcionamento de cursos de pósgraduação lato sensu, em nível de especialização.

O Presidente da Câmara de Educação Superior do Conselho Nacional de Educação, no uso de suas atribuições legais, tendo em vista o disposto nos arts. $9^{\circ}$, inciso VII e 44, inciso III, da Lei $\mathrm{n}^{\circ}$ 9.394, de 20 de dezembro de 1996, e com fundamento no Parecer $\mathrm{CNE} / \mathrm{CES} \mathrm{n}^{\circ}$ 263/2006, homologado por Despacho do Senhor Ministro da Educação em 18 de maio de 2007, publicado no DOU de 21 de maio de 2007, resolve:

Art. $1^{\circ}$ Os cursos de pós-graduação lato sensu oferecidos por instituições de educação superior devidamente credenciadas independem de autorização, reconhecimento $e$ renovação de reconhecimento, e devem atender ao disposto nesta Resolução.

$\S 1^{\circ}$ Incluem-se na categoria de curso de pós-graduação lato sensu aqueles cuja equivalência se ajuste aos termos desta Resolução.

$\S 2^{\circ}$ Excluem-se desta Resolução os cursos de pós-graduação denominados de aperfeiçoamento e outros.

$\S 3^{\circ}$ Os cursos de pós-graduação lato sensu são abertos a candidatos diplomados em cursos de graduação ou demais cursos superiores e que atendam às exigências das instituições de ensino.

$\S 4^{\circ}$ As instituições especialmente credenciadas para atuar nesse nível educacional poderão ofertar cursos de especialização, única e exclusivamente, na área do saber e no endereço definidos no ato de seu credenciamento, atendido ao disposto nesta Resolução.

Art. $2^{\circ}$ Os cursos de pós-graduação lato sensu, por área, ficam sujeitos à avaliação dos órgãos competentes a ser efetuada por ocasião do recredenciamento da instituição.

Art. $3^{\circ}$ As instituições que ofereçam cursos de pós-graduação lato sensu deverão fornecer informações referentes a esses cursos, sempre que solicitadas pelo órgão coordenador do Censo do Ensino Superior, nos prazos e demais condições estabelecidos.

Art. $4^{\circ} \mathrm{O}$ corpo docente de cursos de pós-graduação lato sensu, em nível de especialização, deverá ser constituído por professores especialistas ou de reconhecida capacidade técnico-profissional, sendo que $50 \%$ (cinqüenta por cento) destes, pelo menos, deverão apresentar titulação de mestre ou de doutor obtido em programa de pós-graduação stricto sensu reconhecido pelo Ministério da Educação.

Art. $5^{\circ} \mathrm{Os}$ cursos de pós-graduação lato sensu, em nível de especialização, têm duração mínima de 360 (trezentas e sessenta) horas, nestas não computado o tempo de estudo individual ou em grupo, sem assistência docente, e o reservado, obrigatoriamente, para elaboração individual de monografia ou trabalho de conclusão de curso.

Art. $6^{\circ}$ Os cursos de pós-graduação lato sensu a distância somente poderão ser oferecidos por instituições credenciadas pela União, conforme o disposto no $\S 1^{\circ}$ do art. 80 da Lei $\mathrm{n}^{\circ}$ 9.394, de 20 de dezembro de 1996.

(†) Resolução CNE/CES 1/2007. Diário Oficial da União, Brasília, 8 de junho de 2007, Seção 1, pág. 9.

Alterada pela Resolução CNE/CES $n^{\circ} 5$, de 25 de setembro de 2008 , que estabelece normas para o credenciamento especial de Instituições não Educacionais para oferta de cursos de especialização. 
Anexo 2 - Instrumento para coleta de dados

Universidade de Brasília

Faculdade de Ciências da Saúde

Programa de Pós-Graduação em Ciências da Saúde

Informações sobre a pesquisa:

Título: "Perfil dos Cursos de Pós-Graduação Lato-Sensu em Bioética no Brasil". Pesquisador: Fabiano Maluf

Orientador: Prof. Dr. Volnei Garrafa

\section{I - Perfil do entrevistado}

1. Gênero: Masculino ; Feminino

2. Idade: anos.

3. Formação profissional:

4. Tempo de profissão:

até 5 anos ; 6 a 10 anos ;11 a 20 anos

mais de 20 anos

5. Formação em Bioética? Sim ; Não

Especificar qual:

6. Formação acadêmica: Pós-graduação:

Especialização: sim Mestrado: sim não - área:

Doutorado: sim ; não ; não - área: - área:

7. Há quanto tempo trabalha com Bioética?

Até 5 anos ; 6 a 10 anos ;11 a 20 anos mais de 20 anos 


\section{II - Roteiro para entrevista}

\section{Categoria temática 1 - o perfil acadêmico dos cursos}

1. Qual o marco referencial adotado para a condução do curso e quais os objetivos do conteúdo programático?

Busca-se com esta pergunta verificar se o curso oferecido prioriza os valores humanitários (o desenvolvimento moral) e a capacidade de reflexão e autocrítica dos profissionais.

2. Quais as correntes/teorias éticas desenvolvidas no curso? Qual a sua análise a respeito do desenvolvimento de teorias bioéticas brasileiras no contexto mundial?

Analisar se o curso enfatiza o referencial bioético principialista ou se aborda a bioética em sua pluralidade de referenciais teóricos e campos de reflexão, discutindo os conflitos e problemas de saúde e da prática profissional em sua interface com a ética.

3. Qual o conteúdo adequado de um currículo de Bioética? Um currículo mínimo é possível?

Analisar se o conteúdo abordado é suficiente para capacitar profissionais ativos para questionar e argumentar na sua prática profissional.

4. Quais os métodos de ensino-aprendizagem e de avaliação empregados na maioria das disciplinas do curso?

Verificar se há alguma inovação ao método tradicional de "transmissão" de conteúdos e do sistema de avaliação do estudante e se a interatividade é valorizada.

5. O corpo docente possui formação acadêmica em bioética? Qual a formação acadêmica predominante do corpo docente?

Identificar a área de atuação dos professores e a carência ou não de bioeticistas no meio acadêmico.

\section{Categoria temática 2 - a formação profissional em bioética}

6. Qual o perfil dos alunos/profissionais que procuram o curso de especialização em Bioética?

Identificar qual área predomina e que tipo de carências são mais relatadas pelos profissionais que procuram estes cursos..

7. Como a Bioética pode contribuir para a aproximação entre teoria e prática para os estudantes do curso analisado?

Identificar se existem esforços para uma abordagem prática da Bioética com a devida sustentação conceitual/epistemológica, se abordam os dilemas éticos da prática clínica. 
8. Como você avalia a necessidade e importância de um curso de especialização em bioética na formação profissional?

Identificar o que os profissionais que procuram formação em bioética esperam alcançar após a conclusão do curso.

9. Qual o domínio de conhecimento mínimo que o profissional necessita para se tornar um bioeticista?

Identificar quais os conteúdos mais importantes e que conteúdos não podem deixar de ser abordados em um curso de especialização.

10. Qual a sua análise sobre os cursos de especialização em Bioética possuírem um "selo" de certificação de qualidade obtido junto a uma entidade científica (tipo Sociedade Brasileira de Bioética - SBB) ou pela própria Capes/MEC?

Verificar o entendimento e a viabilidade de se propor critérios de qualidade a serem adotados em cursos de bioética. 


\section{Anexo 3 - Termo de Consentimento Livre e Esclarecido}

Universidade de Brasília

Faculdade de Ciências da Saúde

Programa de Pós-graduação em Ciências da Saúde

Informações sobre a pesquisa:

Título: "Perfil dos Cursos de Pós-Graduação lato-sensu em Bioética no Brasil". Pesquisador: Fabiano Maluf

Orientador: Prof. Dr. Volnei Garrafa

Formas de contato: Cátedra Unesco de Bioética: (61) xxxx-1969

Celular: (61) xxxxx-9822

Residência: (61) xxxxx-2683

Prezado(a) Colaborador(a),

Convidamos você para participar, voluntariamente, de uma pesquisa sobre o ensino da bioética nos cursos de pós-graduação lato sensu no Brasil, que resultará na elaboração de Tese de Doutorado a ser apresentada e defendida junto ao curso de Pós-Graduação em Ciências da Saúde, da Faculdade de Ciências da Saúde da Universidade de Brasília.

Serão colhidos depoimentos dos coordenadores responsáveis pelos cursos de especialização em bioética no país, com vistas a obter dados que permitam uma análise sobre temas relacionados aos métodos de ensino-aprendizagem em bioética, periodicidade, perfil e número de alunos, conteúdo programático básico e características docentes, bem como pesquisar seu posicionamento e suas informações com relação a questões de interesse ao ensino da bioética.

Lembramos que sua participação no projeto não é obrigatória, podendo desistir e retirar seu consentimento a qualquer momento. Sua desistência não trará nenhum prejuízo em sua relação com 0 pesquisador nem com a instituição.

Sua participação nesta pesquisa consistirá em responder a uma entrevista do pesquisador, com roteiro pré-estabelecido, enviada por correio eletrônico.

Asseguramos que todos os dados levantados pelo estudo são sigilosos, a eles tendo acesso apenas o pesquisador e o orientador envolvido. Certificamos que não haverá nenhuma forma de identificação 
pessoal durante quaisquer das fases do estudo e, após sua conclusão, em nenhum de seus desdobramentos (apresentações e publicações).

Estando informado(a) e esclarecido(a) sobre o objetivo deste trabalho e disposto a prestar sua colaboração, pedimos o seu consentimento por escrito.

\section{Consentimento do participante da pesquisa:}

$\mathrm{Eu}$, coordenador do curso abaixo assinado(a),

concordo em participar do estudo "PERFIL DOS CURSOS DE PÓSGRADUAÇÃO LATO SENSU EM BIOÉTICA NO BRASIL”, como participante de pesquisa.

Declaro ter sido devidamente informado(a) e esclarecido(a) pelo pesquisador sobre a pesquisa, seus objetivos e procedimentos, assim como sobre os possíveis riscos e benefícios decorrentes de minha participação.

Estou ciente de que poderei retirar meu consentimento a qualquer momento e por qualquer motivo, sem que eu seja prejudicado ou penalizado de qualquer forma.

Fui informado pelo pesquisador que o produto final do estudo consiste em uma Tese de Doutorado, que será apresentada e defendida junto a uma Banca Examinadora, de acordo com as normas do Curso de Pós-Graduação mencionado.

Por fim, concordo com a utilização dos dados obtidos através de minha participação, para quaisquer outras apresentações e elaborações de trabalhos científicos a serem publicados, tendo sido assegurado de que em nenhuma delas ocorrerá qualquer forma de identificação da minha pessoa.

Brasília, de de 2014. 


\title{
Anexo 4 - Parecer de aprovação do Comitê de Ética em Pesquisa
}

\author{
1 \\ Universidade de Brasilia \\ Faculdade de Ciéncias da Saúde \\ Comitê de Ética em Pesquisa - CEP/FS

\section{PROCESSO DE ANÁLISE DE PROJETO DE PESOUSA}

Título do Projeto: "Perfil dos cursos de Pós-graduaçăo lato sensu em Bioética no Brasil"

Pesquisadora Responsárel: Fabiano Maluf

Data de Entrada: $18 / 10 / 2013$

CAAE: $23454413.7 .0000,4030$

Com base na Resoluçăo 466/12, do CNS/MS, que regulamenta a ética $\mathrm{em}$ pesquisa com sems himanos, o Comitê ds: F́tica em Prsuuisa com Seres Humanus da Faculda:e de Ciências da Sajde da Universidade de 13rasilia, após análise dos aspectos éticos e do contexto téenico-cientffico, resolveu APROYAR o projeto intitulado "Perfil dos cursos de Pós-graduaçẫo lato sensu cm Bioética no Brasil", na $3^{2}$ reuniāo ordinária realizala no dia 09 de abril de 2014 .

O pesquisador (a) responsável fica, desde jä, notificado (a) da obrigatoriedade da apresentação de um relatório semes:ral e relctótio final sucinto e objeivo sobre o desenvolvimento do Projeto, no prazo de 1 (un) ano a contar da presente data presente.

Brasília, 09 de julho de 2014.

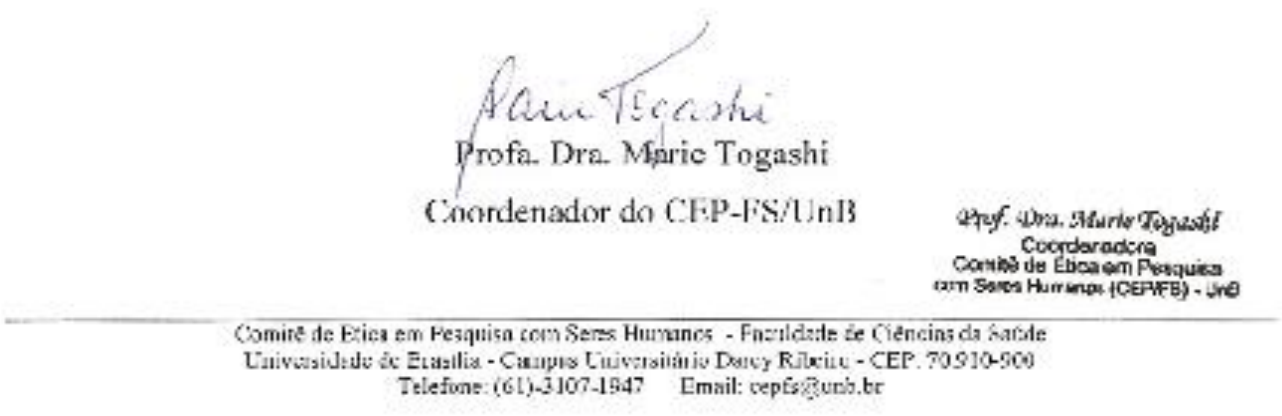




\title{
Anexo 5 - Resolução CNE/CES n 02 de 12 de fevereiro de 2014
}

\author{
MINISTÉRIO DA EDUCAC̣ÃO \\ CONSELHO NACIONAL DE EDUCAÇ̃̃O \\ CÂMARA DE EDUCAÇÃO SUPERIOR \\ RESOLUCุÃO N*2, DE 12 DE FEVEREIRO DE $2014^{(*)}$
}

Institui o cadastro nacional de oferta de cursos de pós-graduação lato sensu (especialização) das instituições credenciadas no Sistema Federal de Ensino.

O Presidente da Câmara de Educação Superior do Conselho Nacional de Educação, no uso de suas atribuições legais, com fundamento no art. $9^{\circ}, \S 2^{\circ}$, alínea " $\mathrm{h}$ ", da Lei $\mathrm{n}^{\circ} 4.024$, de 20 de dezembro de 1961, com a redação dada pela Lei $\mathrm{n}^{\circ} 9.131$, de 24 de novembro de 1995 , tendo em vista o art. $9^{\circ}$, VII da Lei $n^{\circ} 9.394$, de 20 de dezembro de 1996 , e considerando o que consta do Parecer CNE/CES n ${ }^{\circ} 266 / 2013$, homologado por Despacho do Senhor Ministro de Estado da Educação, publicado no DOU em 31/1/2014, resolve:

Art. $1^{\circ}$ Fica instituído o cadastro nacional de cursos de pós-graduação lato sensu (especialização) oferecidos nas modalidades presencial e a distância por instituições credenciadas no Sistema Federal de Ensino.

Parágrafo único. Farão parte do cadastro referido no caput, pelo menos, as seguintes informações sobre cada curso oferecido a partir do ano de 2012:

I - título;

II - carga horária;

III - modalidade da oferta presencial ou a distância;

IV - periodicidade da oferta (regular ou eventual);

$\mathrm{V}$ - local de oferta;

VI - número de vagas;

VII - nome do coordenador;

VIII - número de egressos;

IX - dados sobre o corpo docente.

Art. $2^{\circ}$ Caberá à Secretaria de Regulação e Supervisão da Educação Superior do Ministério da Educação (SERES/MEC):

I - tomar as providências necessárias para adaptação do sistema e-MEC para recepcionar informações relativas ao cadastro nacional nos termos do Art. $1^{\circ}$;

II - estabelecer prazo para cumprimento, pelas instituições de educação superior, das exigências impostas pela presente Resolução, bem como a sistemática de atualização e coleta futura de dados;

III - baixar orientações complementares à presente Resolução para orientar operacionalmente as instituições de educação superior quanto à inscrição de seus cursos no cadastro nacional referido no Art. $1^{\circ}$.

Art. $3^{\circ}$ Findo o prazo estabelecido pela SERES/MEC para o cadastramento dos cursos de pós-graduação lato sensu (especialização), serão consideradas irregulares todas as ofertas não inscritas no cadastro nacional referido no Art. $1^{\circ}$.

Art. $4^{\circ}$ Recomenda-se ao Ministério da Educação que inclua a coleta de dados acerca da oferta dos cursos de pós-graduação lato sensu (especialização) pelas instituições credenciadas no Sistema Federal de Ensino no âmbito do Censo da Educação Superior.

Art. $5^{\circ}$ Esta Resolução entrará em vigor na data de sua publicação, revogandose as disposições contránias.

\section{GILBERTO GONÇALVES GARCIA}

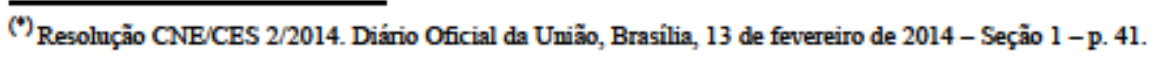

